Portland State University

PDXScholar

9-11-1979

\title{
Copper Toxicity and Extracellular Release in Selenastrum Capricornutum
}

Michael Edwin Darling

Portland State University

Follow this and additional works at: https://pdxscholar.library.pdx.edu/open_access_etds

Part of the Environmental Sciences Commons

Let us know how access to this document benefits you.

\section{Recommended Citation}

Darling, Michael Edwin, "Copper Toxicity and Extracellular Release in Selenastrum Capricornutum" (1979). Dissertations and Theses. Paper 839.

https://doi.org/10.15760/etd.839

This Dissertation is brought to you for free and open access. It has been accepted for inclusion in Dissertations and Theses by an authorized administrator of PDXScholar. Please contact us if we can make this document more accessible: pdxscholar@pdx.edu. 


\section{COPPER TOXICITY AND EXTRACELLLUIAR RELEASE IN \\ Selenastrum capricornutum}

by

Michael Edwin Darling

A dissertation submitted in partial fulfillment of the requirements for the degree of

DOCTOR OF PHILOSOPHY

in

ENVIRONMENTAL SCIENCES AND RESOURCES: BIOLOGY

Portland State University

1979 
TO THE OFFICE OF GFADUATE STUDIES AND RESEARCH:

The members of the Committes approve the dissertation of

Mlichael Edwin Darling presented September 11, 1979.

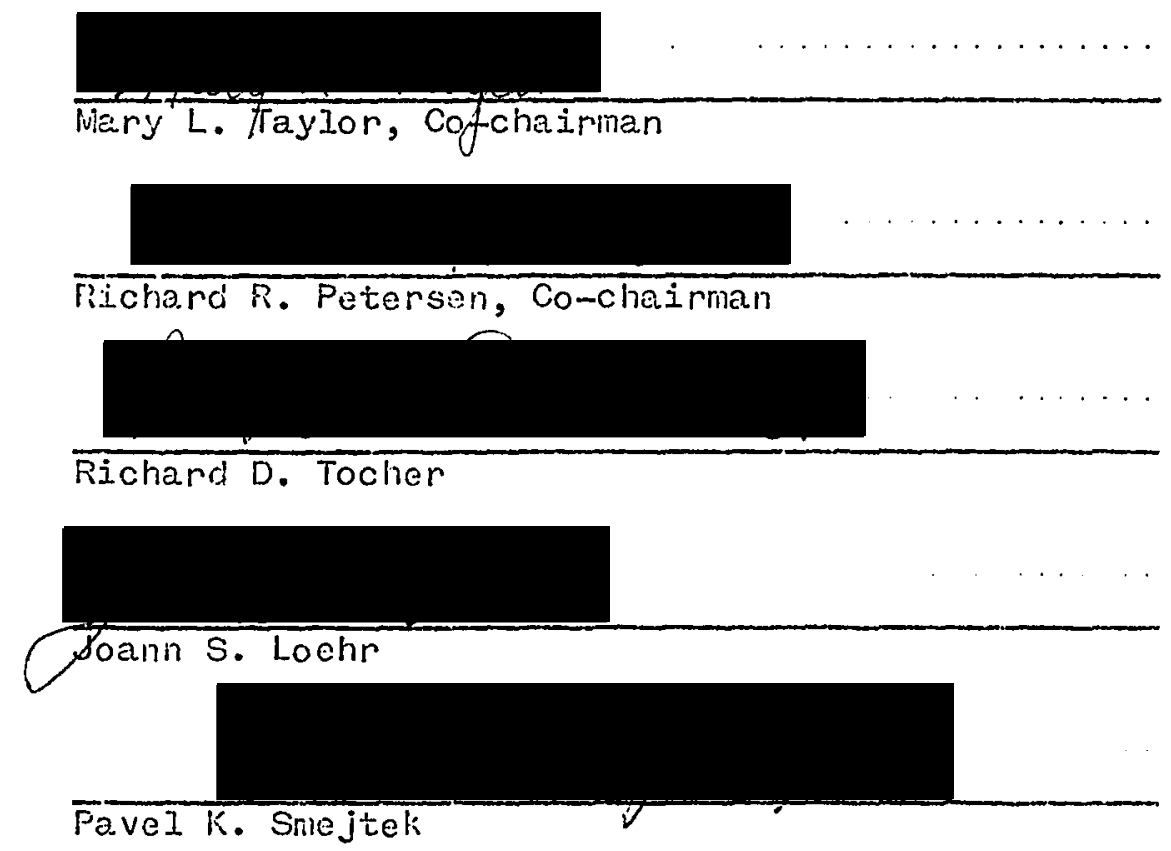

APPROVED:

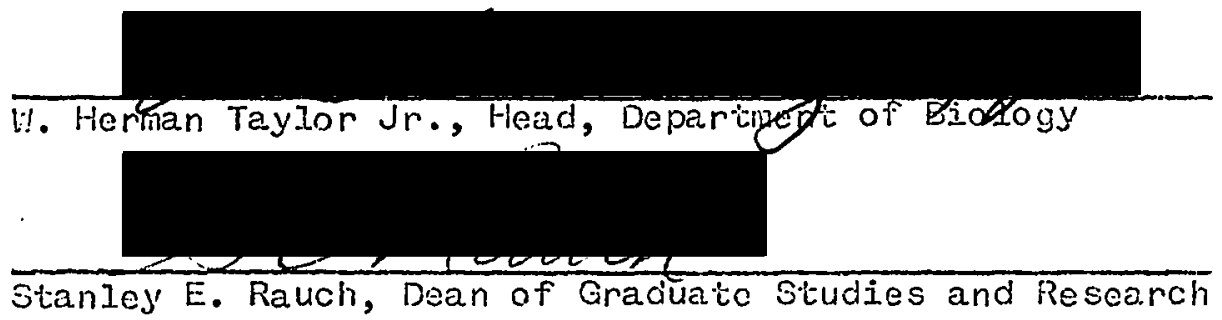


AN ABSTRACT OF THE DISGERTATION OF Gi.chae.l Edwin Darling for the Doctor of Philosophy in Environmental Sciences and Resources:

Eiology presented september 11, 1979.

Title: Copper Toxicity and Extracellular Releasc in Selonastrum capricornutum.

APPROVED BY MEMEERS OF THE DISSERTATION COMHITTEE:

Mary L.I Taylor, Co-chaiman

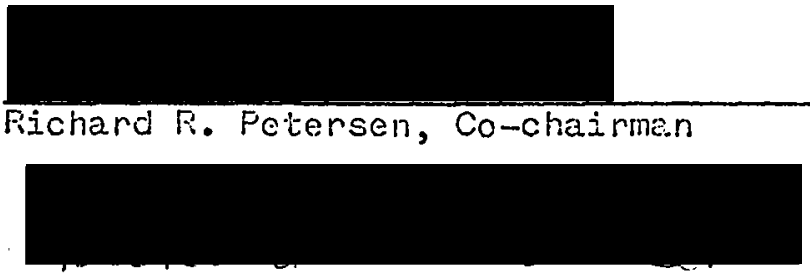

Fichard D. Tocher

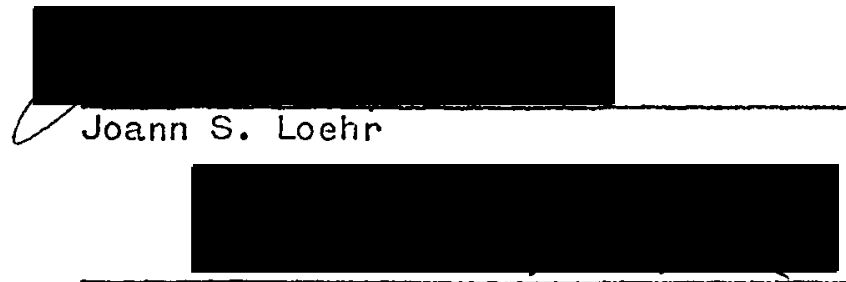

Pavel K. Sinejtek 
Copper toxicity was investjgated using the green alga, Selenastrum capricornutum. Two major areas were investigated: the forms of copper Which are toxic to growth of the alga and ractors that can change the concentration of free copper, $\mathrm{Cu}^{2+}(\mathrm{ag})$, in the growth medium during the logarithmic growth of the organism.

This research has shown that $\underline{S}$. capricornutum is sensitive to the free copper ion, $\mathrm{Cu}^{2+}(\mathrm{aq})$, irrespective of the total copper concentration. Results indicate the following linear relationship: Growth rate constant $=(0.54 \mathrm{pCu})-3.6$

A correlation coefficient of 0.92 was obtained within the $\mathrm{pCu}$ range of 10 to 7 . The $\mathrm{pcu}$ in each culture was buffered with eihylenediaminetetraacetic acid (EDTA) or nitrilotriacetic acid (NTA). Some cultures showed a $T$ day lag period regardiess of the copper concentration. Growth inhibition due to copper vas reversible at all copper concentrations tested.

Copper adaptation by the alga, changes in ionic strength during the growth of the alga in batch culture, and uptake of EDTA or copper by the alga were factors which were not accounted for in the calculation of free copper concentrations. All were found to have only a slight effect on this free copper concentration. However, extracellular release of organic products has a small but significant effect on ionic copper concentrations. The amount of carbon excreted was $5.5 \times 10^{-14}\left( \pm 3.1 \times 10^{-14}\right)$ moles per cell. This is about two percent of the total amount of carbon fixed per cell. A 7 day culture

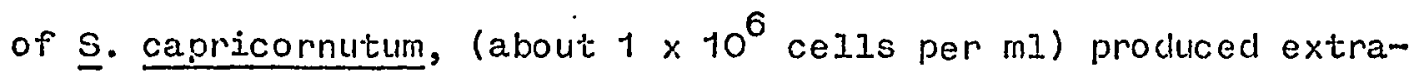
cellular organic products that can complex $2 \times 10^{-7}$ M copper as 
determined from copper titrations using a copper selective electrode. This represents 1.2 times more copper complexed than that due to inorganic nutrients present in the medium. The conditional stability constant for these extracellular organic products is $10^{5.55}$ at $\mathrm{pH}$ 5.0. The equilibrium for this complexation is as follows:

$$
\mathrm{Cu}^{2+}+\mathrm{H}_{x} \mathrm{~L} \rightleftarrows \mathrm{CuL}+\mathrm{xH}^{+}
$$

This conditionel stobility constant is relatively weak when compared With that of coppenEDTA or copper-NTA complexes, but stronger than copper-fulvic acid complexes. Fulvic acid is native to natural waters. It was also apparent that the stoichionetry of complexation was one mole of metal ion complexed per mole of extracellular organic product. There vas no increase in copper complexing capacity of products rezeased by celis grown in the presence of copper concentra-tions that reduce the growth rate by one-half. Concentrated extracellular organic products were separated by thin layer chromatography. Eleven to thinteen products were recovered. The same products were isolated from cultures grown in the presence of an inhibiting amount of copper as were isolated from cultures grown with no excess copper. The copper complexing capacity of the separated fractions from the original medium, accounting for concentration effects, ranged from $1 \times 10^{-10}$ to $2 \times 10^{-8} \mathrm{molar}$. 
I would like to thank Richard Petersen (Cochairman), who provided much time and great assistance from the inilial development of the project to its completion and in whose laboratory the research for this dissertation was conducted.

I would like to express my gratitude to Mary Taylor (Cochairman) for her support and continual guidance throughout this research as Well as providing equipment and laboratory space for this project. Her interest in this research and assistance in the preparation of this dissertation contributed immensely to its completion.

I an very grateful to other advisors on my dissertation comittee; Joann Loehr, Richard Tocher and Pavel Sinejtek who provided many helpful discussions, suggestions, constructive criticism, continuous encouragement, and assistance during the course of this research as well as the review and organization of the drafts of this dissertation. I would like to thank Helmer Colonia-Roque for his assistance in several copper bioassay experiments.

I am gratefuI to AI Levinson who provided equipment and laboratory facilities for the culturing of algae in carboy quantities.

I would also Iike to express my appreciation to E. Michael Perdue for his valuable advice and assistance during the course of this research. 


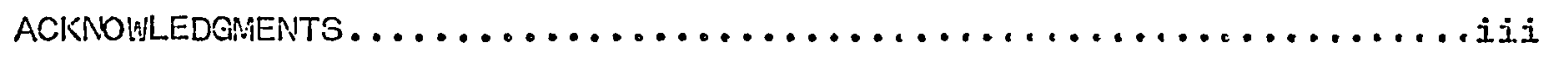

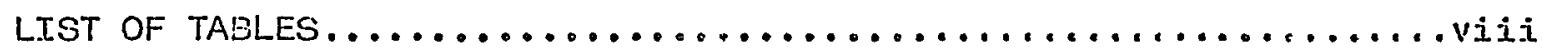

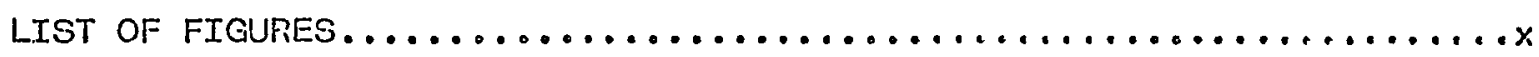

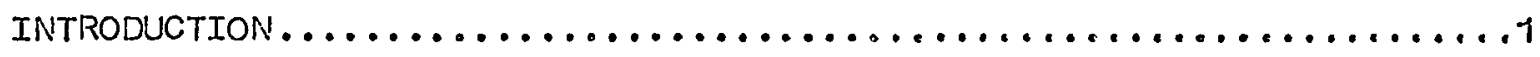

I. The amount of copper present in the aquaicic

environment................................

II. The forms of copper which is toxic to

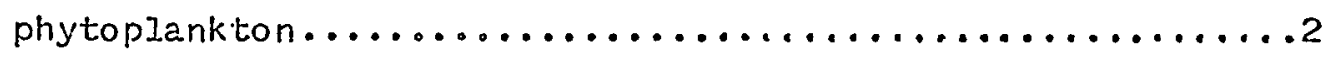

III. Rationale for studying the effect of ionic

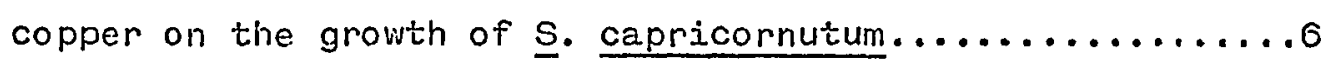

IV. Proposed Research...........................

MATERIALS AND METHODS. ..............................

I. The test organism............................ to

II. CuIture medium and preparation of the stock

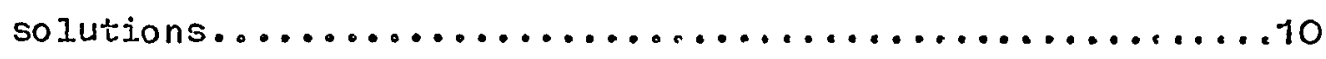

III. The copper bioassay..........................12

IV. Measurement of ${ }^{14} \mathrm{CO}_{2}$ uptake and release of

excreted carbon as labeled extracellular

products.................................13 
V. Concentration of extraceliular products........15

VI. Total capacity and percent efficiency of XAD-8

on extracellular products.............17

VII. Separation of extraceliular products..........18

VIII. A potentiometric neasurement of copper

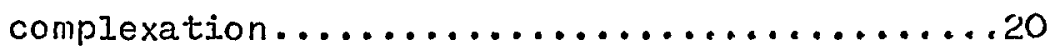

IX. Viability of $\underline{S}$. capricornutum from copper

bioassays........................24

$x$. Measurement of ionic strength in modified EPA

medium plus $8.00 \times 10^{-7}$ : EDTA during the

four day growtin of $\Xi$. capricornuturn........?4

$X I$. The determination of growth rate versus $p C u$

during transfer...................25

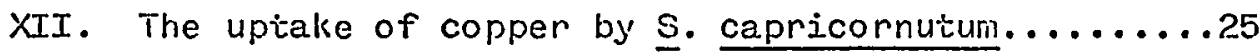

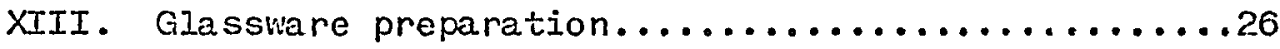

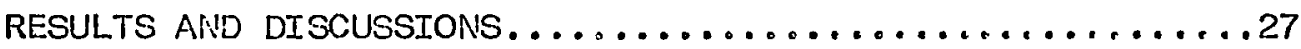

I. Dependence of copper toxicity of pCu..........27

Former studies prior to present research.....27

Growth of S. capricornutum on copper

bioassay medium ..................29

Affect of copper concentration on growth

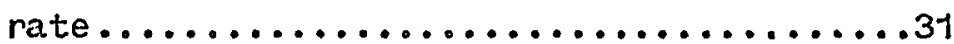

The Reversibility of copper toxicity........35 
A comparison of $\mathrm{Cu}^{2+}(\mathrm{aq})$ sensitivity of

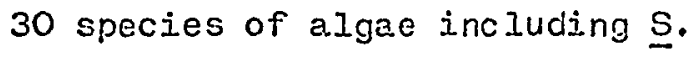
capricornuturn.......................

II. Production of extracellular carbon...........42

III. The concentration of extracellular products by use of Amberlite $X A D-8$ rosin..........47

IV. Thin layer chromatography (TLC) separation of concentrated products....................50

V. Copper complexing capacities of algal. filtrates

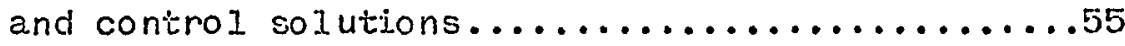

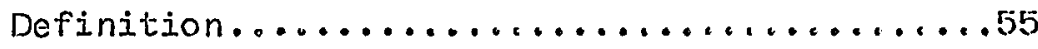

Method and theory...................... 55

The copper complexing capacity of

extracellular products from unconcentrated algal filtrates............60

The copper complexing capacity of concentrated extracellular products.........663

The copper complexing capacity of separated products......................65

VI. Determination of conditional sibability constants

for concentrated extracellular products......67

VII. Effect of copper uptake on $\mathrm{Cu}^{2+}(\mathrm{aq}) \ldots \ldots \ldots \ldots$. . . .

VIII. The effect of other factors on $\mathrm{Cu}^{2+}(\mathrm{aq}) \ldots \ldots \ldots \ldots 78$ 
SUMARY AND CONCLUSTONG .....................86 REFERENCES..................................90 APPENDIX A................................... APPENDIX

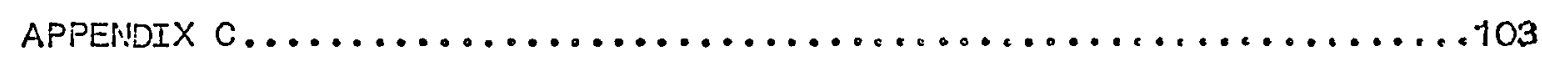
APPENDIX D..................................... APPENDIX E........................................... APPENDIX F..................................112 


\section{LIST OF TABLES}

TABLE

PAGE

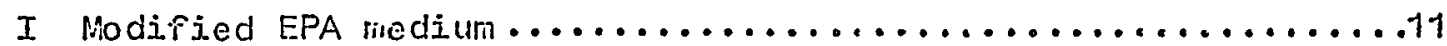

II Research establishing a Iinear relationship between

$p C u$ and the growth rate $\ldots \ldots \ldots \ldots \ldots \ldots \ldots \ldots \ldots$

III Copper viability study $\ldots \ldots \ldots \ldots \ldots \ldots \ldots \ldots \ldots \ldots \ldots \ldots \ldots \ldots . \ldots . \ldots$

IV Gerloff's medium $\ldots \ldots \ldots \ldots \ldots \ldots \ldots \ldots \ldots \ldots \ldots \ldots \ldots \ldots$

$\checkmark$ A comparison of $\mathrm{pCu}^{*}$ sensitivity in 30 species of

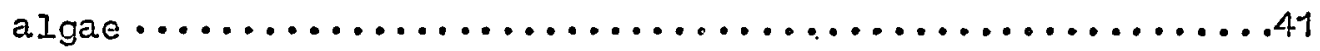

VI Extracellular release in algae as a percent of

total assimilated carbon ....................45

VII The Efficiency of XAD-B resin ....................49

VIII Detection of separated fraction of extracellular

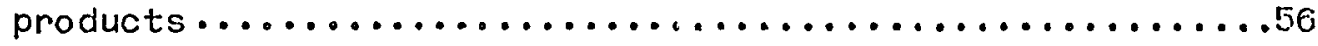

IX The copper complexing capacity of modified EPA medium

containing various EDTA concentrations..............

$x$ The copper complexing capacities, conditional stability

constants, and average molecular weights of

concentrated extracellular products from $\underline{\mathbf{S}}$.

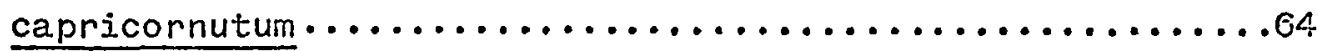

XI The copper complexing capacity of Separated fractions......66

XII The effect of copper uptake on $\mathrm{pCu}^{*}$ after three days

of growth in EPA medium $\left(8.00 \times 10^{-7}\right.$ M EDTA $\ldots \ldots \ldots \ldots . . . .78$ 
XIII Nutrient uptake experiments: The variation of cations and ionic strength over a four day growth period........83 XIV Nutrient uptake experiment: The variation of anions over a four day growth period..................84 


\section{LIST OF FIGURES}

\section{Figure}

PAGE

1. A comparison between the two parameters of growth;

hemacytometer cell counts and absorbance

at $680 n m \ldots \ldots \ldots \ldots \ldots \ldots \ldots \ldots \ldots \ldots \ldots \ldots \ldots \ldots \ldots$

2. A typical calibration curve for a copper sulfide

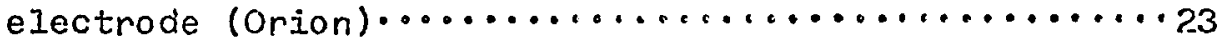

3. Copper bioassay growth curve for Selenastrum

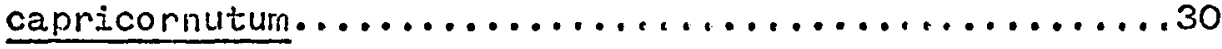

4. Copper bioassay experiment with Selenastrum

capricornutum: specific growth rate versus

the log of total copper concentration..............32

5. Copper bioassay experiment with Selenastrum

capricornutum: the specific growth rate versus pcu....34

6. ${ }^{14} \mathrm{CO}_{2}$ uptake by Selenastrum capricornutum...........43

7. The holdiac capacity of XAD-8 resin for ${ }^{14} \mathrm{CO}_{2}$

labeled extracellular product from Selenastrum

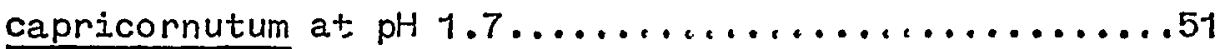

8. A 2-dimensional thin layer chromatogram of concentrated

algal products from Selenastrum capricornutum grown

in the absence of copper..................53

9. A 2-dimensional thin layer chromatogran of concentrated

algal products from Selenastrum capricornuturi

initially grown with $50 \mu \mathrm{g} / 1$ copper.............54 
10. Deternination of the copper complexing capacity from

a copper titration of $1.13 \times 10^{.-4}$ M NTA...........58

11. Determination of the copper complexing capacity from

a copper titration of a solution containing

extracellular paroducts from $\leqq$. capricornutum.......59

12. A typical scatchard plot from a solution containing

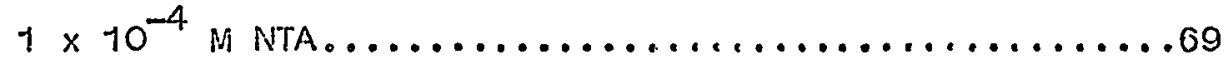

13. A Scatchard plot of a solution containing extracellular

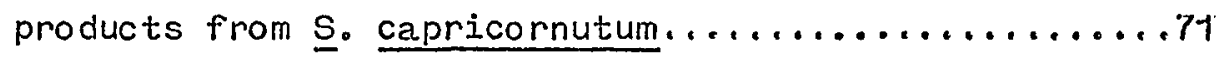

14. The conditional stability constants for NTA as a

function of $p H \ldots \ldots \ldots \ldots \ldots \ldots \ldots \ldots \ldots \ldots \ldots \ldots$

15: The conditional stability constants from concentrated extracellular products from S. capricornutum as

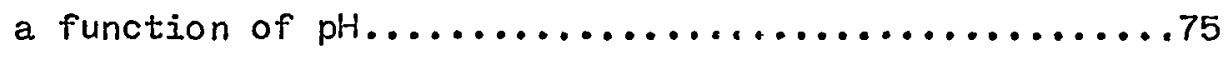

16. A comparison of the conditional stability constants

for several copper-ligand complexes..............77

17. The effect of subculturing $\ldots \ldots \ldots \ldots \ldots \ldots \ldots \ldots \ldots \ldots$ 


\section{INTRODUCTION}

\section{THE AROUNT OF COPPER PRESENT IN THE AQUATIC EIVIROMIENTT}

The wicespread distribution of copper j.n natural waters is of particular importance because j.t is extremely toxic to phytoplankton. For example, copper naturally present in seavater can be toxic to some species of marine algae (Steemann-litielsen and Vium-Anciersen, 1970; Barber, 1973). Total copper concentrations between 0.4 and $12.3 \mu$ per liter occur off the African coastitine around the Canary Islands, (Riley and Taylor, 1971), while concentrations of 4 to 13 Hg per liter occur off the coast of Florida (Alexander and Corcoran, 1967).

Copper mining has a pronounced effect on copper concentrations in nearby rivers and lakes. The copper released by mining may enter lakes and rivers in surface drainage or as atmospheric particulate fallout from smelters. Rainwater collected one mile from a smelter located in the Sudbury, Ontario mining area contained $122 \mu \mathrm{g}$ per Iiter copper (Stokes and Hutchinson, 1970), even at a 12 mile distance there was $21 \mathrm{\mu g}$ per liter copper in the rainwater. Numerous small "softwater" lakes exist around Sudbury in which copper concentrations up to $80 \mu g$ per liter have been reported. The River Hale which drains the abandoned copper mines in Corntwal, England contains s copper concentration of $120 \mu \mathrm{g}$ per liter while upstream from this dränage site concentrations are less than $2 \mu$ per liter (Foster, $1977)$ 
Copper sulfate has been used worldwicie as an algicide for several ciecades and applied in concentrations as high as $15 \mathrm{mg}$ copper per Iiter. Its irtroduction into reservoirs, (Button and Hostetter, 1977), into seawater to control red tides, (Rounsefell and Evans, 1958), or into irrigation projects, (Eariley, 1976) has been commonplace.

II. THE FORIM OF COPPER WHICH IS TOXIC TO PHYTOPLANKTON

Most studies of copper toxicity to phytoplankton have involved the comparison of relative copper sensitivity of several species of algae in one standard medium, (Thomas et a.1., 1977; Ma.tonoy and Palmer, 1956; Erickson, 1972). However, by the use of ciffierent defined media it has been shown that toxicity is not a function of total copper, (Fitzgerald and Faust, 1963; Fitzgerald, 1964; GteemannNielsen and Vium-Andersen, 1970; Stokes and Hutchinson, 1976). These authors concluded that organic complexing agents such as nitrilotriacetic acid (NTA), ethylenediarinetetraacetic acid (EDTA), tris(hydroxymethyl) aminomethane (TRIS) or citric acid, which are added to increase the iron solubility and complex copper diminish copper toxicity. Uncomplexed copper was hypothesized to be the toxic form to algae by Steemann-Nielsen and Vium-Andersen (1970) who noted that organic matter usually present in surface sealvater is absent in deeper water. In the absence of organic matter, it would be expected that the ionic form of copper would be present in higher concentration. Thus, they concluded that phytoplankton cannot grow in freshly updwelled deep water, because this organic free water could contain ionic copper concentrations of 1 to $2 \mu \mathrm{g}$ per liter copper which 
is poisonous to many phytoplankton.

Ionic copper may be measured by anodic stripping voltametry, solvent and resin extraction, copper selective electrodes, or theoretical calculations using computer prograns. Although anocic stripping voltametry has been used by several researchers in the measurement of ionic copper, the plating out of copper from the solution may perturb the weak copper complexes in the system. As yet there is no proven anodic stripping procedure to distinguish between ionic copper and soluble bound copper at concentrations present in natural Waters (Gachter et al., 1973; Shuman and Woodward Jr., 1973).

Solvent extraction has been used to measure ionic copper concentrations (Kennish, 1978). The method extracts only a few percent of the bound copper thus perturbing the system very jitite. However, development of the best working conditions near neutral pH (as would occur in natural water samples) is sij.I at the formative stage. At present only simple metal-ligand systens at an acidic pH have been successfully measured. Similar problens arise for methods which use ion exchange resins as an excraction procedure for copper. Again the best working conditions for natural waters have not been devised (Cemble et al., 1970).

Copper selective electrodes have been developed for measuring the activity of the ionic copper. The detection limit of copper seiective electrodes is in the range of $10^{-8}$ to $10^{-9}$ in and Iinear response of potential in volts versus the log of ionic copper concentration is attained down to $3 \times 10^{-7} \mathrm{~N}$ (Elaedel and Dinlviddie, 1974). 
The ionic copper concentration in natural waters has been measured widely by this procedure (Stiff, 1971; Ramamoorthy and Kushner, 1975; Kimball, 1973; Cheam and Gamble, 1974). The most serious problem with this method is the detection limit, as many species of algae are inhibited at ionic copper concentrations below this detection Iimit.

At present, the only satisfactory method for estimating the concentration of low levels of ionic copper is an indirect calculation. Ionic copper concentrations can be calculated if all inorganic and organic anion and cation concentrations are known as well as all relevant acid dissociation constants, formation constants and solubility products. A data base is available in the following references (Silién and Martel1, 1964; 1971) and calculations for relatively simple systems which contain copper complexes provide useful information (Sylva, 1975; Sunda, 1975; Gardiner, 1975). In the last few years, computer programs have been devised which give a thermodynamic calculation of ionic copper in complex systems involving many ligands and metals. Two programs in wide use are MINEQL (Westall et al., 1976) and REDEQL2 (MCDuff and Morel, 1973). Morel and Morgan (1972) explain the mechanics of calculating activities of chemical species from these equilibrium models. Calculated copper activity is referred to as $\mathrm{pCu}^{*}$ to distinguish it from experimentally determined $\mathrm{pCu}$.

A calculated value of ionic copper has the primary advantage of estimating a concentration which may be far below the detection limit of analytical methods. These calculations provide a predictable 
model for copper bioassays. The disadvantage with a computer calculation of ionic copper concentration is that the predictions are only as accurate as the assumed equilibrium constants used in the data base. There is often a fair disagreement in values between the same constant measured by different techniques. As discussed later in this dissertation, one or more of the acid dissociation constants for NTA used in MINEQL are in question. Other problems With a computer calculation of ionic copper concentration are the lack of kinetic considerations when ionic activities are calculated and the lack of applicability to undefined media. such as natural aquatic systems.

In the last few years these computer programs or sinilar calculations have been employed to establish that ionic copper, rather than total copper, is the toxic form to aquatic organisms (Morel et al., 1978; Anderson and Morel, 1978; Andrew et al., 1976; Sunda and Guiliard, 1976). Copper bioassays have been performed using several species of algae and a crustacean. The negative log of the copper ion concentration ( $\mathrm{pCu}^{*}$ ) was calculated for a defined medium (Morel et al., 1978) and a direct correlation between the growth rate and $\mathrm{pCu}$ " was apparent. In addition, these results established that copper-TRIS, copper-EDTA or copper-NTA complexes are not toxic to algae (Anderson and Morel, 1978; Sunda and Guillard, 1976). Andrew et a.l. (1976) have also shown that soluble copper phosphate and copper carbonate complexes are not toxic to the crustacean, Daphnia magna.. 
III. PATIONALE FOR STUDYING THE EFFECT OF IONIC COPPER ON THE GROWTH OF Selenastrum capricornutum

The aim of this research was to examine factors (such as pH changes in the medium, total copper, EDTA or nutrient uptake by the algae, and extracellular release of algal products), which might change the ionic copper concentration during the period of logarithmic growth of the organism. The possibility of genetic mutation favoring copper tolerance was also investigated as another factor which could change copper toxicity to the organism. Other than changes in pH of the medium, these factors have not been extensively investigated in algae by other investigators. Copper bioassays were perforned in order to test the hypothesis that this test organism is sensitive to ionic copper rather than other complexed forms of the metal and also to determine the range of ionic copper $\left(\mathrm{Cu}^{2+}\right)$ sensitivity.

Selenastrum capricornutum was selected as the bioassay organism because it is unicellular, nonmotile and quite small (an average of 5 to 10 microns in length). These properties facilitate reproducibie viable counts. This organism also has been used widely in metal toxicity and nutrient deficiency studies (Clesceri et al., 1973; Miller et al., 1974; Bartlett et al., 1973; Miller et al., 1975; Heiss and Helms, 1971; Miller et al., 1976; Toerien and fiuang, 1973; Goldman et al., 1974; Chiaudani and Vighi, 1977). The major focus of this research was directed toward the study 
of copper complexation on extracellular products released by $\underline{\underline{S}}$. capricornutum. Algae excrete a wide range of extroceliular products (Hellebust, 1974; Fogg, 1971, 1966: 1962: Aaronson et al., 1971; Gocke, 1970; Weinmann, 1970) and there is some evidence that algal lysates can complex copper. Cell digests containing hycirolyzed amino acids from Anabaena cylindrica and ChIorella pyrenoidosa, a blue-green and green algae respectively, were found to reduce the copper toxicity to algae when added to a medium prior to inoculation (Fogg, 1955; Steemann-ivielsen and Kamp-Nielsen, 1909). Gjbson (1972) a.lso found that copper was less toxic for green and blue-green algae if copper was adcied to the medium after the initiation of algal growth. This indicated the possibility of extracellular excretion by the algae.

Several species of marine phytoplankton have been stressed with Iethal and sublethal copper concentrations (Mandelli, 1969). Subsequent to copper stress there was an immediate copper absorption by the cells. It was demonstrated that arter several minutes there was release of copper back into the medium. The excretion of organic compounds has been proposed by Mandelli (1969) as a mechanism to reduce the stress and Foster (1977) also found evidence of extracellular release. Copper bioassays were performed with two strains of Chlorella vulgaris, one of which is a copper tolerant variety. Both strains exhibited the same growth rate as a function of the amount of copper taken into the cell. Thus, both strains have physioIosically the same tolerance to absorbed copper. However, the metal tolerant strair, possessed larger growth rates than the nontolerant strain under the same conditions of metal stress. It appears that 
the metal tolerant strain may have evolved the ability to produce an extracellular product which can lower the activity of the ionic copper or adaptation by the cell to regulate the uptake of copper against a high external copper gradient.

Copper complexation by algal exudates from several species of algae has been measured using copper selective electrodes (Swallow et al., 1978), since this method can provide direct evidence for excretion of algal products which complex copper. However, only one exucitite from the species, Gleocystis gigas, showed any appreciable copper complexation. Filtrates from cultures of this alga were found to have a copper complexing capacity of $5 \times 10^{-6} \mathrm{M}$ with a conditional stability constant of 1.0 at plt 7.0 (the constant defined in the same nanner as that of this dissertation). Copper complexation from the other algal filtrates was probably underestimated because the copper selective electrode was too insensitive to permit adequate measurement at low ligand concentrations. In addition, the reportediy lower copper complexation of these filtrates is also likely because added iron (at a concentration of $1 \times 10^{-5} \mathrm{M}$ ) competed with copper for complexation sices.

IV. PROPOSED RESEARCH

In the present research, the copper complexing capacities were measured using copper selective electrodes on extraceliular

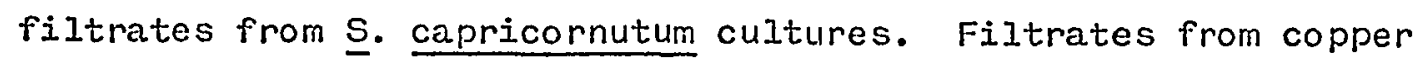
stressed and non-stressed cultures were compared in order to determine 
if extracellular release was initiated at high copper concentrations. The following types of extracellular filtrates were measured: unconcentrated filirates, desalted and concentrated filtrates, and 13 extracellular algal products which had been separated by thin tayer chromatography. In order to show the copper affinity for these excreted products, conditional stability constants (from concentrated and desalted filtrates) were calculated from copper titration data obtained using a ion selective electrode. In addition, molecular weight and copper complexing capacities were also measured for these products.

An evaluation of all of these factors was made in order to . assess whether or not the growth rate of $\underline{S}$. capricornutum would be a good indicator for the concentration of ionic copper. 
MATERIAL AND METHODS

I. THE TEST ORGANISIN

An inoculum of Selenasirum capricornutum was obtained from the EPA (Environnental Protection Agency) at Corvallis, Oregon. Axenic cultures of the alga were prepared using a modified centrifucotion and filtration technique (James, 1971). A sonication step was added between repeated washings. Conical centrifuge tubes $(15 \mathrm{ml}$ ) containing $5 \mathrm{ml}$ of algae were placed in a Branson 12 ultrasonic cleaner for 15 seconds. This presumably removes the bacteria from the cell will of the alga. The final centrifuged algal. syspension was streaked on Plate Count Agar (Taras, 1971) containing EPA mediun, (lteiss and HeIms, 1971). Colonies that were found to be axenic were transferred to $25 \mathrm{ml}$ of EPA medium in $125 \mathrm{ml}$ Erlenmeyer flasks. The cultures were transferred every 4 or 5 days to insure continuous $\log$ phase growth. All experimental cultures were inoculated with cells of S. capricornutum in the logarithmic phase of growth.

II. CULTURE MEDIUM AND PREPARATION OF THE STOCK SOLUTIONS

For mosi work, the standard EPA meditum was modified to vary copper and EDTA a.s Iisted in Table 1. A stock solution of each nutrient was maintained at 1000-fold concentration and stored in $500 \mathrm{ml}$ linear polyethylene bottles at room temperature. For testing the effect of complexing agents (or free metal concentrations) on the growth rate of $\underline{s}$. capricornutum, four modifications of the 
TAELE I

BODIFIED EPA MEDIUI.

COMPONENT*

$\mathrm{NaNO}_{3}$
$\mathrm{~K}_{2} \mathrm{HPO}_{4}$
$\mathrm{NgCl}_{2}$

$\mathrm{MgSO}_{4} \cdot \mathrm{TH}_{2} \mathrm{O}$

$\mathrm{CaCl}_{2} \cdot 2 \mathrm{H}_{2} \mathrm{O}$

$\mathrm{NaHHCO}_{3}$

$\mathrm{FeCl}_{3} \mathrm{O}$

$\mathrm{H}_{3} \mathrm{EO}_{3}$

[inCl 2

$\mathrm{ZnCl}_{2}$

$\mathrm{CoCl}_{2}$

$\mathrm{Na}_{2} \mathrm{HOOO}_{4} \cdot 2 \mathrm{H}_{2} \mathrm{O}$

EDTA or INTA

$\mathrm{CuNO}_{3}$
FINAL CONCENTPATION IN THE GROWTH MEDIUi: (WOLAR)
$2.8 \times 10^{-5}$

$0.0 \times 10^{-6}$

$0.0 \times 10^{-5}$

$5.9 \times 10^{-5}$

$3.0 \times 10^{-5}$

$1.7 \times 10^{-4}$

$5.9 \times 10^{-7}$

$2.2 \times 10^{-6}$

$2.1 \times 10^{-0}$

$2.4 \times 10^{-7}$

$0.0 \times 10^{-9}$

$3.0 \times 10^{-8}$

variable

variable

*-ilallinckrocit, anayltical gracie reagents were used except NTA which was obtained from Eastman Chem. Co. (Analytical grade) and $\mathrm{CukO}_{3}$ (Orion Ionanalyzer cupric Standard).

Q- The forric chloride solutions contained ethylenediamineteiraacetic acid (EDTA) or nitrilotriaceitic acid (WTA) at various concentrations as indicated for a given experiment. 
medium (shown in Table 1) were used: EDTA at $8.06 \times 10^{-7} \mathrm{~m}, 5 \times 10^{-6} \mathrm{~m}$ and $1 \times 10^{-5}$ m or NTA at $1 \times 10^{-6} \mathrm{~m}$. The chelating agents were stored at 1000-fold concentrations in the $\mathrm{FeCl}_{3}$ stock solutions. In this research these synthetic chelating agents are important in controlling the solubility of ferric iron and the ionic copper concentrations.

III. THE COPPER BIOASSAY

Culture medium was prepared from the stock solutions by diluting $1000 \mu \mathrm{I}$ from each stock solution into approximately $500 \mathrm{ml}$ of distilled water in a volumetric flask. The volume was adjusted with distilled water to one liter. After vigorous mixing, 25 ml of medium was transferred with a $25 \mathrm{ml}$ automatic vacuum pipet to specially cleaned glassware (see subsection XIV. of this Material and Mlethods section for cleaning procedures). Ten $\mu$ of copper nitrate, initially dillited in distilled vater, was transferred with a 10 ul pipet to each $25 \mathrm{ml}$ of medium to yield a final concentration of 1.57 to $18.8 \mathrm{x}$ $10^{-7} M$ copper. The Enlenmeyer flasks were closed with cotton stoppers and autoclaved for 20 minutes at $121 \mathrm{C}$. Flasks were placed in a deark cabinet at room temperature for 2 days to allow for the solutions to reach chemical equilibrium. At the start of the third day the axenic algal culture was transierred into each flask to give a final concentration of a thousand cells per $\mathrm{ml}$. These inoculated flasks were then placed on a rotory shaker and oscillated at 120 revolutions 
per minute. The shaker was positioned under a bank of Sylvania fluorescent life-line lights at $1.09 \times 10^{4}$ Iux (measured at culture level). The temperature under the light bank varied from 20 to 25 C. Each 24 hours for 5 to 7 days, thrce parameters were measured in all cultures: (1) cell counts by a hemacytometer, (2) absorbance at $680 \mathrm{~nm}$, and (3) pH of the medium. Cells were counted on an American Optical hemacytometer using a Zeiss phase contrast binocular microscope at $400 \%$. The optical density of cultures was measured using Perkin Elmer cylincirical $50 \mathrm{~mm}$ Spectrosil cuvettes in a ColemanHitachi 124, double bean spectrophotometer. The $\mathrm{pH}$ was measured with a Chemirix combination $\mathrm{pH}$ electrode and Orion Research Ionanalyzer specific ion meter model 404.

Specific growth rates were calculated between days 1 and 2 using the general growth equation found in Appendix A. A plot of absorbance at $680 \mathrm{~nm}$ versus cell number showed a linear relationship in the absorbance range between 0.01 and 0.2 (Fig: 1). The linear relationship can be expressed as follows:

CeII number $=1.93 \times 10^{6}$ (Absorbance $\left.680 \mathrm{~nm}\right)-1.4 \times 10^{4}$

From a comparison of 300 samples a correlation coefficient of 0.88 could be obtained.

IV. MEASUREMENT OF CAREON-14 UPTAKE AND RELEASE OF EXCRETED CARBON AS LABELED EXTRACELLULAR PRODUCTS

$A$ volume of $300 \mathrm{ml}$ of modified EPA medium containing $8.06 \times 10^{-7}$ MEDTA (no copper) was placed in Kimax dissolved oxygen ( $D .0$. ) bottles and inoculated with a $\log$ phase culture of $1.5 \times 10^{7}$ cells 


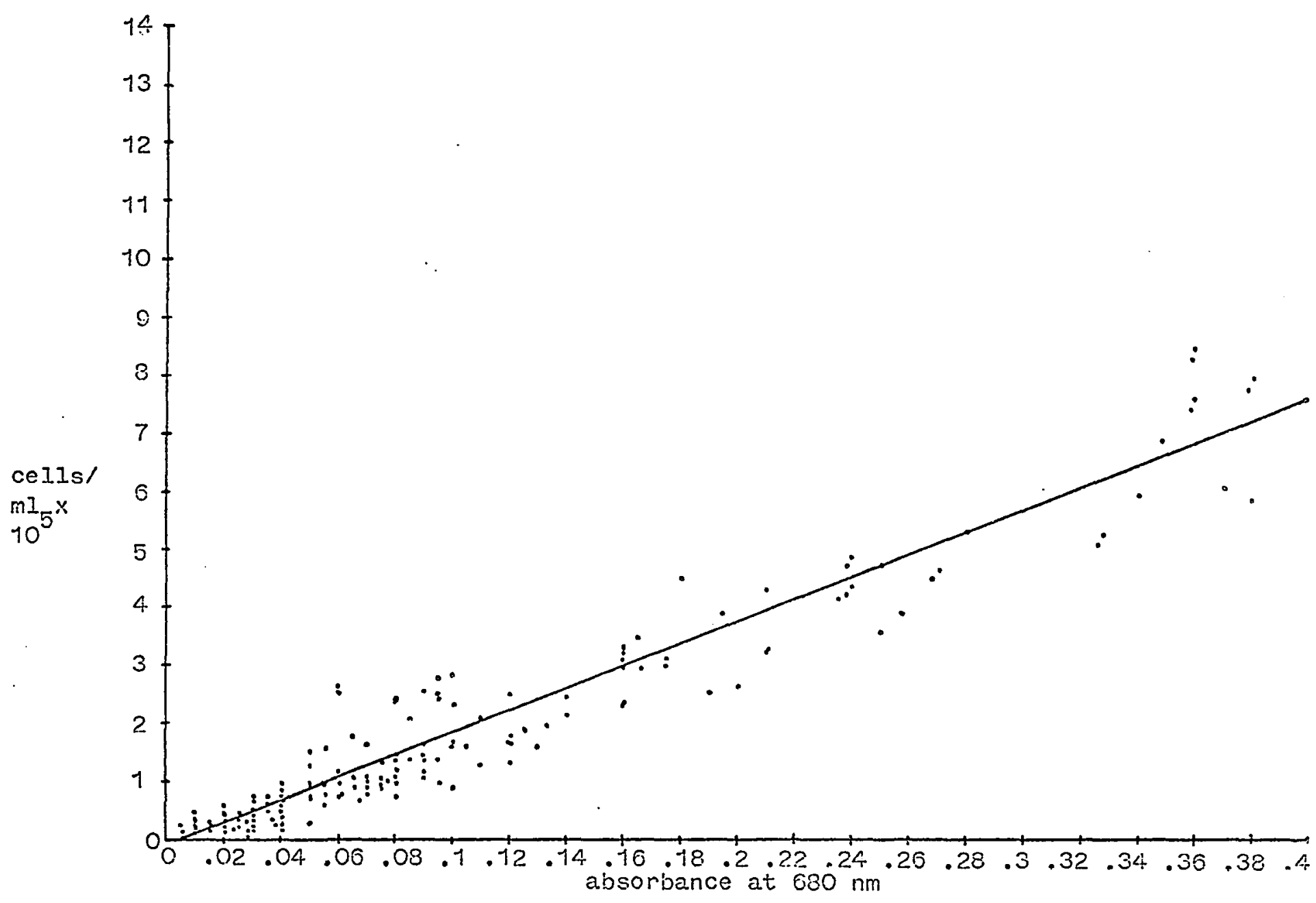

Fig. 1. A comparison between the 2 paraneters of growth; hernacytometer cell counis and absorbance at $580 \mathrm{~nm}$. 
to give $5.0 \times 10^{4}$ celjs per ml. The bottiles werc spiked with 5.0 uCi of $\mathrm{NaH}^{14} \mathrm{CO}_{3}$ and incubated in a water bath, $24 \mathrm{C}$, at $1 \times 10^{4}$ Iux. In order to rule out bacterial contamination and rixation of ${ }^{14} \mathrm{CO}_{2}$ in the dark, D. O. bottles covered with black tape were used as controls and incubated as stated above. The total organic carbon fixed was measured in procedures described below. At various time intervals several bottles were removed and two, $30 \mathrm{ml}$ volumes were collected from each bottle for analysis of carbon-14. The two volumes represent total organic carbon fixed and extracellular carbon released by algal cells. Procedures for both volumes were identical with the exception of an additional step required in the measurement of extracellular carbon. This extra step involvec the removal of the algal pellet fron the volune by centrifigation at room temperature in a Sorvall RC-E2 at $7500 \times \mathrm{g}$ for 10 minutes. Both volumes were acidified by the addition of $0.2 \mathrm{mI}$ of $0.1 \mathrm{M} \mathrm{HCL}$ and aerated for 20 minutes as described by Schindler and Holmgren (1971). For determination of carbon-14 in all samples, $5 \mathrm{mI}$ from each volume and $10 \mathrm{mI}$ of Aquasol-2 (New England Nuclear) were added to scintillation vials. Radioactive disintegrations from these vials were counted in a Nuclear-Chiago Unilux-II Iiquid scintillation counter.

V. CONCENTPATION OF EXTRACELLULAR PRODUCTS

Nine, 16-liter Pyrex carboys containing modified EPA medium with $8.06 \times 10^{-7} \mathrm{M}$ EDTA were inoculated with $\mathrm{S}$. capricornutum at a rinal 
concentration of a thousand cells per mI. Five carboys contained no copper and four carboys contained a concentration of $7.87 \times 10^{-7} \mathrm{~m}$ total copper. This is enough total coppep to depress the growth rate by one-half of the maximum. Once cultures reached the stationary phase of growith ( 3 to $5 \times 10^{6}$ cells per $\mathrm{ml}$ ), they were centrifuged at $8000 \times g$ at $5 \mathrm{C}$ using a Syent-Gyorgyi and Blum KSB-R Continuous flow system connected to a Sorvall RC--2E refrigeraced centrifuge. The algal pellets were freeze dried, weighed and scored at - $20 \mathrm{C}$. The supernatant fluid was clarified by passage through a Millipore prefilter and $0.45 \mu \mathrm{M}$ filter. The filtrates were acidified to $\mathrm{pH}$ 1.7 with nitric acid (Malinckrodt $A R$ ).

Amberlite XAD-8 resin (Rohm and haas) was washed on a filter with 3 to 4 bed volumes of distilled water to remove the sodium bicarbonate in which it was orginally packed. The resin was extracted for 24 hours with methanol (Mallinckrodt Spectr AR) in a Soxhlet extractor. Finally the resin $(150 \mathrm{gm}$ suspended in methanol) was packed in a $2 \mathrm{py} 30 \mathrm{~cm}$ column. .

The supernatant fluid from each set of carboys was washed through the column with a flow rate of 6 (Jiquid phase) bed volumes per hour. After all the supernatant fluid had been filtered through the column, the resin was eluted with 1 bed volume of $0.1 \mathrm{~A} \mathrm{KOH}$ followed by several bed volumes of methanol. The $100-125 \mathrm{ml}$ of elutant fraction was ccliected separately and stored in screw capped Erlenneyer flasks. Ultimately, the eluate from the XAD-8 resin was concentrated by vacuum distillation at $40 \mathrm{C}$. 
VI. TOTAL CAPACITY AND PERCENT EFFTCIENCY OF XAD-8 RESIN OF EXTRACELLULAR PRODUCTS

Methanol extracted XAD-8 resin $(15 \mathrm{gm})$ was packed into a 1.6 by $20 \mathrm{~cm}$ column. A 16 liter carboy of modified EPA medium (containing $8.06 \times 10^{-7} \mathrm{M}$ EDTA and spiked with $15 \mathrm{ml}$ of $5 \mu \mathrm{Ci}$ per $\mathrm{ml} \mathrm{NaH}^{14} \mathrm{CO}_{3}$ ) was inoculated to give 1000 cells per $\mathrm{ml}$ S. capricornutum and the culture was incubated at $7.6 \times 10^{3}$ Iux at room temperature. After 7 days incubation, the supernatant fluid was obtained, acidified and aerated as previously described. Exiracellular products in the supernatant fluid were coricentrated by the $X A D-8$ column and the resulting effiuent was collected in eleven, 1-Iiter fractions. In order to monitor the capacity of the column to concentrate exitracellular prociucts, $5 \mathrm{ml}$ aliquots from each liter of effluent and to $\mathrm{ml}$ of Aquasol-2 were added to scintillation vials. Radioactivity was counted by the liquid scintillation method. The total capacity of the column was calculated from the change in activity from the monicored effluent as compared to the initial unfiltered supernatant fluid.

The column was eluted with one bed volume of $0.1 \mathrm{M} \mathrm{KOH}$ and several bed volumes of methanol. The methanol and KOH eluted fractions were evaporated and diluted to $5 \mathrm{~m}$ Is with distilled water. The activity of these samples were measured by liquid scintillation counting. The percent efficiency of the resin was calculated either as the ratio of activity of the unfiltered supernatant fluid and effluent or as the ratio of the total aciivity from extracted fractions as compared 
to the total calculated activity of unfiltered supernatant fluid.

VII. SEPARATION OF EXTPACELLULAR PRODUCTS

Products were separated by thin layer chromatography (TLC). Uncoated glass TLC plates were cleaned by inmersion in saturated ethanol-KOH solution for one-half hour or longer, then thoroughly rinsed in distilled water in a TLC drying rack and dried in an oven at $105 \mathrm{C}$. The sorkent was silica gel G (E. M. Merk, Ein Reagent). Silica gel $G(30 \mathrm{~g})$ was added to $60 \mathrm{ml}$ of distilled water in a $500 \mathrm{ml}$ corked Erlenmejer Tlask and shaken vigorously for 90 seconds (E. Stah 1, 1959). The mixture was spread over four to five TLC plates $(20 \mathrm{~cm} \times 20 \mathrm{~cm} \times 4.7 \mathrm{~mm}$ ) using a Shandon Southern Unoplane spreader. Two sorbent thicknesses were selected: $0.25 \mathrm{~mm}$ for detection and 1 $\mathrm{mm}$ for preparative use.

Two solvent systems were ultimately selected for separation of the products; (1) ethyl acetate and (2) n-butanol, formic acid, and water $(4: 1: 1 \mathrm{v} / \mathrm{v} / \mathrm{v})$.

For detection work, a two-dimensional chromatogram was determined using ethyl acetate in the first direction, and the n-butanol, formic acid, and water mixture 4:1:1 (v/v/v) in the second direction. The chromatography tank $(25 \times 27 \times 7 \mathrm{~cm})$ was Iined with Whatman No. 1 filter paper to speed equilibration. The concentrated extracellular prodicts $(20 \mu I)$ were applied using a $10 \mu \mathrm{I}$ micropipet and the samples were air dried on the TLC plates. When the solvent front had reached the top of the plate, the plates were removed from the tank and 
air óried.

Detection of spots was accomplished by foun methods (visible, fluoresence, iodine staining and ninhydrin reaction) and after detection the spois were traced onto overlays of plastic. Visible spots were detected by placing the plate on a $11 \times 45 \mathrm{cn}$ fluorescent light tray (Buchler Instruments). Spots which fluoresced under UV light were located by use of a Chromato-wue ultraviolet chamber having long wave UV at $365 \mathrm{~nm}$ and short wave UV at $254 \mathrm{~nm}$. Compounds containing carbon-carbon double bonds were cletected by incubation of the TLC plates in an enclosed chromatography tank containing iodine crystals (MaJlinckrodi U.S. P.); after several minutes the yellow to brown spots were noted. Air was passed gently over the TLC plates for one-half to 1 hour in order to remove the iodine. The last detection system involved the spraying of TLC plates with a ninhydrin

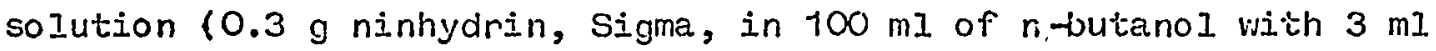
glacial acetic acid). Each plate was then placed in an oven at $105 \mathrm{C}$ for 5 to 10 minutes for color development. Using plastic overlays obtained from the 4 detection systems, $R_{f}$ values were calculated for the separated products.

TLC was also employed in the preparative separation of extracellular products. Concentrated eluates were applied onto silica gei $\circlearrowleft$ TLC plates one inch from the bottom using a 500 ul pipet and the streaks were air dried. Ethyl acetate was used to separate products initially. Products which did not move in the first solvent (ethyl acetate) were scraped from the orgin with a zone 
collector and the products were exiracted from the silica gel with methanol. This methanol extract was concentrated by evaporation of the methanol and then applied to a second plate in the manner mentioned previously. The 3 component solvent systern (n-butanol, formic acid, and water $4: 1: 1, v / v / v)$ was used in this second separation. Finally all detected spots were recovered with the zone collector and the products stored in screw-capped Pyrex test tubes $(9 \times 150 \mathrm{~mm})$ at 4 C.

VIII. POTENTIOMETRIC MEASUREMENT OF COPPER COMPLEXATION

The use of copper ion selective electrodes in determining the stability products for fulvic acid, humic materials, and algal products has been reported (Buffle et al., 1977; Chean and Gamble, 1974; Cheam, 1973; Jasinski et al., 1974; Swallow et al., 1978). Copper ion selective electrodes (Orion model 94-29A) were used to determine copper complexing capacities, conditional stability constants and average nolecular weights for extracellular products from S. capricornutum. Nitrilotriacetic acid was used as a standard ligand solution.

A Radiometer pH meter type pHM $26 \mathrm{C}$ vith an Orion double junction reference electrode (model 00-02-00) was use to measure free copper. The pH was monitored simultareously with the free copper concentration using an Orion digital 112 pit meter connected to a Sargent (3-30070-10) conbination pH glass electrode. The following procedure wes used for titrations. Samples containing $0.1 \mathrm{MKNO}$ to assure 
constant ionic strength were contained in $100 \mathrm{mI}$ polyethylene beakers. The solutions were placed on magnetic stirrers, and $10 \mu l$ volumes of titrant were added. The addition of the titrant did not appreciably change the total volume of the solution during the titration. The solutions were equilibrated for 10 minutes bet: :een each addition (ElaedeI and Diwiddie, 1974).

Three types of titrations were performed: copper, ligand and acid-base titrations. Copper titrations were made in order to determine copper complexing capacities, conditional stability constants, and average molecular weights for ligand solutions at a given pH. Standard $10 \mu \mathrm{I}$ aliquots of copper, prepared by dilution of the stock solution $\left(0.1 \mathrm{M} \mathrm{CuNO}_{3}\right)$ from $1-10$ to $1-10,000$ with distilled water, were added to a solution at a constant phl and total ligand concentration. The copper complexing capacities of unconcentrated, XAD-8 concentrated aIgal filtraces, and purified extracellular products were deternined. In addition, average molecular weights and conditional stability constanis at pH 5.0 and 6.0 were determined (according to theory derived in Appendix E) for XAD-8 concentrated extraceliular products.

Ligand titrations involved the addition of $10 \mu \mathrm{I}$ of concentrated extracellular products to solutions at constanit total copper concentrations. These titrations were maintained at constant $\mathrm{pH}$ and indicate the stoichiometry of copper Iigand complexes (see Appendix E for calcuiations). Conditional stability constants also can be obtained by this method. 
Once the concentration of ligand had been determined, acid-base titrations were made on NTA solutions and concentrated extracellular products in orcier to obtain conditional stabilicy constants over the pH range, 2.0 to 7.0 . These titrations involve addition of a strong acid $\left(\mathrm{HNO}_{3}\right)$ or strong base $(\mathrm{KOH})$ to a solution containing both constant total ligand and copper concentrations.

Ca.Iibration curves were.constructed as standards for $\mathrm{pCu}$ between the range 8.0 to 5.0 . Solutions of $0.1 \mathrm{MNO}$, were used as blanks in copper titrations. Total copper acded is assumed to be uncomplexed and measured as free copper. According to the Nernst equation:

$$
E=E_{0}+R T / n F \log \left(A_{c u}+A_{x}\right)
$$

where $R$ equals the gas constant; $T$, the absolute temperature; $F$, the Faraday; $E_{0}$, the standard potential; $E$, the measured potential; $A_{c u}$, the activity of the ionic copper; $A_{x}$, the activity of the interfering ion $x ; n$, the valence of the copper ion. Theoretically the value of $R T / n F$ for a divalent cation is 29.6 millivolis at $25 \mathrm{C}$. Thus a 10-fold change in the activity of ionic copper produces a 29.5 millivolt change in potential. The experimental response of an electrode is usally less than the theoretical response as seen in Fis. 2. Near the detection limit of $10^{-7}$ in ionic copper, it is evident that the experimental slope drops off sharply. 


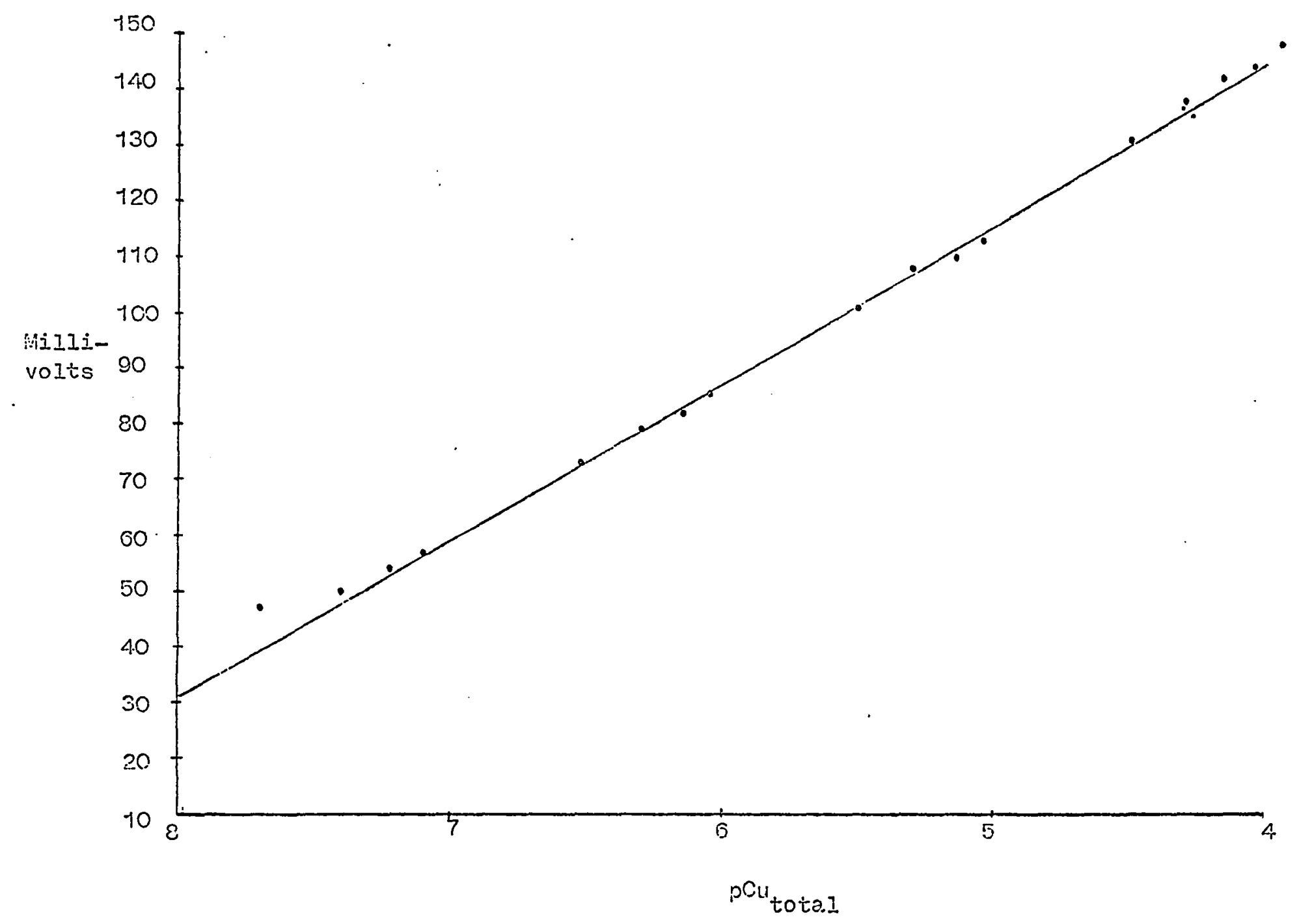

Fig. 2. A typical calibration curve for a copper sulficie electrode (Orion). at a pit of 5.0. Stanciard solutions of $10^{-1}, 10^{-2}, 10^{-3}$, and $10^{-4}$ in Cunio,

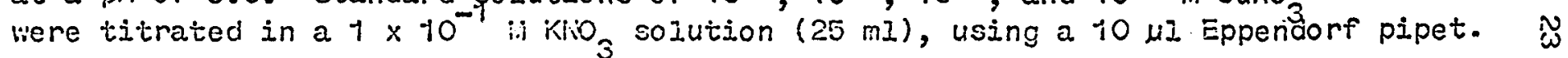


IX. VIAEILITY OF S. CaPRICO rnutum FROH COPPER EIOASSAYS

Selenastrum capricornutum cells grown at copper concentrations between 1.57 to $18.8 \times 10^{-7}$ in copper in modified EPA medium pilus $8.06 \times 10^{-7}$ EDTA were sprayed onto petri dishes containing 15 $g$ per Iiter Difco agar in modified EPA medium plus $8.05 \times 10^{-7} \mathrm{~A}$ EDTA and no copper. The plates were counted for three days using a Zeiss phase contrast microscope at 4.00 magnification. Thirty random fields were counted for each culture and for each field the total number of cells and number of cells undergoing division were recorded. A ratio of dividing cells versus total cells was detemined.

․ MEASUREIENT OF IONIC STRENGTH IN RODIFIED EPA MEDIUM PI.US $8.00 \times 10^{-7}$ M EDTA DURING THE FOUR DAY GROUTTH PERIOD OF $\underline{S}$. capricornutum

Algal cells were grown in a 10-liter pyrex carboy (containing modified EPA medium with $8.06 \times 10^{-7}$ M EDTA without copper), at a final inoculum concentration of one thousand cells per $\mathrm{ml}$. Each day, a one-liter sample was taken from the carboy and centrifuged at $8,000 \times 9$ for 10 minutes at $4 \mathrm{C}$, in a Sorva $11 \mathrm{RC}-32$ refrigerated centrifuge. The supernatant fraction vas concentrated 100-fold by vacuum distillation at $40 \mathrm{C}$ and the concentration of major ions was determined. A Perikin-Elmer 305B atomic absorption spectrophotometer was used for the analysis of the major cations: $\mathrm{K}^{+}, \mathrm{Na}^{++}, \mathrm{Mg}^{++}$ and $\mathrm{Ca}^{++}$. A bariun precipitation method (Shakerin-Sweet, 1979) was 
used for sulfate analysis. Chloride concentrations were measured by titration with mercuric nitrate (Taras, 1971). Nitrate was determined by a cadmium reduction method (Taras, 1971). The ionic strength of the medium (based on the total concentration of the major ions and a 1-100 concentratjon step) was calculated for each day.

XI. THE DETERMINATION OF GROVITH RATE VERSUS pCU DURING TRANSFER

Selenastrum capricornutum cells, grown for 7 days at to ta.l copper concentrations between 1.57 to $18.8 \times 10^{-7} \mathrm{M}$ copper, were transferred to fresh medium containing the same respective copper concentration. Srowth rates were calchlated from cell counts made at day 1 and $2 ;$ this is the same time period in which growth rates Were initially calculated. A comparison of growith rates was made between the initial and transferred cultures grown at each concentration of copper.

XII. THE UPTAKE OF COPPER BY $\underline{\underline{s}}$ capricornutum

Flasks were inoculated with one thousand cells per $\mathrm{mI}$ of $\underline{\mathrm{S}}$. capricornuturn which had been grown on modified EPA medium plus $8.06 \times 10^{-7} \mathrm{M}$ EDTA and either $6.29,7.89,9.44$ or $11.1 \times 10^{-7} \mathrm{it}$ copper. The initial pCu was calculated to be $8.35,7.94,7.39$, and 7.25 . The flasks were incubated at $1.09 \times 10^{4}$ Iux for two days and harvested as previously described. The algal cells viere Iyophilized, weighed and stored in Pyrox bottles at $-20 \mathrm{C}$. The 
cells were thawed, rosuspencied in distilled water to $1 / 25$ th of the orginal volume and the copper content of the celis was analyzed by flameless atomic absorption spectroscopy using an Instrumenta? Laboratory AA/AE spectrophotometer IL 551 with flameless atomizer 455 .

XIII. GLASS:ARE PREPARATION

All glassivare was soaked in a saturated cthanol-tioti solution for one hour or longer, then, thoroughily rinsed in distilled water and finally oven dried at 105 C. Pyrex flasks used in copper bioassay experiments were silanized to minimize copper adsorpition onto inner glass surfaces. Dry Pyrex flasks used in the assay were filled with a 5 percent solution of dichlorodimethylsitane (mollinckrodt OR) diluted in chloroform (Mallinckrocit $A R$ ) $v / v$, and soaked 30 minutes. All flasks were thoroughly rinsed with chloroform, distilled water and air dried. 


\section{RESULTS AND DISCUSSION}

\section{DEPENDENCE OF COPPER TOXICITY ON pCu}

\section{FORMER STUDIES PRIOR TO PRESENT RESEARCH}

Steemann-Nielsen and lium-Andersen (1970) proposed that algae are sensitive exclusively to the uncomplexed copper, $\mathrm{Cu}^{2+}(\mathrm{aq})$. They proposed that the naturally occurring concentration of ionic copper in nutrient-depleted seavater was toxic to the phytoplankton commuility.

To date, several sutdies have indicated a linear relationship of growth rate to the negative log of the copper ion concentration ( $p C u$ ) for a diaton Thalassiosira pseudonana (Sunda and Guillard, 1976), another diatom, Skeletonema costatum (Morel et al., 1978 a green alga, Nannochloris atomus, (Sunda and Guillard, 1976) and a Chrysophyte alga, Monochrysis Iutheri (Sunda and Lewis, 1978). Andrew et al. (1970) extended this hypothesis to an invertabrate, the crustacean, Daphnia magna. Since most algae are sensitive to $\mathrm{pCu}$ far below the detection limit of most instrumental and chemical methods, most of the results were obtained using a calculated value of the negative log of the copper ion concentration $\left(\mathrm{pCu}{ }^{*}\right)$. This calculated value $\left(\mathrm{pCu}^{*}\right)$ in a defined medium can be obtained by the use of computer programs such as MINEQL (WestaII et a.., 1976). Ionic copper has been found to be the toxic form of copper to all aquatic organisms examined to date. 
Sunda and Guillard (1976) monitored the pH of their cultures during a copper bioassay experiment and recalculated pcu* at these measured pH's in order to see if changes in pH had a significant effect on $\mathrm{pCu}^{*}$. The pH of cultures showed a slight efrect on $\mathrm{pCu}^{*}$. In addition the copper content of the cells was analyzed to show copper uptake by cells and the affect on $\mathrm{pCu}$ *. This affect was found to be insignificant.

Anderson and borel (1978) found that chenical equilibrium between copper and EDTA was obtained only after 24. hours. Cultures inoculated before this equilibration time showed proporitional increases in toxicity. On the other hand, copper-TRIS complexes formed almost j.mediately (Ancierson and MoreI, 1978).

Andrew et a1. (1976) deterinined the concentration of copper required to kill one-half of the initial population of Daphnia magna in 24 hours. Their results indicated that while ionic copper is toxic to Daphnia magna, $\mathrm{CuCO}_{3}(\mathrm{aq})$ and $\mathrm{Cu}\left(\mathrm{PO}_{4}\right)^{-}(\mathrm{aq})$ are not. Suncia and Lewis (1978) used a copper ion selective electrode to measure $\mathrm{Cu}^{2+}(\mathrm{aq})$ in the growth meciiuln for the copper bioassay of 1 . Iutheri and found a Iinear relationship between $\mathrm{pCu}$ and the growth rate. A second contribution from this paper is the rinding that phytoplankton are sensitive to $\mathrm{Cu}^{2+}(\mathrm{aq})$ in the presence of naturally occurring river water ligands. All previous studies not only employed calculated pCu":, but used synthetic Ij.gands to buffer $\mathrm{Cu}^{2+-}(\mathrm{aq})$. This work indicates (using a copper eiectrode) that 
these natural copper-ligand complexes are not toxic to aquatic organisms. This paper claimed to obtain 99 percent of the theoretical slope for their calibration curves to a $\mathrm{Cu}^{2+}(\mathrm{aq})$ concentration of $10^{-10} \mathrm{M}$. However, Jasinski et al. (1974) and Johansson and Edstrom (1972) reported a detection limit of $10^{-7}$ w using the same kind of electrode under the best conditions.

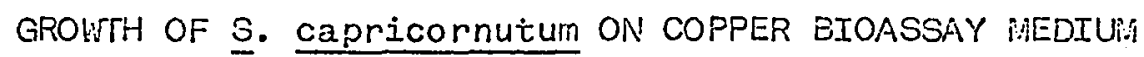

In order to determine if ionic copper is toxic to Selenastrum capricornutum, copper bioassay experiments vere performed using modified EPA nedium (Table 1.). A typical example of a growth curve is represented in Fig. 3. From these resulis a number of observations can be made. First, the modified EPA medium without copper can support a firal population of 4 to $7 \times 10^{6}$ cells per mI. Toerien and liuang (1973) have determined that phosphate is the limiting nutrient for $\underline{S}$. capricornutum in modified EPA mediun. Second, growth decreases with increasing total copper. Third, the variance in growth rate between replicates is larger at or near algistatic copper concentrations. Fourth, exponential growth usualiy ends by the third ciay with the highesi growth rates between days 1 and 2. Although not shown in Fig. 3, some cultures display one day lag periods. It appears that the cells are easily shocked; but in no case was there longer lag periods at higher copper concentrations. 


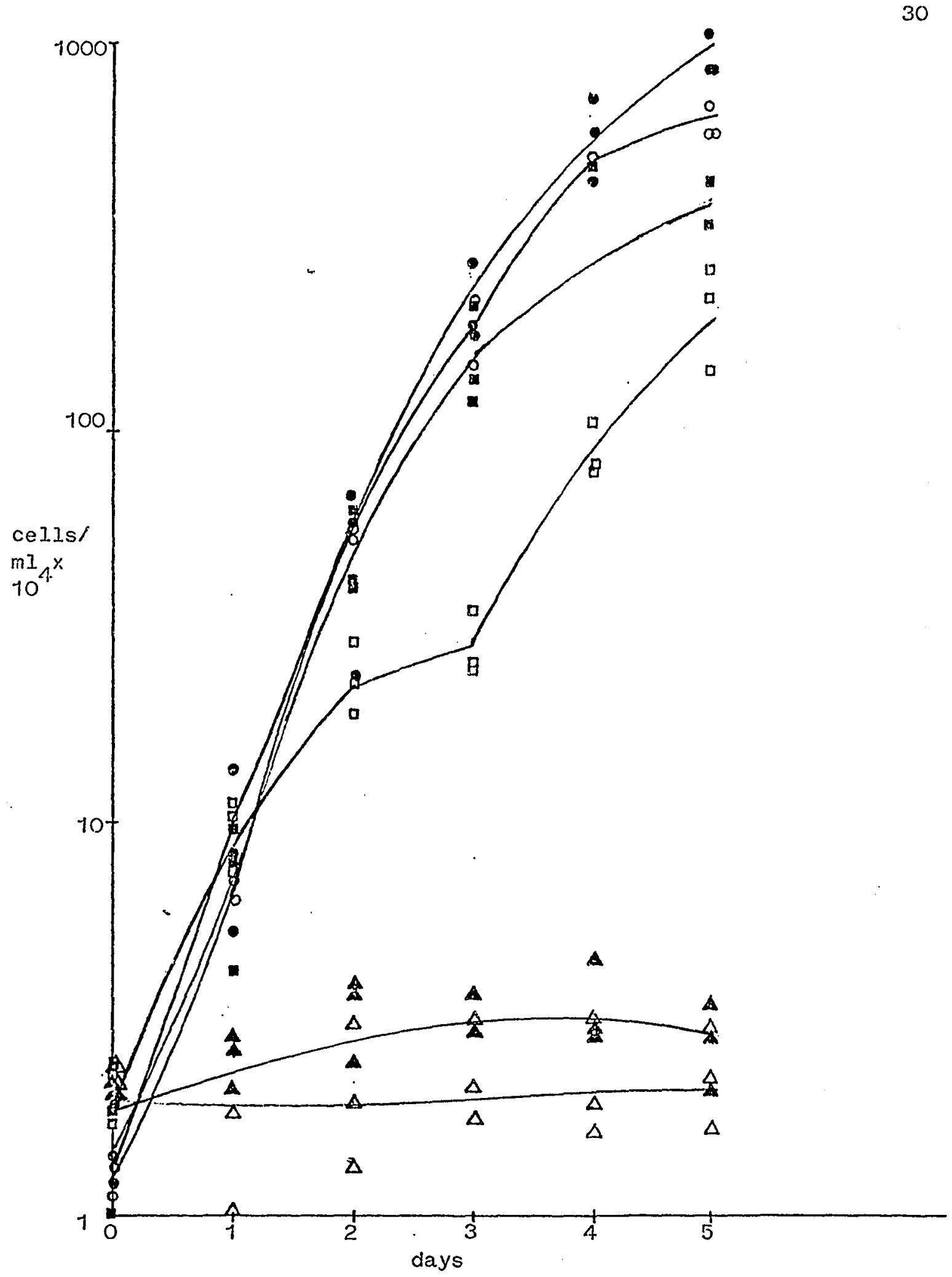

Fig. 3. Copper bioassay growth curve for s. capricornutum cultured in E.P.A. mediurn with $5 \times 10^{-6}$ EDTA: hemacytometer count. Symbols represent the following: $\theta=0 \mathrm{M}$ total copper, $,=3 \times 10^{-6} \mathrm{M}, \mathrm{E}_{\overline{5}} 4.2 \times 10^{-6} \mathrm{M}, \mathrm{D}=4.7 \times 10^{-6} \mathrm{MA} \mathrm{A}=$ $6 \times 10^{-5} M \Delta=2 \times 10^{-5} \mathrm{M}$. 
AFFECT OF COPPER CONCENTEATION ON GROHTH RATE

From the four copper bioassay experiment undertaken in this present research, the growth rates were plotited versus the negative logarithm of total copper concentration and displayed in Fig. 4. Vertical bars represent replicate cultures. The result from these data indicate that growth rate is not correlated directly to the total copper concentration. A family of four curves can be seen. Each curve represents a given chelator at varying concentration in the medium. Toxicity occurs, in the presence of such strong chelating agents as NTA or EDTA, at the point where most of the chelator is saturated with copper; this point is the region of greatest change in the growth rote per addition of total copper. Some research has shown that the number of possible ligand sites for copper (the copper complexing capacity of the mecium) can be measured from this inflection point (Anderson and Morel, 1078; Davey et al., 1973; Sunda and Guillard, 1976; Sunda and Lewis, 1978; Gillespie and Vaccaro, 1978). Davey et al. (1973) used the copper bioassay method with I. pseudonana to measure the copper complexing capacity of artificial seawater, Charleston pond water and Brayton point vater. Gillespie and Vaccaro (1978) used a naturally occurring bacterial population to do a copper bioassay in defined meciiurn and natural water samples. Growth rate in their experiments was measured by the ${ }^{14} \mathrm{CO}_{2}$ uptake method. The experimental measurement of the copper complexing capacity of artificial media with different concentrations of 


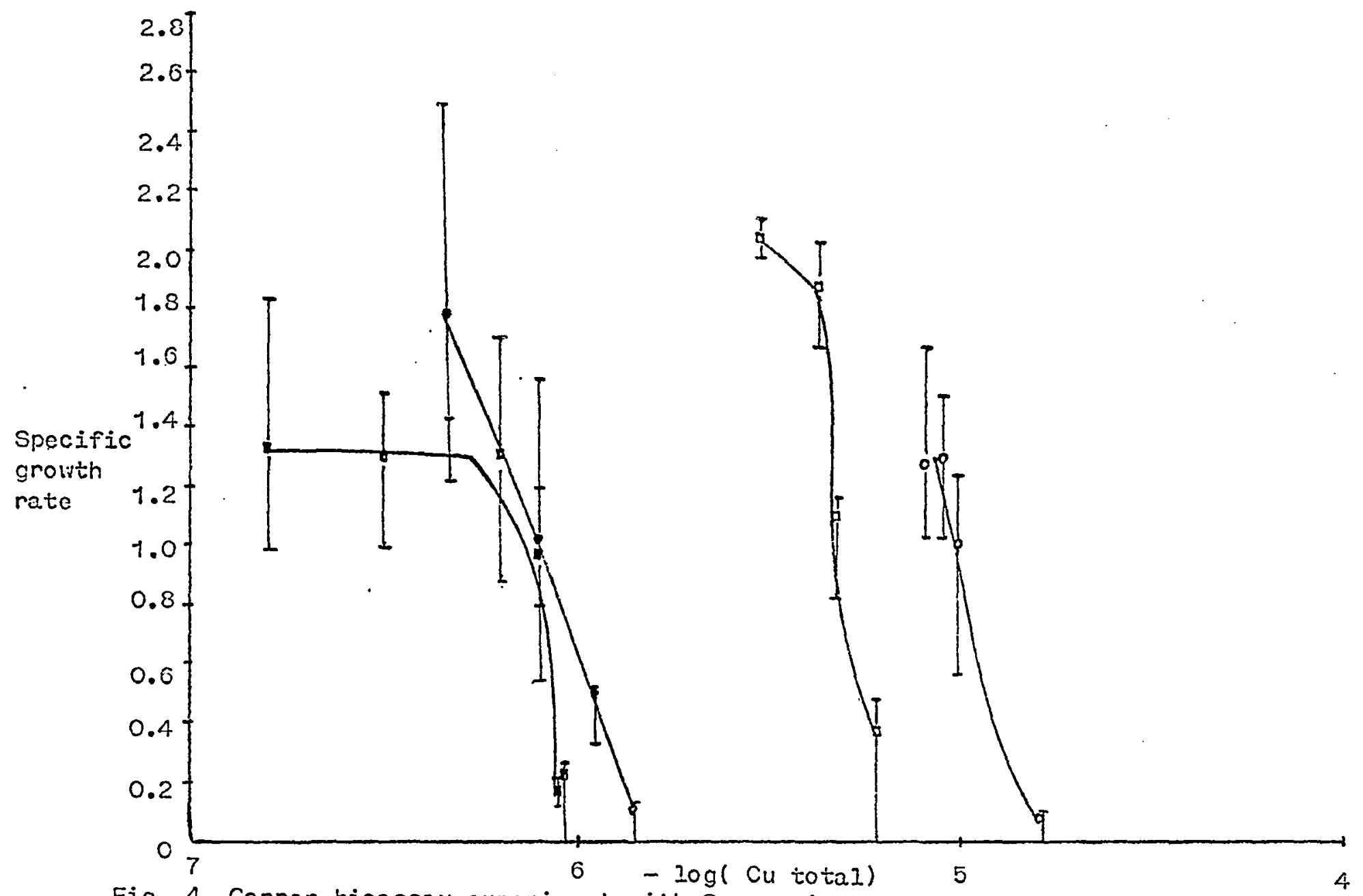

Fig. 4. Copper bioassay experiment vith S. Capricornutum: The specific growth rate versus the negative log of the total copper concentration. Vericical bars represent replicate cultures. Symbols represent the following: $\mathbf{0}=8.00 \times 10^{-7}$. EDTA, $0=1 \times 10^{-6} \| \mathrm{A}$ NTA, $D=5 \times 10^{-6}$ if EDTA, $0=1 \times 10^{-5}$ iA EDTA. 
EDTA, was found to be close to calculated values for copper complexation. Thus, it appears that copper bioassays can provide a reasonabIy good estimate of copper complexing capacities in natural waters. In this present research, the inflection point from each copper bioassay is near the chelator concentration; however, the nethod can only approximate the copper complexing capacity of a medium. A more precise method of calculating copper complexing capacities is discussed later in this section.

Although S. capricornutum is sensitive to total copper (Fig. 4), the actual linear relationship is between growth rate and $\mathrm{pu}^{*}$ in the range 10.25 to $7.25 \mathrm{pcu}^{*}$ units as seen in Fig. 5. This relationship can be expressed in the following manner:

$$
\text { Growth rate }=0.54 \mathrm{pcu}^{*}-3.6
$$

The correlation coeficient for these data is 0.92 for 300 samples. The vertical bars represent the range of growth rates within replicate cultures and the horozontial bars represent changes in pcu ciue to differences in pit within replicate cultures. Between days 1 and 2, the period of time in which the growth rate vas calculated, the pH of the cultures changed by as much a.s $0.4 \mathrm{pH}$ unit. This change in pli is primarily tied in with the carbonate buffering system in the medium. The aqueous $\mathrm{CO}_{2}$ in the system is assumed to be in equilibrium with the air, and thus the total concentration of aqueous $\mathrm{CO}_{2}$ is assumed to be constant at $1 \times 10^{-5} \mathrm{M}$ (see Appendix D for the calculation). Selenastrum capricornutum uses only aqueous $\mathrm{CO}_{2}$ (Goldnan et aI., 1974; King and Novak, 1974). Since 


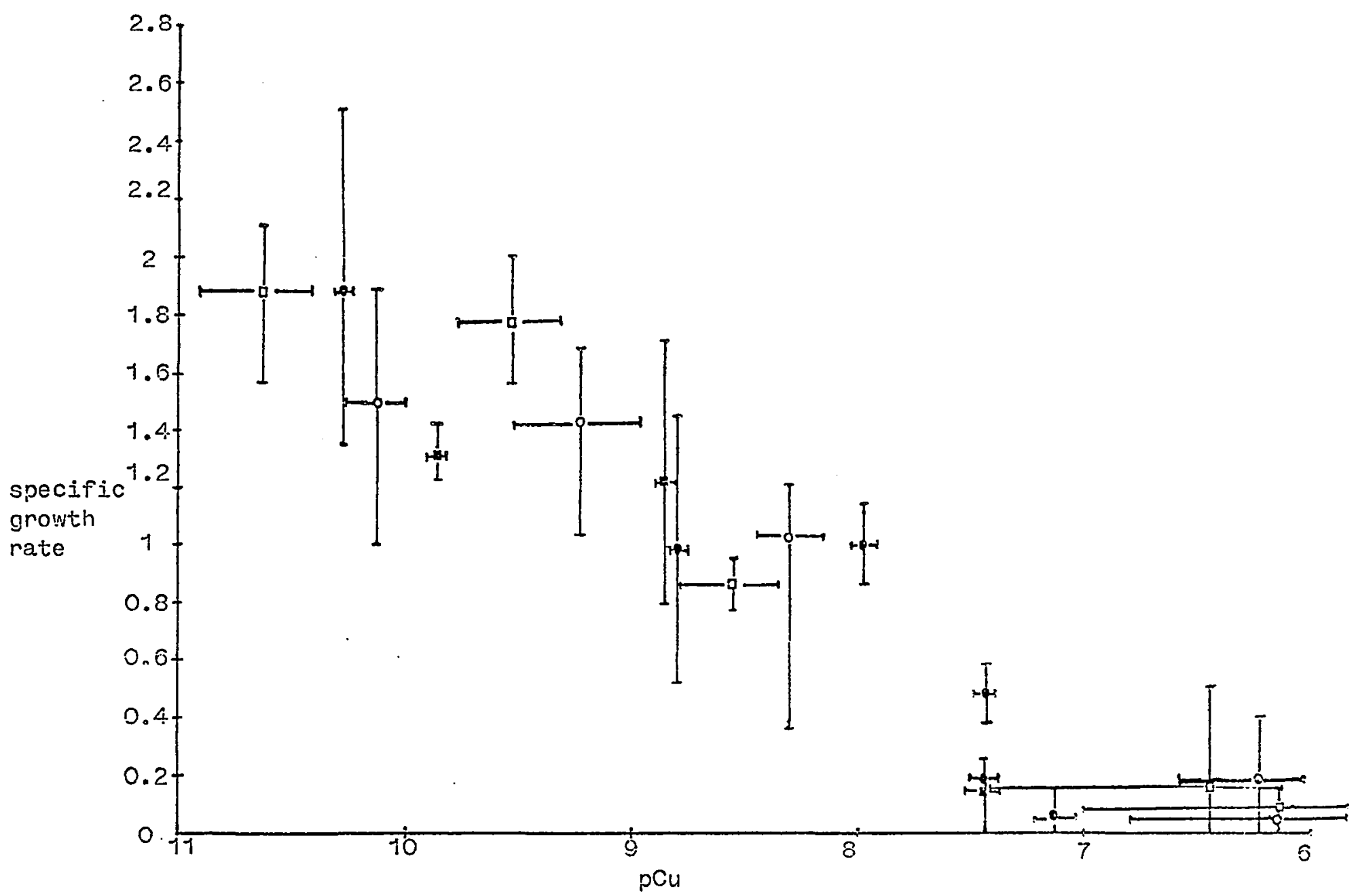

Fig. 5. Copper bioassay experiment with S. capricornutum: specific growtin rate versus pCu. Vertical bars represent replicate cultures, horozontial jars

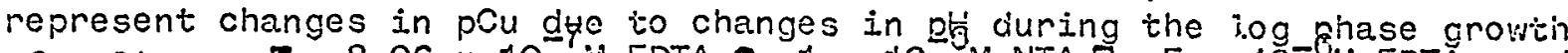
of cultures $=8.06 \times 10^{-1}$ EDTA, $=1 \times 10^{-11}$ NTA, $=5 \times 10^{-6}$ EDTA, and $0=1 \times 10^{-5}$ EDTA. 
the equilibration becween aqueous $\mathrm{CO}_{2}$ and $\mathrm{CO}_{2}$ in the atmosphere is too slow a step to sustain growth, algate musi get $\mathrm{CO}_{2}$ from the soluble bicarbonate and carbonate species. The increase of ptt is due to the release of hydroxide ion when bicarbonate and carbonate species are hydrolyzed to aqueous $\mathrm{CO}_{2}$. Increases in pH also favor the shift from $\mathrm{Cu}^{2+}(\mathrm{aq})$ to $\mathrm{CuOH}^{+}$. The equilibrium constant for the hydrolysis of $\mathrm{Cu}^{2+}(\mathrm{aq})$ is $10^{7.3}$, which is close to the initial $\mathrm{pH}$ of the medium. The $\mathrm{pCu}{ }^{*}$ can be recalculated at the actual pH that has been measured in the culture by use of the MCNEQL procram. For most growth rates, pcu* variability within replicate cultures appears to be no greater than 25 percent of the mean value. Other research also has established this linear relationship between $\mathrm{pCu}$ and growih rate for other organisms as shown in rable 2.

\section{THE REVERSTEILITY OF COPPER TOXICITY}

\section{Selenastrum capricornutum cells from the copper bioassay} study were reculiured on ager containing modified EPA nediuri with $8.06 \times 10^{-7} \mathrm{Mi}$ EDTA. When cells grown for 6 days at various $\mathrm{Cu}^{2+}$ (aq) concentrations were plated onto agar plates with no copper, the results of clividing versus total. count (Table 3.) show that in 48 hours, all cells were viable. No algicidal condj.tions vere found at any $\mathrm{pCu}^{*}$ used in the copper bioassay: thus under the bioassay conciitions, copper was only algistatic. Eartlett et aI. (1973) round that cultures of S. capricornutum grown in modified 
TABLE II

RESEARCH ESTABLISHING A LINEAR RELATIONSHIP BETHEEN pCU AND THE GROUTH RATE

\begin{tabular}{|c|c|c|c|}
\hline Research & Species & Method for & Correlation \\
\hline cited & & deternination & coefficient \\
\hline & & of $p \mathrm{Cu}$ & \\
\hline
\end{tabular}

$\begin{array}{lll}\text { Sunda and } & \text { Monochrysis } & \text { Copper ion } 0.97 \\ \text { Lewis } 1978 & \text { Jucheri } & \text { electrode }\end{array}$

Anderson and Gonyaulax calculated 0.98

Morel 1978 tamarensis

Sunda and Nannochloris calculated 0.98

Guillard 1976 atomos

Sunda and Thalassiosira calculated not linear

Guiliard i976 pseudonana 
COPPER VIALILITY STUDY ${ }^{+}$

\begin{tabular}{|c|c|c|c|c|}
\hline $\begin{array}{l}\text { Total Copper } \\
\text { concentration }\end{array}$ & $\mathrm{pCu}$ & $\begin{array}{l}\text { The Percent } \\
0 \text { hours }\end{array}$ & $\begin{array}{l}\text { cells ur } \\
24 \text { hours }\end{array}$ & $\begin{array}{l}\text { undergoing division } \\
\text { rs } 48 \text { hours }\end{array}$ \\
\hline none added & - & 30 & 01 & 100 \\
\hline none acided & - & 36 & 01 & 100 \\
\hline 1.57 & 10.04 & 20 & 75 & 98 \\
\hline 1.57 & 10.04 & 25 & 77 & 100 \\
\hline 1.57 & 10.94 & 26 & 73 & 100 \\
\hline 3.14 & 10.39 & 23 & 73 & 90 \\
\hline 3.14 & 10.30 & 13 & 78 & 100 \\
\hline 3.14 & 10.39 & 13 & 75 & 100 \\
\hline 4.72 & 9.83 & 49 & 75 & 98 \\
\hline 4.72 & $\$ .83$ & 33 & 00 & 100 \\
\hline 4.72 & 0.83 & 24 & 61 & 100 \\
\hline 6.30 & 0.84 & 27 & 83 & 100 \\
\hline 0.30 & 8.84 & 27 & 63 & 84 \\
\hline 6.30 & $\varepsilon .84^{\circ}$ & 47 & 55 & 100 \\
\hline 7.87 & 7.94 & 21 & 78 & 100 \\
\hline 7.87 & 7.94 & 20 & 72 & 07 \\
\hline 7.87 & 7.04 & 21 & 74 & 97 \\
\hline 7.87 & 7.04 & 10 & 70 & 100 \\
\hline 0.44 & 7.40 & 44 & 03 & 100 \\
\hline 9.44 & 7.40 & 33 & 87 & 94 \\
\hline 0.44 & 7.40 & 24 & 60 & 100 \\
\hline 9.44 & 7.40 & 74 & 78 & 100 \\
\hline 11.0 & 7.25 & 35 & 50 & 100 \\
\hline 11.0 & 7.25 & 12 & 62 & 100 \\
\hline 11.0 & 7.25 & 23 & 67 & 99 \\
\hline 12.5 & 7.25 & 29 & 66 & 97 \\
\hline 12.5 & 7.25 & 28 & 74 & 98 \\
\hline 14.2 & 7.25 & 36 & 71 & 100 \\
\hline 14.2 & 7.25 & 18 & 79 & 97 \\
\hline 15.7 & 7.25 & 15 & 30 & 66 \\
\hline 15.7 & 7.25 & 10 & 77 & 94 \\
\hline 17.3 & 7.25 & 20 & 74 & 100 \\
\hline 17.3 & 7.25 & 25 & 83 & 97 \\
\hline 18.8 & 7.24 & 19 & 65 & 100 \\
\hline 10.8 & 7.24 & 16 & 47 & 100 \\
\hline
\end{tabular}

to- Cells were cyltured on agar with ilodified EPA medium ( $8.06 \times 10^{-1}$ id EDTA without adied copper)

- The cells were initially grown in liquid culture in liodified EPA medium with $8.00 \times 10^{-7}$ it EDTA. The units are $\times 10^{-7} \mathrm{l}$. 
EPA mediun at $8.06 \times 10^{-7}$ H EDTA became algicicial at a to tal copper concentration of $4.72 \times 10^{-6} \mathrm{M}$. This is nore than twice the total copper concentration used in the present copper bioassay experiment for all sets of cultures. In modiried EPA medium containing $3.00 \times 10^{-7}$ Bif EDTA, the pCu, as well as all other soluble copper complexes, is buffered through malachite precipitation when the total copper concentration is $1 \times 10^{-6}$ in or greater. The algistatic action of copper concentrations used in the present copper bioassays was reversible. Although not shown, algal cells wiIl be killed after a considerable build up of malachite. Thus copper precipitation can affect algicidall conditions for $\underline{\mathbf{s}}$. capricornutum. This is also evidenced by the copper bioassay experiments of rorel et a.l. (1978) in which the diatom Skeletonema costatum showed a prolonged lag period when the malachite precipitation increased. Thus, the algicidal nature of metal is cependent not on $\mathrm{Cu}^{2+}(\mathrm{aq})$, but on the precipitation of malachite in the nediun.

A COMPARISON OF $\mathrm{Cu}^{2+}($ a.q) SENGITIVITY OF 30 SPECIES OF ALQAE INCLUDING S. capricornutum

Wialoney and Palmer (1956) grew 30 algal species on Gerloff's medium (Table 4.) in order to compare the growth rate of each species with the total copper concentration. Since growth rates of organisms grown on different media cannot be direct?y compared, as previously shown in Fig. 4., their results were used to calculate 
TABLE IV

GERLOFF'S MEOIU:it

Component

\begin{tabular}{|c|c|}
\hline $\mathrm{Ca}\left(\mathrm{NO}_{3}\right)_{2}^{+t}$ & $4.85 \times 10^{-4}$ \\
\hline $\mathrm{K}_{2} \mathrm{HPO}_{4}$ & $5.54 \times 10^{-5}$ \\
\hline $\mathrm{MgSO}_{4} \cdot 7 \mathrm{H}_{2} \mathrm{O}$ & $1.1 \times 10^{-4 r}$ \\
\hline $\mathrm{Na}_{2} \mathrm{SiO}_{3}$ & $2.05 \times 10^{-4}$ \\
\hline $\mathrm{Fe}_{3}$-citrate & $2.40 \times 10^{-5}$ \\
\hline $\mathrm{H}_{3}$-citrate & $1.43 \times 10^{-5}$ \\
\hline $\mathrm{ZnSO}_{4} \cdot \mathrm{TH}_{2} \mathrm{O}$ & $0.90 \times 10^{-6}$ \\
\hline $\mathrm{inSO}_{4} \cdot 4 \mathrm{H}_{2} \mathrm{O}$ & $1.50 \times 10^{-5}$ \\
\hline $\mathrm{Na}_{2} \mathrm{SiO}_{3}$ & $1.04 \times 10^{-5}$ \\
\hline $\mathrm{AlCl}_{3}$ & $1.50 \times 10^{-5}$ \\
\hline $\mathrm{H}_{3} \mathrm{BO}_{3}$ & $3.23 \times 10^{-5}$ \\
\hline $\operatorname{LiCl}$ & $2.36 \times 10^{-5}$ \\
\hline $\mathrm{CoCI}_{2} \cdot \mathrm{OH}_{2} \mathrm{O}$ & $4.20 \times 10^{-6}$ \\
\hline
\end{tabular}

Final Concentration molar 
pCu* from Gerloff's medium using the MINEQL program. The pCu* values at two growth conditions were compared; one at the incipient condition and the other at the beginning of algistatic conditions for each organism tested (Table 5). The dirferences in $\mathrm{Cu}^{2+}(\mathrm{aq})$ concentration between the most sensitive and least sensitive species shows a range of three orders of magnitude. Several reasons for this variability anong species can be postulated: (1) internal cell physiological differences, (2) development of different active transport mechenisms, (3) cell wall modifications, or (4) extracellular release.

It can also be seen that different strains of the same species show differences in $\mathrm{Cu}^{2+}(\mathrm{aq})$ sensitivity. Two strains of Ankistrodesmus falcatus differ by one-hundred fold in sensitivity to $\mathrm{Cu}^{2+}(\mathrm{aq})$ at algistatic growith conditions. Foster (1977) has also shown differences in $\mathrm{Cu}^{2+}(\mathrm{aq})$ sensitivity between two strains of Chlorella vulgaris; one strain grew much better in stressed copper medium, but both strains were equally sensitive to the same concentrations of intracellular copper. Thus, it can be concluded that physiological behavior of both strains is the same, but the tolerant strain must either lower the $\mathrm{Cu}^{2+}(\mathrm{aq})$ concentration by producing extraceliular products or possess the ability to prohibit transport of copper inside the cells or to transport copper outside the cell. Looking at copper sensitivity in terms of groups or phyla of algae, it is worth noting that diatoms are probably the most sensitive of all algal groups. Differences in copper toxicity between the diatom, Nizschia palea, and a green alga, Chlorella 
A COIIPARISON OF PCU* SENGITIVITY IN 30 SPECIES OF ALGAE

\begin{tabular}{|c|c|c|}
\hline ALEAL SPECIES tested & $\begin{array}{l}\text { pCu* obtaid } \\
\text { INCIPIEIVT } \\
\text { GROLITH }\end{array}$ & $\begin{array}{l}\text { at: } \\
\text { ALGIS } \\
\text { GROUTI }\end{array}$ \\
\hline \multicolumn{3}{|l|}{ Elue-green algae } \\
\hline Calthrix braunii & - & 8.75 \\
\hline Cylindrospermum licheniforme & 17.03 & 10.35 \\
\hline Bicrocystis aeruginosa & - & 11.03 \\
\hline Wostoc muscorum & 10.35 & 9.92 \\
\hline Fhormidium tenue & 11.03 & 10.70 \\
\hline Plectonema mostocorum & - & 11.03 \\
\hline Symploca erecta & 9.92 & 8.15 \\
\hline Ankistrodesmus falcatus & 10.70 & 9.92 \\
\hline Ankiscrodesmus falcatus & 10.35 & 8.75 \\
\hline ChIamydomonas cormunis & 10.35 & 9.92 \\
\hline ChIamydomonas paradoxa & 10.70 & 10.35 \\
\hline Chlorella variegata & - & 10.70 \\
\hline Chlorococcuri botryoicies & - & 9.92 \\
\hline ChIorococcum humicola & $1+.03$ & 10.70 \\
\hline Cocconyxa simplex & 11.34 & 10.70 \\
\hline Coelastrum proboscicieum & 10.35 & 9.92 \\
\hline Gloecystis grevillei & 11.03 & 10.70 \\
\hline Mestaenium calcariorum & 10.33 & 9.92 \\
\hline Oocystis marsonii lacustris & 10.35 & 9.92 \\
\hline Oocystis marsonii & 10.35 & 9.92 \\
\hline Scenedesmus basilensis & 10.35 & 9.92 \\
\hline Scenedesmus obliquus & 8.15 & 8.04 \\
\hline Selenastrum capricornutum & 10.4 & 7.95 \\
\hline Sphaerelia Iacustris & - & 10.70 \\
\hline Stigeocjonium nanum & 11.03 & 9.02 \\
\hline Wannochloris atomus & 10.40 & 8.70 \\
\hline $\begin{array}{l}\text { Diatoms } \\
\text { Achnathes Iinearis }\end{array}$ & 10.70 & 10.35 \\
\hline Glomphonems paruuIuii & 17.34 & 11.03 \\
\hline Nitzschia palea strain 1 & - & 11.03 \\
\hline Nitzschia palea strain 2 & - & 10.35 \\
\hline Nitzschia palca strain 3 & 11.03 & 10.70 \\
\hline Thalassiosira pseucionana & 10.40 & 3.70 \\
\hline
\end{tabular}

6- The $\mathrm{pcu}^{*}$ at which the growth rate is distinguishably lower than the growth rate of control cultures.

8- The $\mathrm{pCu}$ at which the growth rate is close to 0 . 
pyrendoidosa, were compared (Steemann-Nielsen and lilum-Andersen, 1970). Copper toxicity was first expressed in terms of lag periods in the green alga at high pCu* ${ }^{*}$ however, inhibition of photosynthesis was the first sign of toxicity in the diatom. They concluded that copper in the green alga first adheres to the cell wall interfering with cell division while in the diatom, copper penetrates the cell more easily and blocks the photosynthetic pathway. In addition the membranes of the diatom were leaky with the loss of organic matier.

Selenastrum capricornutum is a fairly copper resistant algal species compared to 30 other. species tested. Scenedesmus obliquus and Ankistrodesmus falcatus; green algae and Calothrix braunii and Syploca etecta; blue-green algae are other examples of $\mathrm{Cu}^{2+}(\mathrm{aq})$ resistant algae.

\section{PRODUCTION OF EXTPACELLULAR CAREON}

Total carbon fixed and carbon excreted, in the absence of added copper, were experimentally measured in several ${ }^{14} \mathrm{CO}_{2}$ uptake experiments. The algae were grown in modified EPA medium as described in Materials and Methods. Samples were taken over a 48 hour growth period. The results of ${ }^{14} \mathrm{CO}_{2}$ uptake are shown in Fig. 6. Dark bottIe counts (the ${ }^{14} \mathrm{CO}_{2}$ uptake under dark conditions) have been subtracted from the results. Bottles incubated in the ciark showed very little ${ }^{14} \mathrm{CO}_{2}$ uptake and the amount of ${ }^{14} \mathrm{CO}_{2}$ uptake did not 


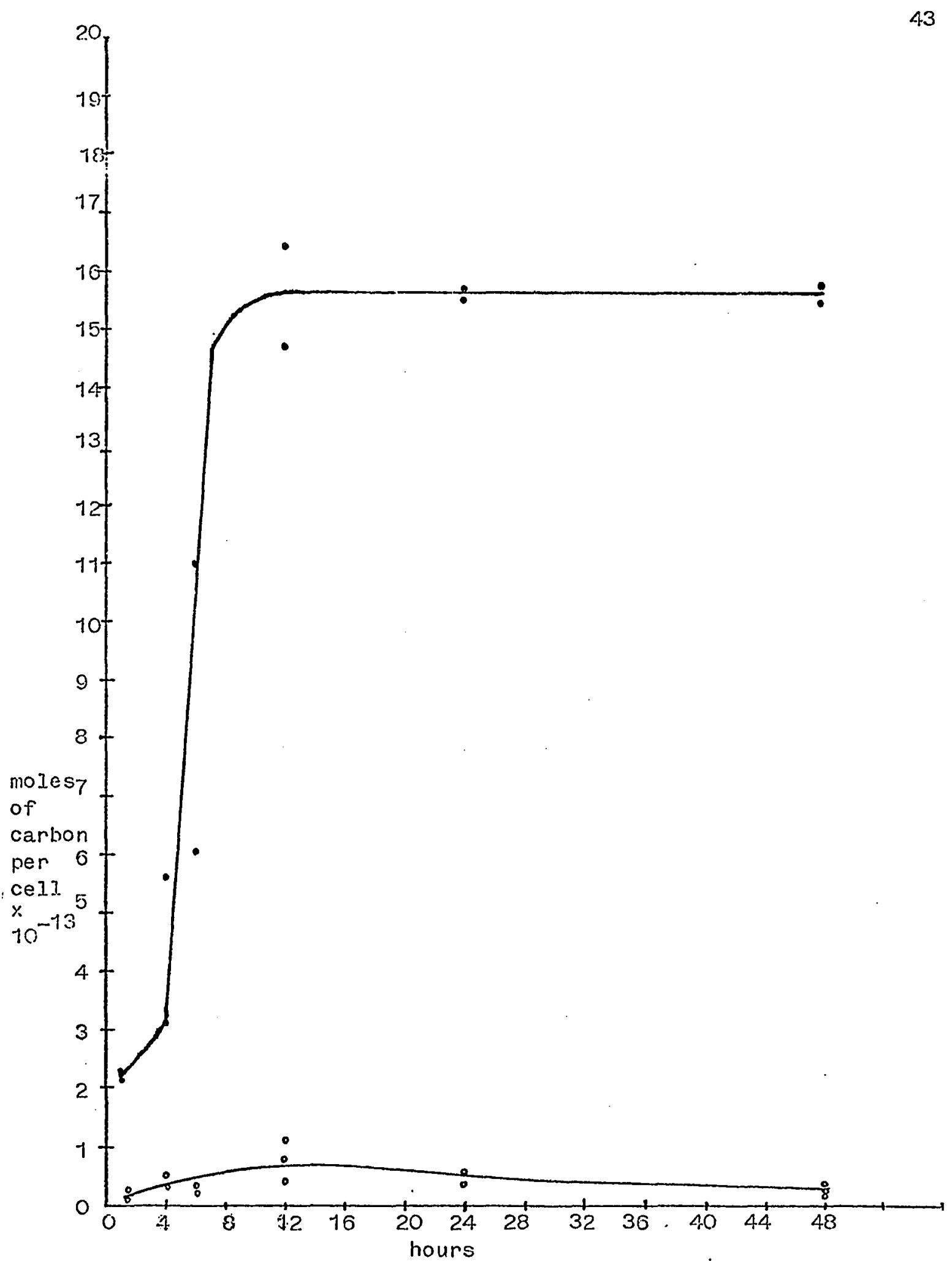

Fi3. 6. Carbon 14 uptake by S. capricornutum. Symbols represent the following: $-=$ the total carbon uptake by the cell and $0=$ the extracellular carbon excreted. 
increase with time. For an inital algal population of $5 \times 10^{4}$ cells per ml, $1.2 \times 10^{-14}\left( \pm 4 \times 10^{-15}\right)$ moles of carbon per cell vas fixed under dark conditions. The uptake in the clark vas one percent or less of the uptake in the light. As seen in Fig. 0. , there is a pronounced increase in the total carbon fixed by the cells during the first 12 hours. This rapid increase of ${ }^{14} \mathrm{CO}_{2}$ is due to the difference in specific activity of carbon (the ratio of ${ }^{14} \mathrm{CO}_{2}$ to ${ }^{12} \mathrm{CO}_{2}$ ) insicie the cell compared with that of the mecium. Noting that celI division occurs once every 9.25 hours, nonsynchronously, a cell uptake rate for carbon can be calculated after this 12 hour equilibration period. The total organic carbon uptake was found to be $1.6 \times 10^{-12}\left( \pm 2 \times 10^{-13}\right)$ moles per cell. The value for ${ }^{14} \mathrm{CO}_{2}$ uptake found in this study is similar to the value of $1.25 \times 10^{-12}$ moles per cell calculoted from the percentage of carbon (GoIdman et al., 1974) and the ciry weight of $\$$. capricornutum (Toerien and Huang, 1973).

The amount of carbon excreted was found to be $5 \times 10^{-14}<+3$ $\times 10^{-14}$ ) moles of carbon per cell. Since the values were obtained using cells cultured in modified EPA mediun ai $3.00 \times 10^{-7}$ h EDTA

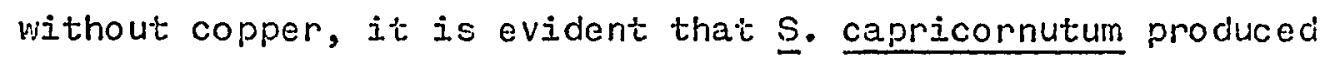
extracellular products in the absence of toxic concentrations of copper. The amount of carbon excreted is about 3 percent of the total amount fixed by the cell.

As seen in Tablo 6., much higher anounts of excreted carbon 
TAELE VI

EXTrACELLULAR RELEASE IN ALCAE AS A PERCENT OF TOTAL ASSIMILATED CARBON

\begin{tabular}{|c|c|c|}
\hline Author & Species & $\begin{array}{l}\text { Percent } \\
\text { excreted }\end{array}$ \\
\hline Lewin 1956 & Chlamydomo nas spp. & $15 \%-57 \%$ \\
\hline Jones 1962 & Porphydridium cruentum & $15 \%$ \\
\hline Prager et a1. 1959 & Katodinium dorsalisulcum & $90 \%$ \\
\hline $\begin{array}{l}\text { Moore and Tischer } \\
1955\end{array}$ & Anabaena flos-aquae & $28 \%$ \\
\hline $\begin{array}{l}\text { Guillard and Hellebust } \\
1971\end{array}$ & Phaeocystis pouchetti & $26 \%-36.8 \%$ \\
\hline Fogg 1965 & $\begin{array}{l}\text { naturaliy occurring } \\
\text { phytoplankton }\end{array}$ & $7 \%-50 \%$ \\
\hline Watt and Fogg 1966 & $\begin{array}{l}\text { naturally occurring } \\
\text { phytoplankton }\end{array}$ & $13 \%-92 \%$ \\
\hline
\end{tabular}


have been reported. Smalier values of excretion, between 0 to 4 percent, have been reported by liajok et al. (1906) and Craigie et al. (1900) for a red and also a green alga. lieiny of the papers which report high values for extracelilular excretion used the ${ }^{14} \mathrm{CO}_{2}$ uptake method. The reason for the high values of extra.celiular excretion reported by many papers may be found in a paper entitled, "Excretion of Organic Waiter by liarine Phytoplankton: Do healthy cells do it?" (Sharp, 1977). Sharp (1977) states that the anount of excretion by phytoplankton may be an arififact, i.e. filtration or centrifugation may calise cell damage which would give an anomaly. This anomaly would make it appear that extracellular prociucts had been released by the cells ciuring growth. Sharp also states the need for controls which would eliminate problems wjth residual inorganic carbon and cell density effects on excretion. Fogg (1973) lists six possible sources of error from measured excretion by ${ }^{14} \mathrm{CO}_{2}$ uptake mathods. The error found most frequently is damage to the cells by (1) filtration, (2) centrifugation, and (3) changes in the ionic strength of the medium. Errors less commonIy found are: (1) inadequate removal of inorganic ${ }^{14} \mathrm{CO}_{2}$ from the samples, (2) organic contamination from bicarbonate carbon-14 ampules, (3) loss during the storage and transport of field samples, (4) incubation times, and (5) errors introduced by the use of small volumes of. filtrate in carbon-14 analysis. All of these errors would lead to high excreition values which are artiracts. Sharp (197e) states that algae probably 
actively excrete naterials, but at low levels. The present research attenptcd to minimize these errors which have been shown to create artificial excretion products.

III. THE CONCENTPATION OF EXTRACELLULAR PRODUCTS EY USE OF ANBERLITE XAD-8 RESIN

The algal filtrates require a concentration step in the analysis of copper complexation. This step eliminates cations and inorganic molecules, removes chelating agent i.e. EDTA or NTA, and concentrates extracellular products. Concentrations of exiraceliular products greater than $1 \times 10^{-6}$ li are needed for detection of copper complexation using a copper ion electrocie. Swallow et al. (1978) using the same methods as employed in this research for determination of copper complexation found little copper complexing capacity in unconcentraced algal filtrates. This may be due to the low concentration of extracellular products present in the medium.

In the concentration of organic molecules, there are only a few techniques which are efficient and convenient. Rohm and Haas Company (Anonymous, 1970) has produced several non-ionic exchange resins which are userul; included are XAD-2 (a polystyrene resin), XAD-7 and XAD-C resins (acrylic ester polymer). In the present

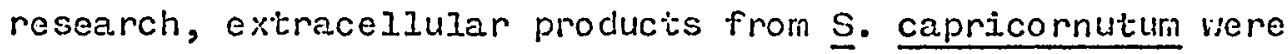
concentrated on XAD-8 resin. 
Charged complexes and sma.I ions of substantial net charge wiII not concentrate on XAD resin. Thus, by adjusting the pH of the material to be concentrated, inorganic ions and chelating agents can be eliminated during this concentration step.

hantoura and Riley (1975b) concentrated ciecayed products from two species of algae, Hemiselmis referscens and Dunaliella primolecta, on XAD-2 resin. The filtrates were acidiried to pH 2.2 prior to the concentration step. Acisorption efficiencies of 92 percent and 86 percent respectively, were obtained for these two species. The percent recovery from the elution of the products With methanoI and $2 M$ ammonium hydroxide $(1: 1, v / v)$ was measured at 85 percent and 82 percent respectively. This result suggests that adsorption efficiencies for algal products are high on XAD resin and that a majority of these algal products are moderately basic. Table 7. shows the resin efficiencies for the exiracellular products from $S$. capricornutum. Samples were acidified to pH 1.7 prior to the concentration step. This $\mathrm{pH}$ was chosen because high recovery was obtained and because natural humic substances have been reported to show maximum retention by the column near this pH (liantoura and Riley, 1975b). Labeled carbon-14 extraceIlular products from 3 . capricornutum were concentrated on an XAD-8 column. The percentage of extracellular products retained by the resin was calculated to be 95 percent and 96.5 percent for two separate and identical experiments. In addition, the recovery' of materials from the resin by methanol elution vas calculated 
TABLE VII

THE EFFICIENCY OF XAD-8 RESIN

A. THE EFFICIENCY BASED ON THE ACTIVITY DIFFERENCES BETLEEN LABELED ${ }^{14} \mathrm{CO}_{2}$ EXTRACELLULAR PRODUCTS BEFORE AND AFTER FILTRATION THROUGH XAD-8 RESIN.

$\begin{array}{cllc}\text { Experiment } & \text { Activity }^{+} & \text {Activity } & \text { Percent Efficiency } \\ 1 & 915.2 \pm 41.73 & 44.62 \pm 15.25 & 95.13 \\ 2 & 12,705 & 435 \pm 185.8 & 96.57\end{array}$

B. EFFICIENCY BASED ON THE TOTAL ACTIVITY OF METHANOL ELUTION AND THE TOTAL ACTIVITY OF THE ELUATE

$\begin{array}{cllc}\text { Experiment } & \begin{array}{l}\text { Total } \\ \text { Activity }\end{array} & \begin{array}{l}\text { Total } \\ \text { Activity }\end{array} & \text { Percent Efficiency } \\ 3 & 5.15 \times 10^{5} & 5.04 \times 10^{5} & 97.9\end{array}$

+- The activity before filtration in countes per 10 minutes per $5 \mathrm{ml}$ filtrates is calculated in experiments 1 and 2 .

\#-- The activity after filtration in counts per 10 minutes per $5 \mathrm{ml}$ filtrates is calculated in experiments 1 and 2 .

*- Total activity was calculated from the radioactivity concentrated by XAD-8 resin in experiment shown above.

(2-- Total activity was calculated from counts per 10 minutes per $5 \mathrm{mI}$ sample corrected to base of the total volume of methanoleluate. 
to be 97 percent (Table 6., experiment 3.). From the high efficiency obtained, it appears that $X A D-8$ resin is effective in concentrating the extracellular products at pli 1.7 .

The holding capacity of the XAD-8 resin was deternined. This capacity is clefined in terms of milliliters of filtrate that can be filtered through a gram of resin before exhaustion of the resin, as outlined in Method and Materials (subsection VI.). Algel filirate, initially containing a final yield of $6 \times 10^{6}$ cells per ml Grown in modified EPA medium with $8.06-\times 10^{-7}$ M EDTA without copper) was concentrated on a column containing 11 grams of resin. Fig. 7. shows a plot of carbon-14 activity versus liters of algal filtrate passed through the column. This figure can be restated as a. holding capacity of 4.5 Iiters per gm of resin at pit 1.7 . For this research no more than 20 percent of the holding capacity was used.

IV. THIN LAYER CHROMATOGRAPHIC (TLC) SEPARATION OF CONCENTRATED PRODUCTS

Filtrates from 16-liter cultures of $\underline{S}$. capricornutum Were concentrated on XAD-8 resin. The concentrated extracellular products were eluted with methanol and the products were separated Dy TLC as described in libterials and fiethods (subsection VII.). Tive types of filtrates were used. One of the filtrates was obtained iron cells grown in a medium containing a copper concentration Iarge snough to reduce the growth rate by one-half, while the second 


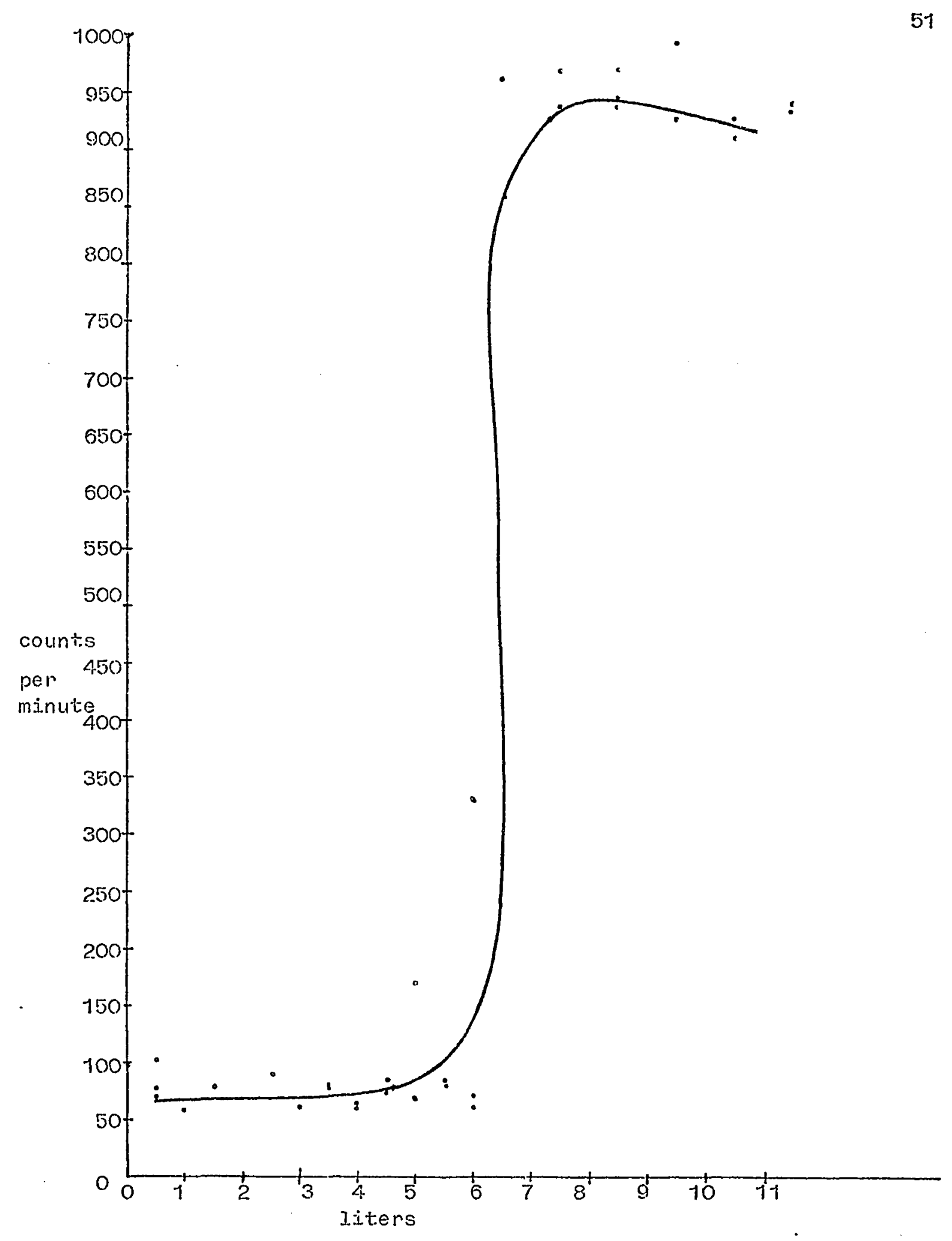

Fig. 7. The holding capacity of XAD-8 resin for carbon 14 labeled extracellular products from S. capricornutum at a $\mathrm{pH}$ of 1.7 . 
filtrate was obtained from cells groun in a medium containing no acided copper. The concentrated extraceliular products from the mediun containing no adied copper were separated on a twocizmensional TLC plete (Fig. 8.). Visualization of the prociuts by ninhydrin, iodine staining or ruorescence showad at least 17 products. The concentrated extraceliular prociucts from the mediun containing near toxic levels of copper were separated in a similar manner and the results are shown in Fig. 9. Visualization of the prociucts sinowed at Ieast 13 products. There is a great deal of variability in the migration of the producis. However, in the concentrate from the medium containing copper, one aciditiona.I product (which cen be detected by j.ts yellob color and by iodine staining) was alvays found to separate during chromatorgaphy. This product is shown by the arrow in Fig. 0 . As shown later, the copper compiexing capacity of this prociuct is small and could be due to the absorpition of copper to a ligand which may not be totally removed during the acidification and concentration steps. Preparative TLC plates vere run in duplicate. One plate (to which reduced amounts of extraceliular prociucts were applied) was developed and the prociucts bere detected by the various methods: i.e. color, iodine staining, fluorescence or rinhydrin staining. Separate irections were isolated from the other preparative plate by the rrocecure described in haterials and Methods (subsection VII.). f. Ecmparison between products obtained from the copper-free and 

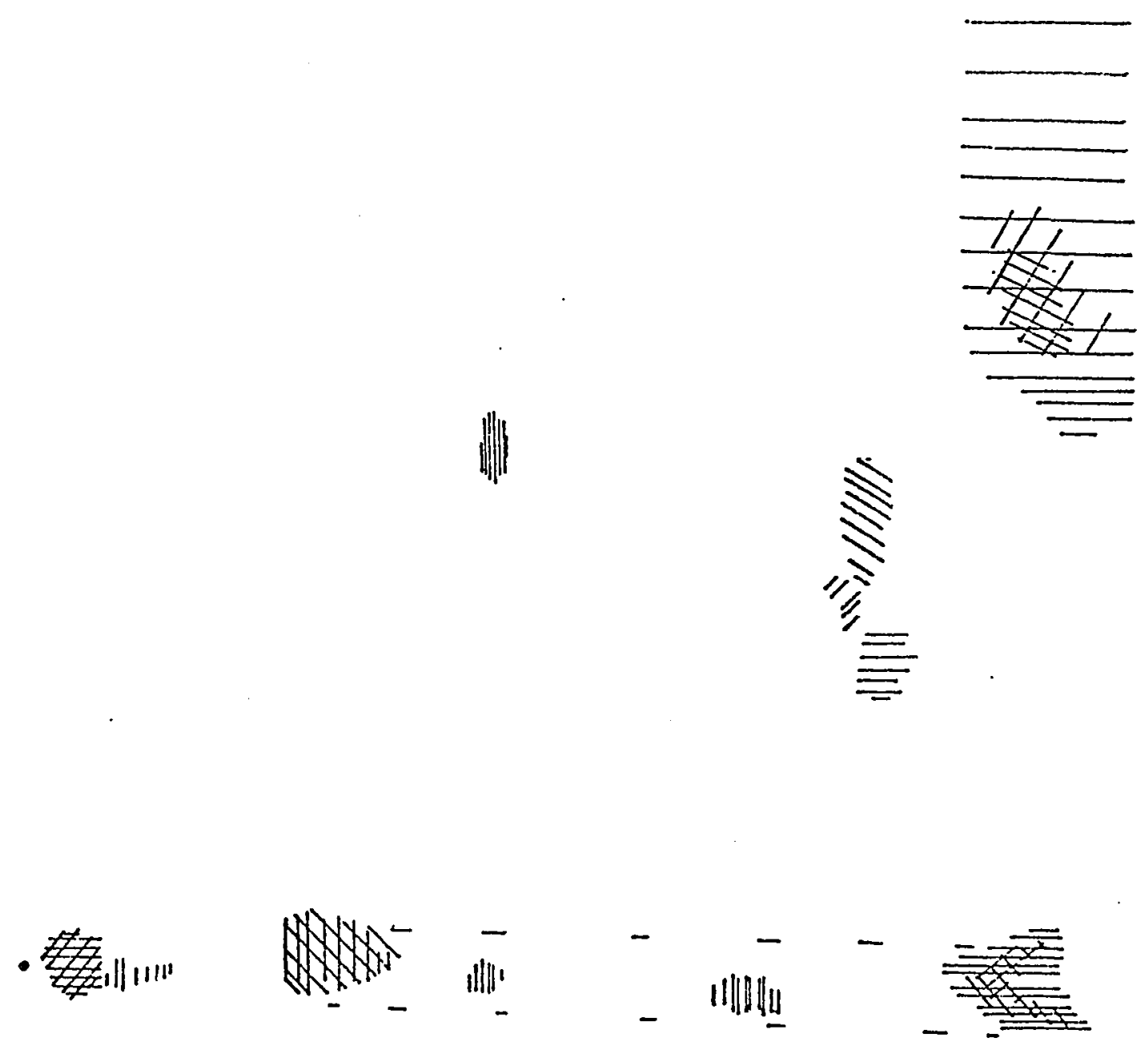

Fig. 2. Two-dimensional (TLC) chromatogran of concentrated Algal produrits from 5 . capricornutum, srot: w/o $\mathrm{Cu}$. The first separation is in the verticol. direction with ethyl acetate, second separation, horozontial direction from left to right with $\mathrm{n}$-butanol, formic acid and water 4:1:1 v/v/v. Symbols represent the following: $I I I=$ ninhydrin positive reaction, $\equiv=$ rluorescent activity, $/ /=$ visible, $/ l l=$ iodine staining. 


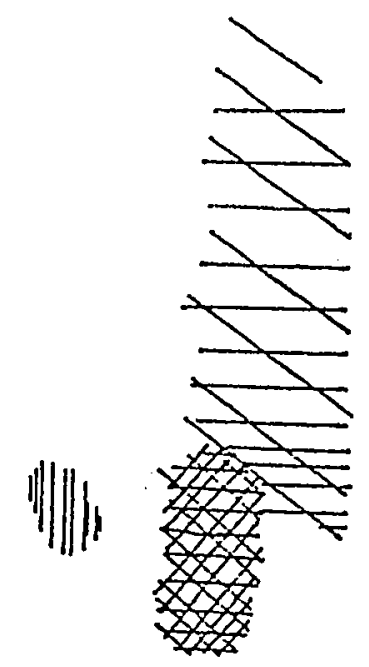

-

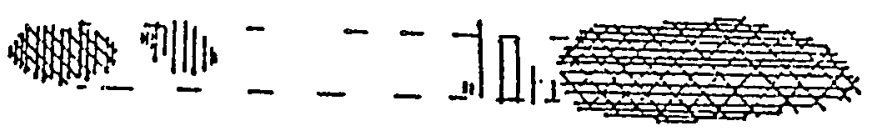

Fig. 9. Tiso-dimensional (TLC) chromatogram of concentrated algal procucis from $S$. capricornutum, grown with copcer. The first separation is in the vertical direction with ethyl acetate as the solvent. The second separation is in the horozontial direction from left to right with $n$-butanol, formic acid and water 4:1:1 v/v/v. Symbols represent the following: $\| I=$ ninhydrin posjtive reaction, $\equiv=$ fluorescent activity, $M=$ visible, $M=$ iodine staining. 
copper containing media is shoun in Table 3 . Essentially, both TLC plates represents the same mixture of products.

V. COPPER COIAPLEXING CAPACITIES OF ALCAL FILTRATES AND CONTROL SOLUTIONS

\section{DEFINITION}

"Copper complexing capacity" of a solution is cierined as the number of copper binding sites in moles per liter. The capacity is the number of copper binciing sites, but not a measure of the types of copper-ligand complexes prosent.

\section{METHOD AIND THEORY}

The copper complexing capacity las measured with a copper selective electrode, as outlined in Nethods and liaterials (subsection VIII.). Copper complexing capacities have been measurec for various natural water samples using this potentionetric method (Ramamoorthy and Kushner,t975; Suncia and Hanson, 1973; Gwallow ei al., 1978; Sunda and Lowis, 1978).

Copper complexing capacities were based on the following theory. Under excess copper conditions the concentration of bound metal is equal to the total ligand concentration. Thus, the following relationship is established for mononuclear complexes:

$$
\Sigma_{i}\left(C_{i}\right)=L_{t}
$$

where $L_{t}$ is the total Iigand concentration and $\Sigma_{i}\left(C_{u} L_{i}\right)$ is the sum of all metol-Iigand complexes, and i is the type of ligand. Assuming onjy one metal-1igand stoichiometry, the mass jatance of 
DETECTION OF SEPARATED FRACTIOISS OF EXTRACELLULAR PRODUCTS

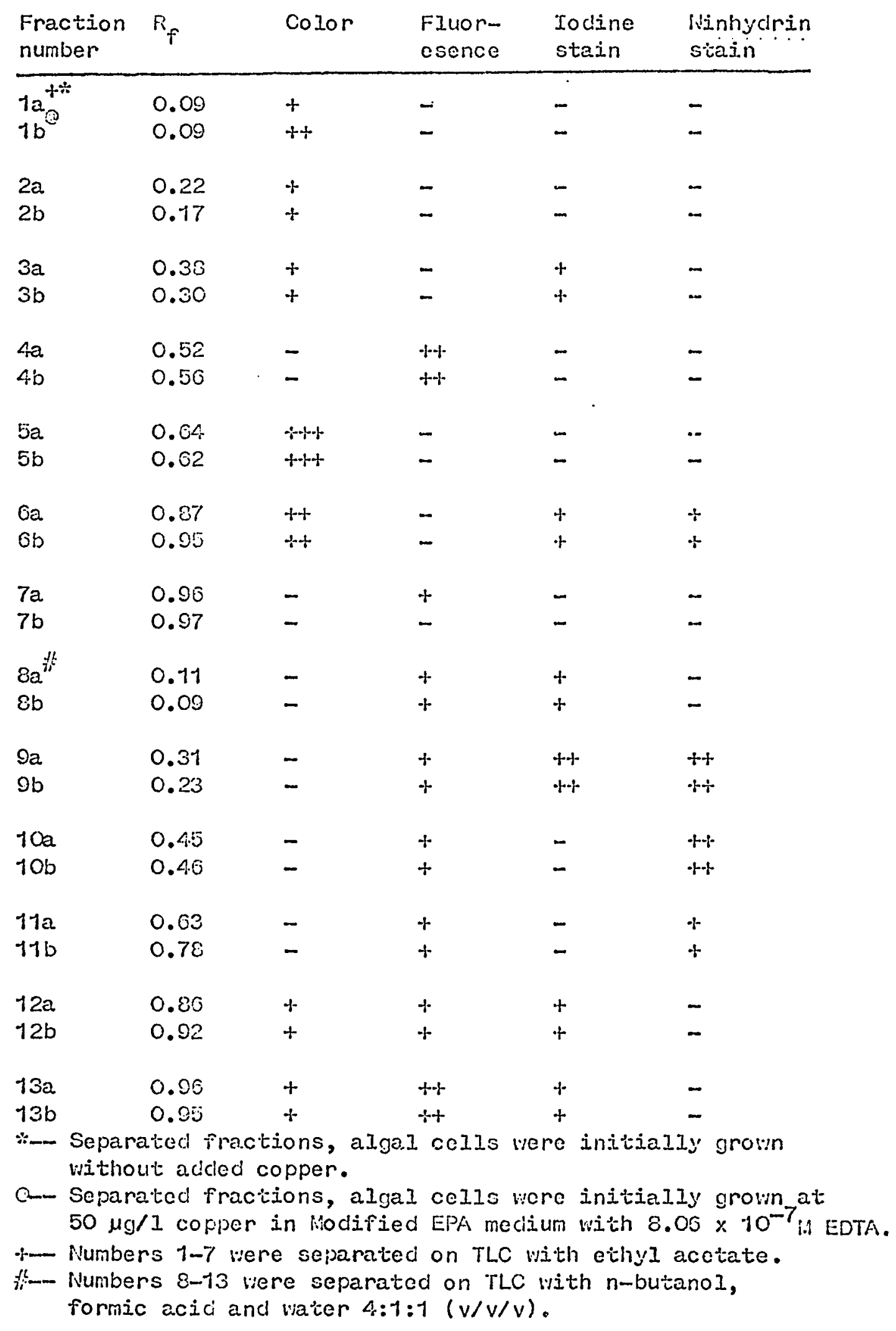


metal in the systen can be expresseci as:

$$
\mathrm{Cu} u_{t}=\mathrm{Cu} u^{2+} \mathrm{z}+\Sigma_{i}\left(\mathrm{CuL} \mathrm{L}_{i}\right)
$$

where $\mathrm{Cu}_{t}$ is the total metal in the system and $\mathrm{Cu}^{2+} \mathrm{z}$ is the sum of a.11. copper-carbonate and copper-hydroxide and ionic copper concentrations. The $z$ term is defined in Appendix D. Substituting equation (5) into equation (0), the following equation can be cierived for the determination of the copper complexing capacity of a solution:

$$
C_{u_{t}}=\mathrm{Cu}^{2+t} z+\mathrm{L}_{t}
$$

At any stated pH, under excess copper conditions, all ligand sites are bound to copper, thus any change in the total copper concentration yields an equal and proportional. increase in free copper, copper-hydroxide, and coppermcarbonate species. As shoun in Apperidix D, if the ionic copper is measured at an acidic pH, less than 5.0 , the amount of copper-hyciroxide and copper-carbonate species approaches zero and can be neglected, hence z equals unity. A plot of $\mathrm{Cu}_{t}$ versus $\mathrm{Cu}^{2+}(\mathrm{aq})$ gives a slope of $t$ with an $x$-intercept equat to $L_{t}$, the copper complexing capacity of the solution. Fig. 10. shows a representa.tive plot for a solution of NTA $\{1.13$ $\left.\times 10^{-4} \mathrm{~m}\right)$. A sinilar plot for an algal filtrate is shown in Fig. 11. Both experiments were performed at pH 4.0 . 


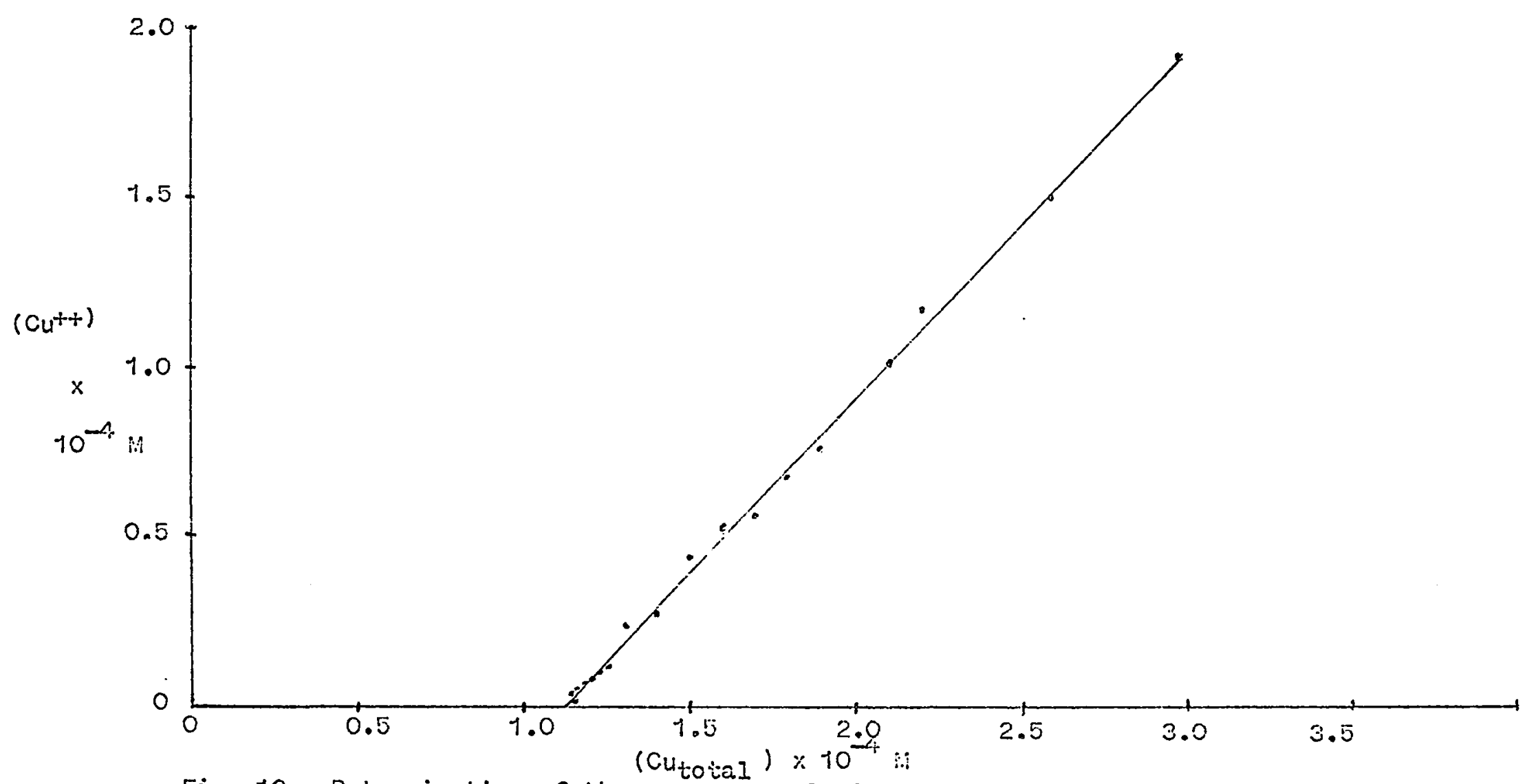

Fig. 10. Deteraination of the copper complexing capacity from a copper

titration of $1.13 \times 10^{-4}$ in NTA solution, pit=4.0 in $1 \times 10^{-1} \mathrm{lia}$

$\mathrm{NHO}_{3}$. 


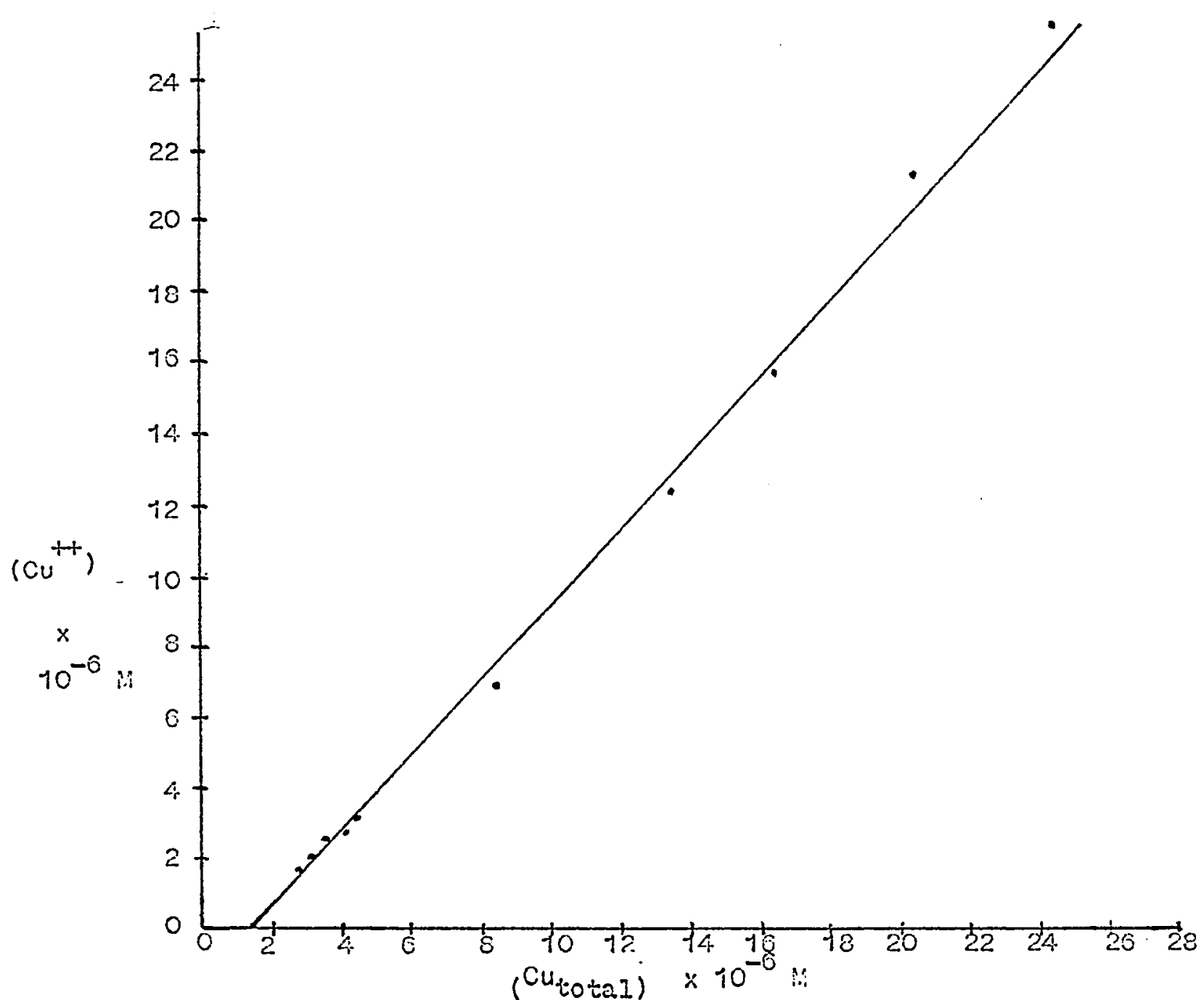

Fig. 1\%. Determination of the copper complexing capacity from a copper titration of a solution containing extracellular prociucts from 3. capricornutum, pris=4.0 in $1 \times 10^{-1}$ in $\mathrm{kl}_{3}$. 
THE COPPER COMPLEXING CAPACITY OF EXTRACELLULAR PFODUCTS FROM UNCONCENTHATED ALGAL FILTFATES

The copper complexing capacity of 7 day algal filtrates initially containing $3 \times 10^{-6} \mathrm{M}$ EDTA was measured. Complexotion due to inorganic nutrients and EDTA were subtracted from the total copper complexing capacity in order to determine the capacity of the extracellular products alone. This extraceliular copper complexing capacity was experimentally cietermined at $1.8 \times 10^{-7}$ lit $5.7 \times$ $10^{-8} \mathrm{M}$ ), at $\mathrm{pH} 5.0$. These results indicate that the release of extracellular products might have a marginal effect on the ionic copper concentrotion in weakly chelated laboratory medium, but in natural waters where concentrations of complexing agents are Iow, the effect of these extraceliular products may be quite significant in regulating $\mathrm{Cu}^{2+}(\mathrm{aq})$.

The copper complexing capacity of several controll solutions was considered. Experimental copper complexing capacities using copper selective electrodes were compared with theoretical values for different control solutions (Table 9.). The results show good correlation between measured and calculated values (copper complexing capacities).

In order to check if XAD-8 resin had any affinity for EDTA in solution at pH 1.7, another control. was devised. The copper complexing capacities of solutions containing EDTA were detemined 
TAELE IX

THE COPPER COMPLEXING CAPACITY OF MODIFIED EPA MEDIUH CONTAINING VARTOUS EDTA CONCENTRATIONS

\begin{tabular}{|c|c|c|}
\hline & \multicolumn{2}{|c|}{ COMPLEXING CAPACITY } \\
\hline EDTA CONCENTTRATION & CALCULATED VALUE & I.EASASURED VALUE*** \\
\hline 0 & $1.05 \times 10^{-7}$ & $2.04 \times 10^{-7}$ \\
\hline $5 \times 10^{-6}$ & $5.17 \times 10^{-6}$ & $5.10 \times 10^{-6}$ \\
\hline $3 \times 10^{-6}$ & $3.17 \times 10^{-6}$ & $3.08 \times 10^{-6}$ \\
\hline
\end{tabular}

Q- Calculated using the HINEQL program in molar concentration.

*-measured using the copper ion selective electrode method in molar concentration. 
before and after passing a solution through WAD-E resin. In duplicate experiments the copper complexing capactey before fjltering was $6.55 \times 10^{-0}$ in and $7.04 \times 10^{-6}$ lit. After passage through the column, complexing capacities of $6.61 \times 10^{-6}$ hand $7.09 \times 10^{-6}$ hi were obtained. It is apporent that there is little difference between the copper conplexing capacity of the effluent and influent for either solution. Thus, it can be said that XAD-B resin does not concentrate EDTA under the experimental concitions used for this work.

A control experiment tas also devised in order to determine the extent of uptake of EDTA by 3 . capricomnutum, since EDTA is the primary copper buffering agent used in modified EPA medium. Seven day algal filtrates, cultured in modified EPA nedium with $3.0 \times 10^{-6}$ if EDTA (without copper), were concentrated on VAD-8 resin. A comparison between the copper complexing capacity of this eluate and that of fresh modified EPA medium with $3.0 \times 10^{-6}$ i.j EDTA was made. The copper complexing capacity of the nutrient medium was calculated to be $3.16 \times 10^{-6}$ whjle direct measurenentis gave a mean value of $3.08 \times 10^{-6} \mathrm{H}$. The a.lgal filtrate from XAD-8 resin had a measured copper complexing capacity of $3.11 \times 10^{-6}$ M. These results indicate that there is little difference between uninoculated modified EPA medium and the o.Igal filtrate arter passage through $2 A D-3$ resin. Since EDTA j.s not concentrated by the resin, most of the inorganics and all of the EDTA must: be 
in the cffluent. These results suggest that $S$. cepricornutum did not concentrate EDTA inside the cell. Since the ceIIs vere filtered from the medium at physiological pil, these results also indicate that EDTA was not concentrated on the cell surface.

THE COPPER COMPLEXING CAPACITY OF CONCENTRATED EXTRACELLULAR PRODUCTS

As shown in Table 10., copper titrations were perforned at pit 5.0 and 6.0 for concentrated filtrates in which cel.ls were either grown without copper or at a copper concentration high enough to reduce the growth rate by one-half. The copper complexing capacity of concentreited products obiained fron filirates of cells grown without coppen is $2.0 \times 10^{-7}$ ( $\left.\pm 7 \times 10^{-8} \mathrm{~m}\right)$. Even though there is a large variabijity in copper complexing capacity, the results are comparable to those calculated from unconcentrated algal fijtrates. The concentrated fraction obtained from filtrates of cejts grown with copper had a copper complexing capacity of $1.8 \times 10^{-7}$ if $\pm 6 \times 10^{-8}(19)$. The copper complexing capacities of both concentrated alga.7. filtrates were calculated back to the capacity of the unconcentrated nutrient medijum. A one-tailed t-test was performed in order to determine if there vas a signiricant difference between the two sets of copper complexing capacities for concentrated filtrates. The resulis indicate, at a 95 percent conficlence level, that there is no cifference between the two 
TABLE $\propto$

THE COPPER COMFLEXIHG CAPACITIES, CONDITIONAL STALILITY CONSTANTS AND AVERAGE I:OLECULAR I:EICHTS OF CONCEMTPATEO EXTRACELLULAR PFODUCTS FROH SE Ienastrum capricornutum

\begin{tabular}{|c|c|c|c|c|c|}
\hline \multicolumn{2}{|c|}{$\begin{array}{l}\text { Copper pH } \\
\text { titration } \\
\text { experiment }\end{array}$} & \multicolumn{2}{|c|}{$\begin{array}{l}\text { Copper Log } K_{c}^{* *} \\
\text { complexing } \\
\text { capacity }\end{array}$} & $\begin{array}{l}\text { Molecular } \\
\text { weight } \\
\left(x \cdot 10^{4}\right)\end{array}$ & $\begin{array}{l}\text { Correlation } \\
\text { coefficient }\end{array}$ \\
\hline $1 A^{+}$ & 5.0 & 1.41 & 5.67 & 11.0 & 0.977 \\
\hline $2 A$ & 5.0 & 1.17 & 5.77 & 13.2 & 0.990 \\
\hline $3 A$ & 0.0 & 3.01 & 5.39 & 5.14 & 0.980 \\
\hline $4 A$ & 0.0 & 2.61 & $5.4+1$ & 5.91 & 0.987 \\
\hline $18^{\frac{12}{t h}}$ & 5.0 & 1.95 & 5.55 & 7.92 & 0.007 \\
\hline 28 & 5.0 & 2.49 & 5.45 & 5.42 & 0.990 \\
\hline $3 E^{\prime}$ & 5.0 & 1.12 & 5.00 & 11.5 & 0.997 \\
\hline 48 & 6.0 & 2.15 & 5.53 & 6.28 & 0.081 \\
\hline $5 E$ & 0.0 & 2.09 & 5.80 & 6.46 & 0.870 \\
\hline \multicolumn{6}{|c|}{$\begin{array}{l}\text { Q- The units are in noles per gran } * 10^{-6} \text {. } \\
*-K \text { is the conditional stability constant. } \\
+-A^{e} \text { represents concentrated filtrates in which cells were } \\
\text { initially grown in the absence of added copper. } \\
: \text { E represents concentrated filtrates in which cells } \\
\text { were initialiy grown in } 50 \mu g / 1 \text { copper in modified EPA } \\
\text { medium at } 8.06 \times 10^{-7} \text { EDTA. }\end{array}$} \\
\hline
\end{tabular}


groups. It appears that $\underline{\Phi}$. capricornutum grown at near toxic copper concentrations does not produce prociucts which specifically complex copper. As discussed later, average conditional stability constants and average molecular weights for these two types of concentrated XAD-B materials furthur support this conclusion.

THE COPPER COMPLEXING CAPACITY OF SEPARATED PRODUCTS

The copper complexing capacity of 13 concentrated and TLC separated fractions are listed in Table 11. It can be seen that the slope for most plots of total copper concentration versus $\mathrm{Cu}^{2+t}(\mathrm{aq})$ concentration is approximately + with greater than 90 percent correlation. Although not shown, only one-third of the total copper complexing capacity bas recoven by The from the concentrated filtrates. This low recovery may ise accounted for by the incomplete elution of the products from silica gel $G$.

As seen in Table 11, no individuel fraction could account for more than 35 percent of the total recovered copper complexing capacity when cells were grown in the absence of copper (fraction $3 a$ contained 32 percent and fraction $9 a$ contained 24 percent of the total recovered capacity). The majority of the fractions complexed less than 5 percent of the total complexing capacity. However, fraction $2 b$ recovered from the filtrate of cell grown in the presence of copper, complexes 40 percent of the total copper complexing capacity recovered. Again, for filtrates 
THE COPPER COMPLEXING CAPACITY OF- SEPARATED FPACTIONS

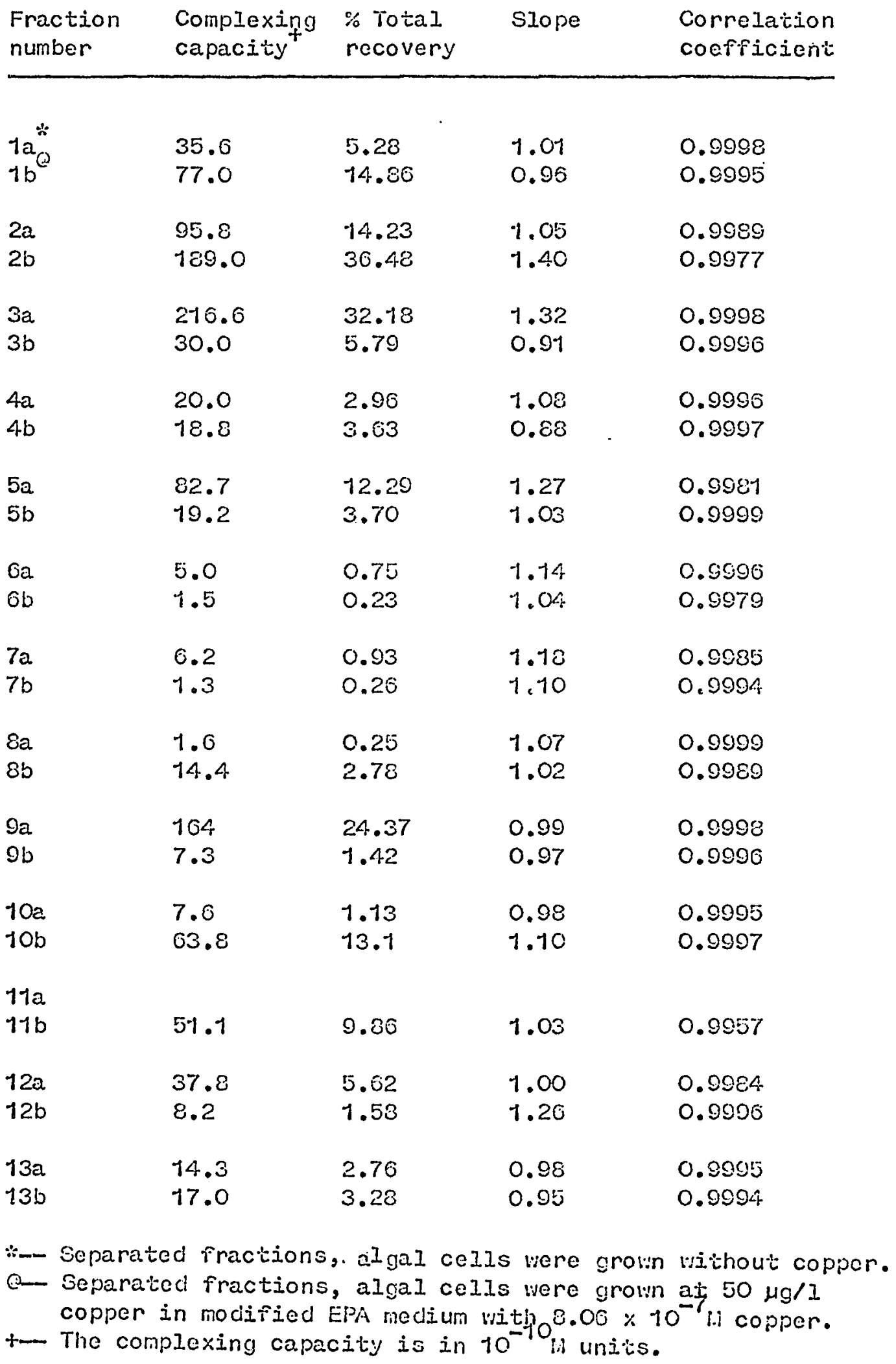


whose cells were initially grown with copper, a majority of fractions complexed less than 5 percent of the total capacity. It can be conclucied from these results that the copper complexing capacities from the tivo sets of separated products, whose cells were grown initially with and without copper, are similar.

VI. DETERIINATION OF CONDITIONAL STABILITY CONSTANTS FOR CONCENTRATED EXTPACELLULAR PRODLCTS

The stoichiometry of metal-ligand complexes is of critical importance in the calculation of conditional stability constants. This stoichionetry can be determined from ljgand titrations (where metal is titrated (ith Iigand) as seen in Appenciix i. Hethods for ligand titrations are found in Methods and haterials (subsection VIIJ.).

The conditional stability constants and average molecular weights for concentrated extracellular producte were cietermined from Scatchard plots. Data needed for scatchard plots are obiained from copper titrations (Iigand titrated with metal) where the ionic copper activity is measured at constant pH and constant total ligand concentration. A derivation of a Scatchard equation for a $i: 1$ metal-liganci system is given in Appendix $C$. The nolecular weight of the Iigand and the conditionel stability constant of the copper-ligand complex can be obtained from the slope and $y$-intercept of Scatchard plots. Scatchard plots have been usec to calculate 
stability constants for copper-ligend complexes associated with natural vaters (Miantoura and Riley, 1975a; Sunde and Hanson, 1978). The calculation of concentrations of soluble copper-hydroxides and copper-carbonates, as a function of $\mathrm{pH}$, is found in Appendix D. Copper-hjdroxice and copper-carbonate species have been elliminated from stability constants. The constants reflect only the exiracellular product complexation.

To test the Scatchard method for detemining copper complexation of solutions, $1 \times 10^{-4}$ M NTA samples were titrated with copper at $\mathrm{pH}$ 4.0. From a linear regression of a Scatchard plot for this titration, correlation coefficient of 0.9986 was obtained, as seen in Fig. 12. From the slope and y-intercept, a molecular Weight of 190.8 and a conditional stability constant of $10^{7.39}$ was calculated. The atomic weight of NTA is 190 and at pit 4.0 the calculated conditional stability constant is $10^{7.48}$ based on constants given in Irving et al. (1987). Thus it is apparent that experimental values close to theoretical can be obtained.

For a mixture of ligands, a conditional stability constant may depend upon the concentration of total ligand and copper. Cheam (1973) and Rarnamoorthy and Kushner (1975) used copper ion selective electrode to measure stability constants for mixtures of ligands. In each case, calculated values of the conditional stability constants changed during the titration. laccarthy (1577; 1979) has determined specific Iimiting conditions where conditional stability constants for mixtures of ligands do not 


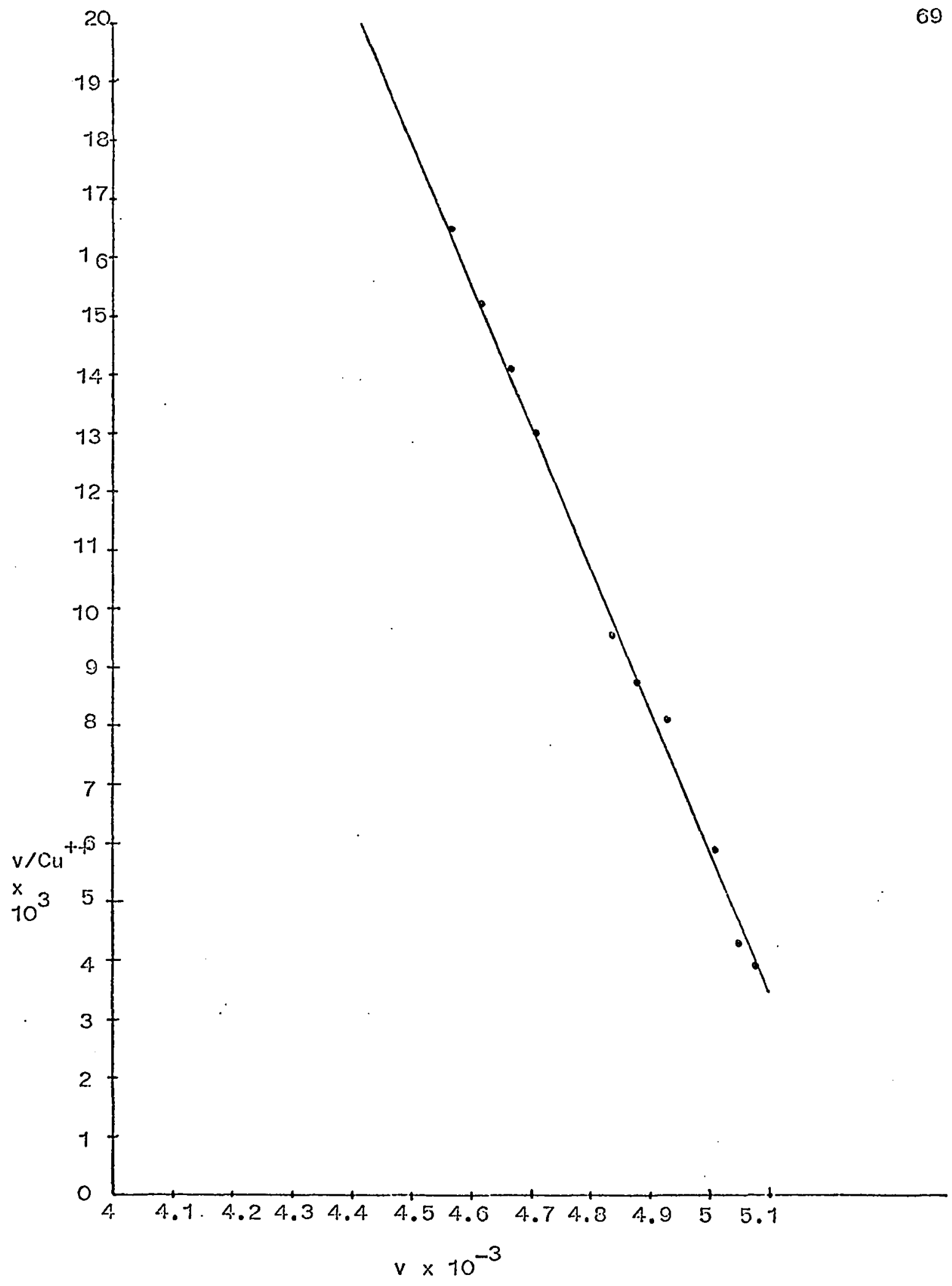

$\frac{\text { Fig: } 12 .}{1 \times 10^{-4} \text { typical Scatchard plot from a solution containing }}$ 
change during a copper or ligand titration. The constants at limiting conditions are called conditional limiting average stability products (C.L.A.S.P.). Two limiting conditions are specified; (1) Shuberi's condition where there is very little linetal present relative to the amount of ligand and, (2) the conditions in which excess metaI is present. Eoth conditions minimizo Jigand competition for the meta.I. Waccarthy et al. (1979) provide mathematical validity for C.L.A.S.P. values in which multiple complexes of different stoichiometries may be involved; however, at the time of this writing only nononuclear complexes are involved in the calculations. Experimentally, Chean (1973) obtained unchanged stability constants (C.L.A.S.P. values) from a copper titration of fulvic acid when the mole fraction of copper was greater than 0.3

Concentrated extraceliular products from $\underline{S}$. capricornutum were titrated with copper. Scatchard plots of these copper titrations produced linear functions over three orders of total copper concentration indicating that the conditional stability constant has reached C.L.A.S.P. values (Fig. 13.). A ratio of 1:1 copperİGand vas detemined using titration data with theoretico.I ca.Icuictions listec in Appendices $E$ and $C$. From the concentrated riltrates of calls grown in the absence of copper, an average conditional stability constant of $3.8 \times 10^{5}\left( \pm 1 \times 10^{5}\right)$ was obtained vith an average nolecular weight of $8.8 \times 10^{4}\left(\div 3 \times 10^{4}\right)$. The following equilibrium is specified for the average conditional 


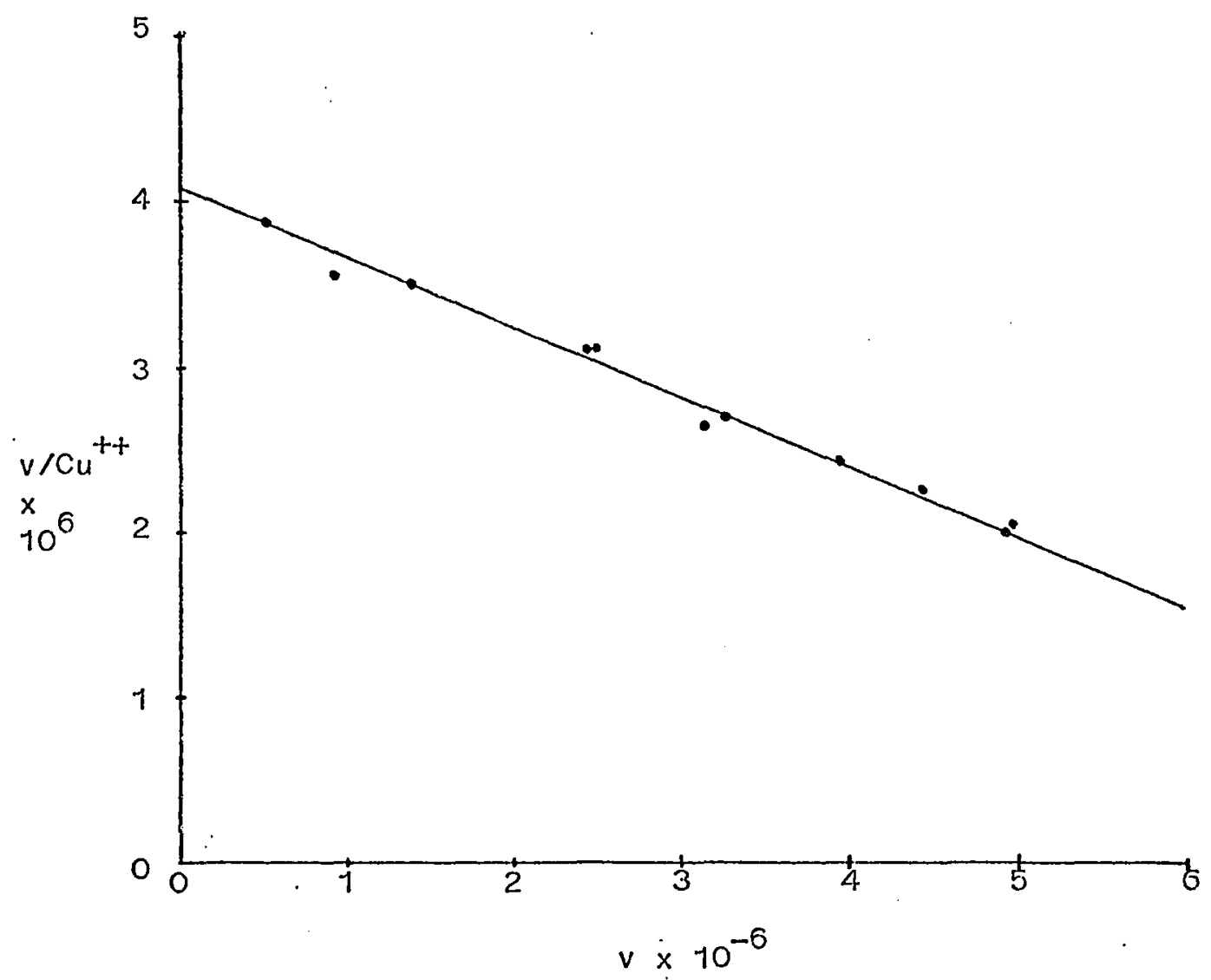

Fig. 13. A Scatchard plot of a solution containing extracej.Iular products from $S$. capricornutum, $p H=5.0$, $1 \times 10^{-1} \mathrm{M} \mathrm{KNO}_{3}$ at pit $5 . \overline{0}$. 
stability constant:

$$
\mathrm{Cu}^{2+}(\mathrm{aq})+\mathrm{H}_{\mathrm{x}} \mathrm{L} \rightarrow \mathrm{CuL}+\mathrm{xH}^{+}
$$

where $H_{X} L$ is the protonated Iigand(s) and CuL is the copper Iigand complex(es). The conditional stability constant is detined as follows:

$$
K_{e}=\frac{E^{*}(1-\alpha)}{\left(H^{+}\right)^{x}}=\frac{(C U L)}{\left(H_{X} L\right)\left(C u^{2+}\right)}
$$

where $k_{e}$ equels the conditional stability constant and $1-\alpha$ is the protonated fraction for the ligand(s). The conditional. stability constants for concentrated filtrates from cells grown in the presence of copper as previously described were measured at 4.7 $\times 10^{5}\left( \pm 1 \times 10^{5}\right)$ with an average molecular weignt of $7.5 \times 10^{5}$ $\left( \pm 2 \times 10^{4}\right)$. A one-tailed t-test was periomed on the two groups of filtrates to see if there was any statistical difference betwcen the two. At the 95 percent conficlence level the two sets were the sarie.

The conditional stability constants for WTA were calculated between $\mathrm{pH} 2.0$ and 4.0 (Fig. 14.) from acid-base titrations in which $\mathrm{Cu}^{2+}$ (aq) was measured with a copper selective electrode at constant total copper and ligand concentrations. The measurement of the conciitional stability consiant is based on the pH, $\mathrm{Cu}^{2+}(\mathrm{aq})$, and total ligand and copper concentrations as shown in Appendix E. Hiethods for acid-base titrations are found in bethocls and ivaterials (subsection VIII). In adciition, theoretical 


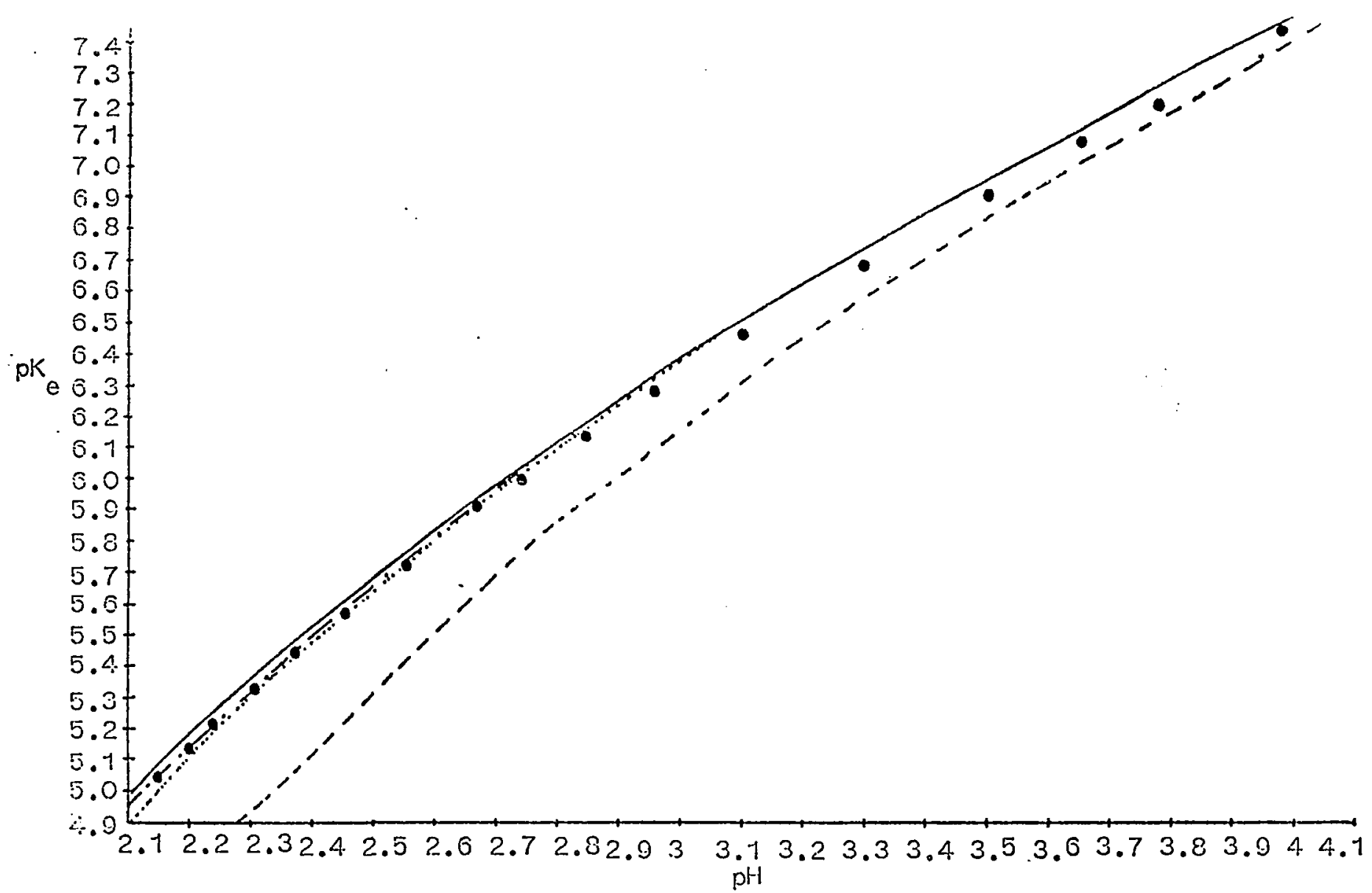

Fig. 14. The conditional stability constants for NTA as a function of pH. Solid and dotted lines represent theoretical caluclations of conditional stability constants whore...... =

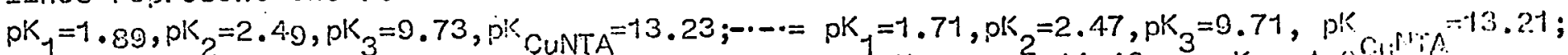

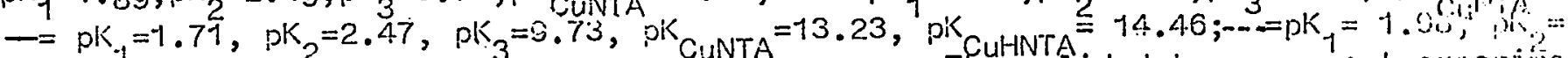

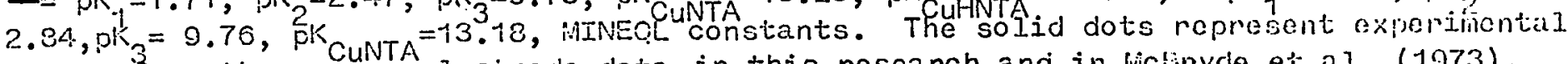
values 3 rom the copper electrode data in this research and in victiryde et al. (1973), $\mathrm{Cu}\left(\mathrm{NO}_{3}\right)_{2}=1.05 \times 10^{-3} \mathrm{M}$ and NTA $=2.11 \times 10^{-3} \mathrm{M}$. 
values for the concitional stability constants of NTA can be cálculated using pie 's and copper-NTA stabilitby constants found in the Iiterature (Irving et al., 1957; Schvarzenbech ct al., i949; Hestall et a.1., 1976; MeEryde et aI., 1973) The derivation of the equation required to calculate conditional staisility constants is in Appendix F. Experimental and theoretical values for the conditional stability constants for MTA verslis phis is given in Fig. 14. Results indicate a close correlotion between the experimental and theoretical values of conditional staibility constants calculated from the $\mathrm{pK}_{a}$ 's deternined by Irving ct aI. (1907) and Schwarzenbach. (1949) and copper-itTA stability constants from McBrycle et al. (1073). However, calculated values based on constants from the data base in the NINECL program (westall et a.., 1976) were lower than the experinental results. Over the entire range of pil, the calculated values underestiriaticd the conditional stability products. From these results it can be seen that a theoretical calculation of a conditional stability constant is only as accurate as the metal-1igand constants used to calculate it.

Acid-base titrations Here also perforned on the concentrated extraceliular fjitrates from S. capricopnutum. The total concentration of copper was $4.0 \times 10^{-5}$ ii and the total concentration of Iigand was $4.4 \times 10^{-5} \mathrm{H}$. As shown in Fig. 15 ., the conditional stability constant remains unchanged over a pli range 


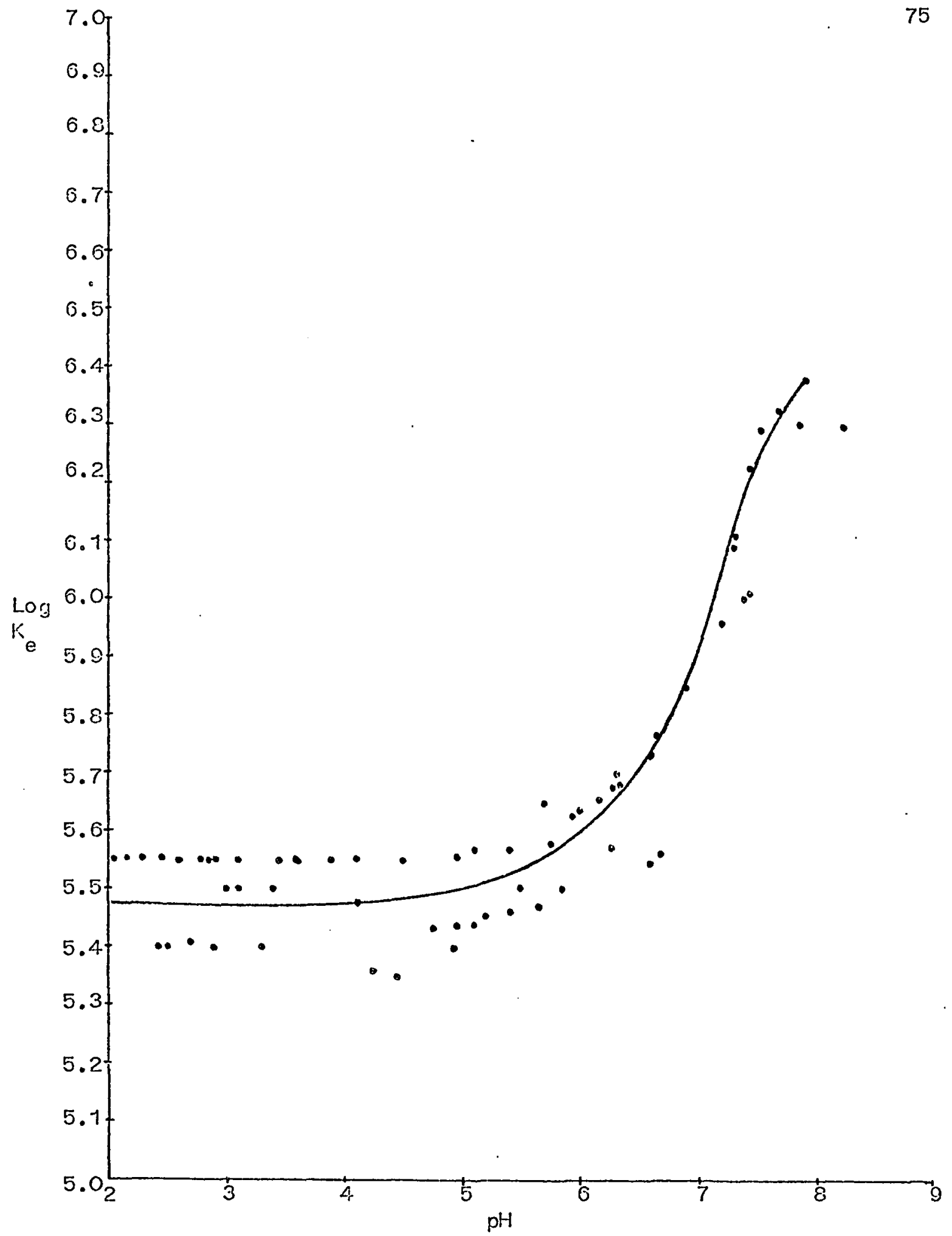

Fig. 15. The conditional stability constants from concentrated extracellular products from 3 . capricornuturn as

a. function of $\mathrm{pH}$. 
from 2.0 to 0.0 and then starts to climi due to decrease in proton competition for the Iigand sites.

The conditional stability constants for three copper ligand complexes are compared with concentrated extracellular filtrates from S. capricornutum over a pH range from 2.0 to 7.0 (Fig. 10.). It appears that the products in the concentrated extracellular filirate have less affinity for copper than cioes NTA, but more than fulvic acid, a class of ligands prevelant in natural waters. This indicates that the conditional stobility constants of the organic matier of extracellular filtrates from $\underline{s}$. capricornutum are of sufficient sirength to effectively compete for copper with many organic and inorganic ligards present in natural waters.

VIT. EFFECT OF COPPER UPTAKE ONI $\mathrm{Cu}^{2+}($ a.q)

Uptake of copper by the bioassay organism may have an affect on $\mathrm{Cu}^{2+}(\mathrm{aq})$ if the aIga is cultured in a weakly metal buffered mediun. Sunda and Guillard (1970) measured the amount of copper taken up by the diatom Thalassiosira pseudonana after three days of growth in a defined seawater medium. At near toxic copper concentrations, the highest measured copper content in I. pseucionana iras $3 \times 10^{-15}$ moles of copper per cell at a. pCu of 8.5 . This cocounts for an uptake of $3 \times 10^{-7}$ moles of copper per liter for culures containing $1 \times 10^{5}$ cells per $\mathrm{ml}$.

The copper content of $\underline{3}$. capricornutum cells was analyzed at iour copper concentrations in modified EPA nediun with 


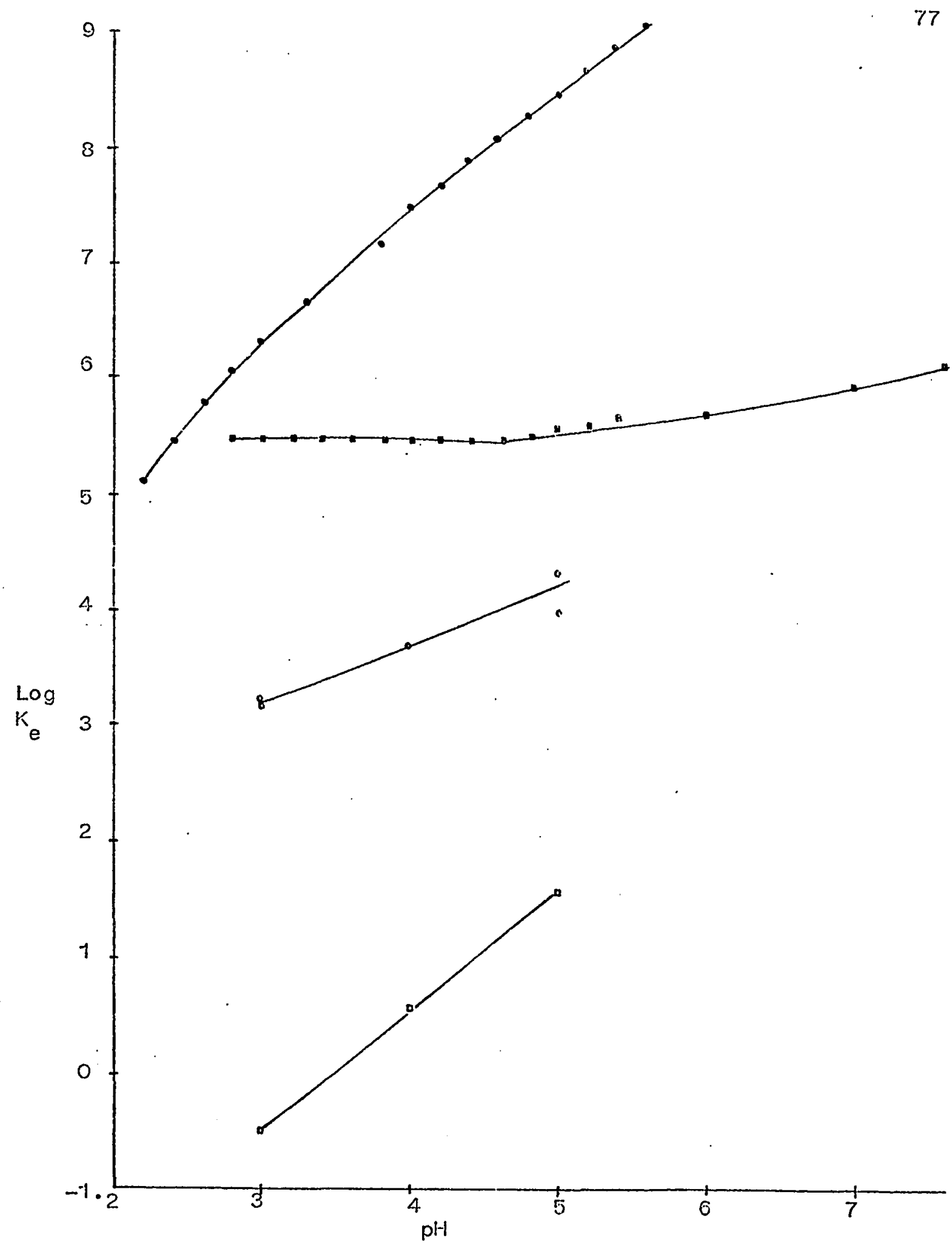

Fig. 10. A comparison of the conditional stability constants for several copper ligand complexes. Symbols represent the following: $\square=$ copper salicylic acid, $0=$ copper fulvic acid, $\bullet=$ copper NTA, = copper products from $\mathrm{S}$. capricornutum, $\square$ and $O$ in Cheam and Gamble (1974). 
$8.00 \times 10^{-7}$ MDTA. Two $\mathrm{pCu}^{2+}$ values for the meciium were decicledly toxic $(7.25$ and 7.39$)$, one morginally algistatic (7.94) and the fourth (8.85) close to the incipient copper concentration. AIgal cells were centrifuged on the second day of the growith period and the copper content of the cells analyzed using flameless atonic absorption. The percent uptake of total copper in the medium as weil as the chenge in $\mathrm{pCu}^{*}$ at the four copper concentrations are listed in Table 12. The change in pcu" was calculated using the MINEQL program (Hestall et al., 1976).

The maximuin concentration of copper taken into $\underline{\text { S. capricornutum }}$ celle was $5 \times 10^{-8}$ moles of copper per Iiter when $1 \times 10^{5}$ cells per ml were present. As seen in Table 12., this is only a fraction of the total copper present in the mecilum. This result shows substantially less copper uptake by $\widehat{S}$. capricornutum than that reported by Suncia and Guillard (1970) for I. pseucionana. Results indicate that even at algistatic copper concentrations the amount of copper taken into cells is less than a few percent of the total copper concentration in the medium and thus the erfect on pCu is minimal.

VITI. THE EFFECT OF SUECULTURE AND NUTRIENT UPTAKE ON COPPER TOLEPANCE IN $\subseteq$. capricornuium

Copper resistance has been demonstrated in Chlorella vulgaris var vulgaris (Fosier, 1977) and Sceneclesmus sp. (Stokes and Hutchinson, 1976). Both algae mere collected in close proxinity to copper mining areas and the concentrations of copper 
THE EFFECT OF COPPER UPTAKE ON PCU" AFTER 3 DAYS OF GROUTH IN MODIFIED EPA MEDTUI, IITTH $8.08 \times 10^{-7}$.. EDTA

Total Copper Percent Copper pCu" before pCu" aficer Concentration uptake inoculation cell growih (molar)

\begin{tabular}{llll}
\hline $6.29 \times 10^{-7}$ & 1.48 & 8.85 & 8.91 \\
$6.20 \times 10^{-7}$ & 1.70 & 8.85 & 8.92 \\
$6.20 \times 10^{-7}$ & 1.10 & 8.85 & 8.80 \\
$7.89 \times 10^{-7}$ & 1.62 & 7.94 & 7.09 \\
$7.89 \times 10^{-7}$ & 1.27 & 7.04 & 7.00 \\
$7.89 \times 10^{-7}$ & 0.75 & 7.04 & 7.97 \\
$9.44 \times 10^{-7}$ & 2.23 & 7.39 & 7.44 \\
$9.44 \times 10^{-7}$ & 2.03 & 7.39 & 7.43 \\
$9.44 \times 10^{-7}$ & 1.31 & 7.30 & 7.42 \\
$1.10 \times 10^{-6}$ & 1.53 & 7.25 & 7.25 \\
$1.10 \times 10^{-6}$ & 4.60 & 7.25 & 7.25
\end{tabular}


found in these waters were much higher than an avorage natural water. Chlorella vulgaris was isolated from the River Hayle which drains abancioned copper mines in Cornwall, England. Sceneciesmus sp. was isolated in Eoucher Lake which is close to the Sudbury, Ontario smelters. The whole region is a mining and smelting region for nickel and copper. Stokes and Hutchinson (1976) and Foster (1977) have shoun that these algae are able to tolerate more copper than their equivalent laboratory sirains. The copper resistance in these species strongly indicates genetic adaptation. Comparing copper content of algal pellets from $\underline{C}$. vulgaris with its equivalent Iaboratory strain at one growtin rate, Foster (1977) found the same amount of intracellular copper. This indicates, for $\underline{C}$ vulgaris, thet copper tolerance is due either to the production of some extracellular products or the development of some copper exclusion mechanism. The release of metabolites which accumulate in algal cells may be due to mutation by the loss of a control mechanism in a specific metabolic pathway (Hellebust, 1974). It is possible that selection for this mutation occurs uncier high metal stress conditions.

To test for the selection of a genetic change in copper tolerance, S. capricornutum l:as examined by subculturing six day old cells from the copper bioassay experiment into fresh modified EPA medium at the same pCu and chelator concentrations. Growth rates were compared to values obtained on the previous nedium (Fig. 17.). Resuits show that the growth rate of transferred cultures were 


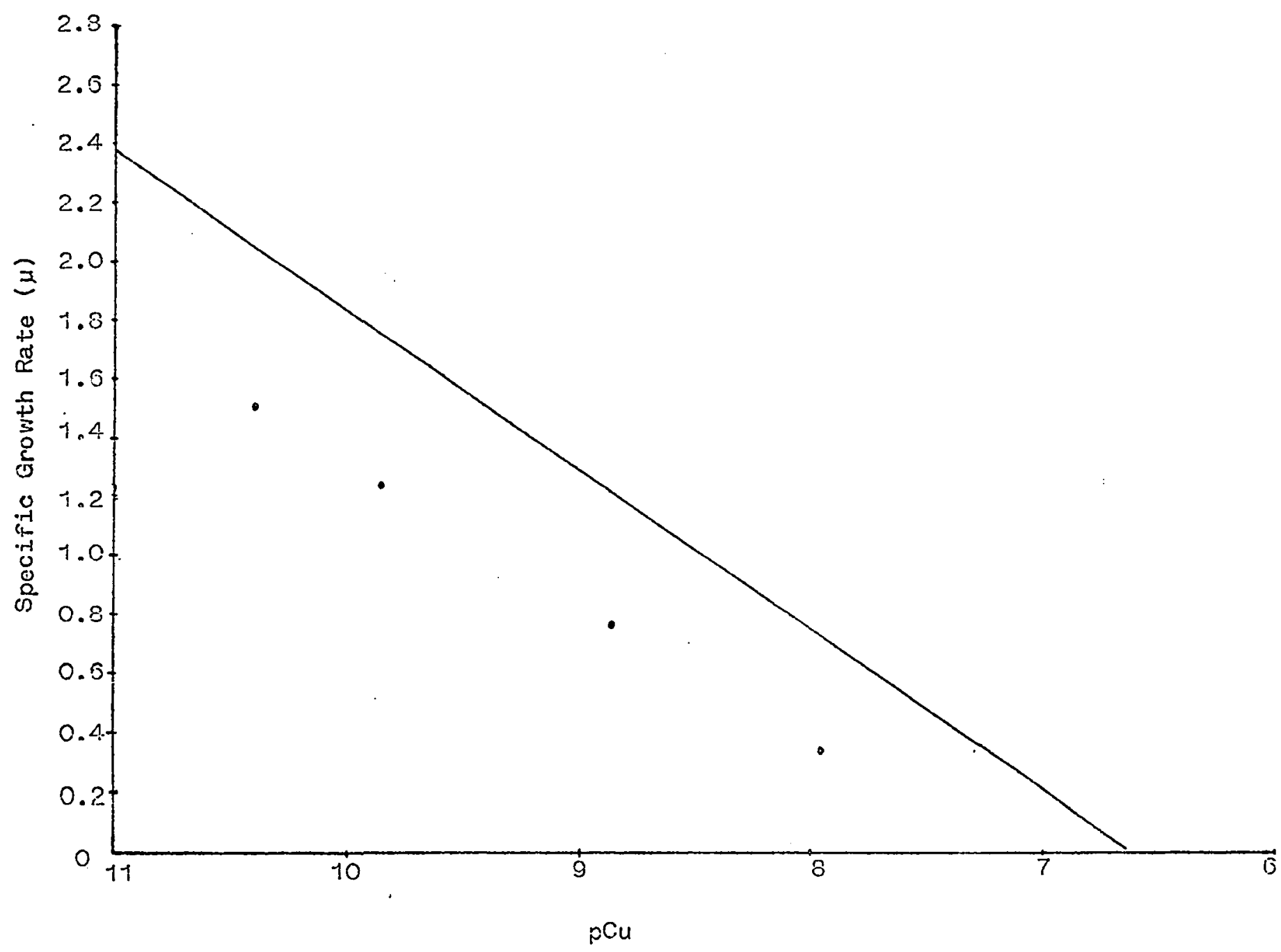

Figure it. The offect of subculturins on $\mu$; the solid line represents the linear relationship established between growth rate and $\mathrm{pCu}$ for $\mathrm{s}$. capricornutum from data obtained in the copper bioassay experiment. The dots represent récultured cells from that experiment. 
lower than those initially grown. The lower growth rate for subcultured cells nay be due to an increase in internal copper concentration or the accunulation of copper on the outside of the cell wall preventing cell division (Steemann-fiejsen and lium-Anderson, 1970). Stokes and Hutchinson $(1970)$ and Hassal (1963) heve ciemonstrated that algae accumulate copper interneliy over time at high pCu. In conclusion, the hypothesis of copper adaptation has not been confirmed for this species. In other research, evicience suggests that the length of exposure to $p C u$ is another factor in cotermining toxicity.

SeIenastrum capricornutum is sensitive to copper ion activity based on the evidence from the copper bioassay experinent. Since a change in ionic strength can affect ion activity (Debye-tuckel) it becane important to investigate nutrient uptake during the grolvth of $\subseteq$. capricornutlim in batch culture. The major ions responsible for contribution to ionic sirength were measured on each of four ciays according to procedures in ilethod and Materials (subsection XIII.). The ionic strength of the complete medium and the concentration of the various anions anci cations versus the days of growth are listed in Tables 13 and 14 . The major ions are conp]etely ionized in the modified EPA medium as indicated from the MINEQL progran (Lestall et al., 1976). Thus the calculation of ionic strength was based on the total ion concentrations. The results shown in Tables 13 , and 14 , inciicate that the ionic sitrength 
TABLE VIII

NUTRIENT UPTAKE EXPERIMENT: THE VARIATION OF CATIONS AND IONIC STRENGTH OVER A FOUR DAY GROHTH PERIOD.

\begin{tabular}{|c|c|c|c|c|c|}
\hline $\begin{array}{l}\text { Tjme } \\
\text { days }\end{array}$ & $\begin{array}{l}\text { potassium } \\
\times 10^{-5} \mathrm{M}\end{array}$ & $\begin{array}{l}\text { sodium } \\
\times 10^{-4}\end{array}$ & $\begin{array}{l}\text { magnesium } \\
\times 10^{-5} \mathrm{M}\end{array}$ & $\begin{array}{l}\text { calcium } \\
\times 10^{-5}\end{array}$ & $\begin{array}{l}\text { Ionic strength } \\
\times 10^{-4} \text { in }\end{array}$ \\
\hline 0 & 1.68 & 4.89 & 1.48 & 2.00 & 9.44 \\
\hline 0.04 & 1.33 & 3.84 & 1.27 & 1.80 & 0.15 \\
\hline 1 & 1.12 & 4.05 & 1.48 & 1.60 & 5.20 \\
\hline 2 & 1.30 & 6.65 & 1.36 & 2.14 & 6.50 \\
\hline 3 & 1.12 & 3.44 & 1.48 & 2.03 & 5.50 \\
\hline 4 & 1.40 & 3.44 & 1.44 & 2.29 & 5.75 \\
\hline
\end{tabular}


TABLE YTV

MUTRIENT UPTAKE EXPERIMENT: THE VARIATION OF ANIONS OVER A FOUR DAY GROHTH PERIOD.

\begin{tabular}{|c|c|c|c|c|c|}
\hline $\begin{array}{l}\text { Time } \\
\text { days }\end{array}$ & $\begin{array}{l}\text { sulfate } \\
\times 10^{-5} \mathrm{M}\end{array}$ & $\begin{array}{l}\text { carbonate } \\
\times 10^{-7}\end{array}$ & $\begin{array}{l}\text { nitrate } \\
\times 10^{-5} \mathrm{M}\end{array}$ & $\begin{array}{l}\text { chioride } \\
\times 10^{-4} \mathrm{~m}\end{array}$ & $\begin{array}{l}\text { bicarbonate } \\
\times 10^{-4}\end{array}$ \\
\hline 0 & 22.0 & 2.08 & 6.85 & 2.16 & 1.40 \\
\hline 0.04 & 7.23 & 2.08 & 8.80 & 1.05 & $i .40$ \\
\hline 1 & 3.10 & 2.08 & 3.65 & 2.01 & 1.40 \\
\hline 2 & 4.69 & 2.08 & 2.10 & 1.50 & 1.40 \\
\hline 3 & 3.98 & 5.22 & 1.65 & 2.04 & 2.22 \\
\hline 4 & 3.59 & 8.28 & 1.11 & 2.07 & 2.80 \\
\hline
\end{tabular}


did not change enough to affect the copper ion activity coefficient during the growth period. Even if the ionic strength has been substantially reduced due to nutrient uptake, tirere would be only a 12 percent increase in the copper activity cocfficient based on data given in Kielland (1937). 


\section{SUATIARY AND CONCLUSIONO}

Copper toxicity to the green alga, Selenastrum capricornutum was investigated. Two general areas of inquiry have been studied. The first question acidressed was-nhat form of copper is toxic to the a.Iga? Results indicate that ionic copper is the toxic form. The ionic copper concentration $\mathrm{Cu}^{2+}(\mathrm{aq})$ in each medium used was buffered by EDTA or NTA. Growth rates were calculated between the second and third days of growth. The ionic copper concentration in each medium used was calculated using the computer program, MINEQL. A linear relationship was established between growth rate and the log of the calculated ionic copper concentration (pCu*), but no relationship between the log of the total copper concentration and growth rate was found. This result shows that it is the ionic form of copper that is toxic to Selenastrum capricornutum. In comparison with 30 other algal species, S. capricornutum was found to be a copper resistant species.

The second question addressed was-m-Does the concentration of ionic copper, $\mathrm{Cu}^{2+}(\mathrm{aq})$, change during log phase grovith of $\underline{\mathbf{s}}$. capricornutum? $\mathrm{A}^{-14} \mathrm{CO}_{2}$ uptake experiment showed that $\mathrm{S}$. capricornutum produced extracellular organic products in log phase of growth which amount to three percent of the total fixed carbon. Extracellular organic products were concentrated on WAD- 8 Amberite (a macroreticular non-ionic exchange resin). Two filtrates vere concentrated: one filtrate vas obtained from algae which were 
cultured in the absence of acided copper and the second filtrate was obtained from algae which were cultured at near toxic copper concentrations. The copper complexing capacity, conditional stability constants and average molecular weights for these concentrated organic products were calculated from data obtained by use of a copper ion selective electrode. In addition, the concentrated organic products from the two algal filtrates were separated by thin layer chromotography into 11 to 13 fractions and the copper complexing capacity of each individual fraction was determined.

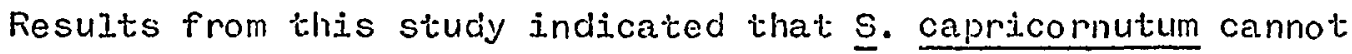
be induced to produce a new product or to increase its copper complexing capacity by culturing cells in the presence of increasing concentrations of copper. The copper complexing capecity of the extraceliular products in concentrateo fiztrates was $2.1 \times 10^{-7}$ $\left( \pm 8 \times 10^{-8}\right) \mathrm{M}$. The concitional stability constant was round to be $10^{5.55}$ between $\mathrm{pH} 2.0$ to 6.0 . An average molecular weight of $8.8 \times 10^{4}\left( \pm 3.4 \times 10^{4}\right)$ was obtained for these products.

The $\mathrm{pH}$ is another factor which could change pCu during the log phase growth of $\underline{S}$. capricornutum. The pH of some cultures in the copper bioassay experiment may increase as much as 0.4 $\mathrm{pH}$ units by the second or third day of grovith. This is due in part to carbonate and bicarbonate ion uptake by the algae. This pll change affects the ionic copper concentration through the conversion of ionic copper to copper hydroxide. A calculation of ionic copper concentration can be obtained at any $\mathrm{pH}$ in a 
defined medium with the MINEQL computer program. The pil of each culture was experimentally measured and at the experimental pit of the culture, ionic copper concentrations were calculated. Retween most replicate cultures, the variation in $\mathrm{pH}$ caused less than a two-fold change in $\mathrm{Cu}^{2+}(\mathrm{aq})$ concentration.

Copper uptake by the alga during growth in batch culture had a marginal effect on $\mathrm{pCu}$. A copper bioassay experiment was duplicated using modified EPA medium with $8.00 \times 10^{-7}$ i EDTA. Selenastrum capricornuturn celis were collected on the third day of the growth period. This growth period was the interval of time over which the growth rate was calculated. Total copper content of the cells was determined using fiameless atomic absopption spectroscopy. At toxic copper concentrations, 1.75 percent of the total copper vas found in the cells. This uptake of copper changed pCu ${ }^{*}$ from 7.38 to $7.43( \pm 0.01)$. Ethylenediaminetetraacetic acid uptake, previous growth of cells in the presence of copper, and nutrient uptake by $\underline{3}$. capricornutum had little or no affect on pCu during the log phase growth period.

The algistatic affects of copper are totally reversible at aII copper concentrations used in these copper bioassays. Cells were taken from 7 day cultures which had been grown at various pou's in the copper bioassay experiments. Each set of cells was spreyed onto agar containing modified EPA medium with $8.06 \times 10^{-7} \mathrm{M}$ EDTA (but no added copper) and the percent cells undergoing division were recorded at 24 hour intervals for three days. Results show that all cells were undergoing division by the second or third day 
regardless of the concentration of copper present in the previous growth medium. It is evident that a $\mathrm{pCu}$ level can be used to predict the growth rate of an a.lga.

Since the pcu-dependent growth rate of S. capriconnutum is relatively unaffected by other factors in the growth medium, this organism would be particularly effective as a test organism for monitoring pCu. In addition, a copper bioassay, similar to those described in this research, could be performed on any natural water using the natural phytoplankton from that vater. A copper complexing capacity for that netural water could be obtained. If the primary productivity of an eutrophic natural water needesi to be reciuced with the standard treatment of copper sulfate, the quantity needed to effect a change could be based on this copper complexing capacity. Thus, copper bioassays could predict the best concentration of copper in controlling the algal growich in natural waters. 


\section{REFERENICES}

Aaronson, S., B. DeAngelis, O. Frank, and H. Baker. 1971. Secretions of Vitamins and Amino Acids into the Environment by Ochromonas damica. J. Phycol. 7: 215-218.

Alexander, J.E., and E. F. Corcoran. 1967. The Distribution of Copper in Tropical Seawater. Limnol, Oceanogr. 12: 236-242.

Anderson, D. M., and F. M. M. Morel. 1078. Copper Sensitivity of Conyaulax tamarensis. Limnol. Oceanogr. 23: 283-295.

Andrew, R. W., K. E. Biesinger, and G. E. Glass, 1976. Effects of Inorganic Complexing on the Toxicity of Copper to Daphnia magna. liater Res. 11: 309-315.

Anonymous. 1971. Sumnary Bulletin Amberlite Polymeric Adsorbents. Rohm and Haas Co., Philadelphia, Pa.

Barber, R. T. 1973. Organic Ligands and Phytoplankton Growth in Nutrient-Rich Seawater. p. 321-338. In P. Singer (ed.). Trace Netals and Metal-organic Interactions in Natural laters. Ann Arbor Sci.

Eaptlett, L., F. W. Rabe, and W. H. Funk. 1973. Effects of Copper, Zinc and Cadmium on Selenastrum capricornutuin. Water Res. 8: $179-185$.

Eartjey, T. R. 1976. Investigations of Copper Sulfate for Aquatic Veed Control. U.S.D.I. Bureau of Reclamation Report No. 27.

Elaedel, W. J., and D. E. Dinwiddie. 1974. Study of the Behavior of Copper Ion-Selective Electrodes at Submicromolar Concentra.tion Levels. Anal. Chem. 46: 373-877.

Buffle, J., F. Greter, and W. Haerdi. 1977. Measurement of Complexation Properities of Humic and Fulvic Acids in Natura? Viaters with Lead and Copper Ion-Sels:ctive Electrodes. Anal. Chem. 49: 216-222.

Eutton, K. S., and H. P. Hostetcer. 1977. Copper Sorption and Release by Cyclotella meneghiniana (Bacellariophyceae) and Chlamydomonas reinharditi (Chlorophyceae). J. Phycol. 13: 198-202.

Cheam, V., and D. S. Gamble. 1974. Metal-Fulvic Acid Chelation Equilibrium in Aqueous $\mathrm{NaNO}_{3}$ Solution $\mathrm{Hg}$ (II), $\mathrm{Cd}$ (II), and Cu(II) Fulvate Complexes. Can. J. Soil Sci. 54: 413-417. 
Cheam, V. 1973. Chelation Study of Copper(II): Fulvic Acid System. Can. J. Soil Sci. 53: 377-332.

Chiaudani, G., and ii. Vighi. 1977. The Use of Selenastrum capricornutum Batch Culture in Toxicity Studies. Mitt. Int. Ver. Theor. Angew. Limno 1. 21: 316-320.

Clesceri, N. L., G. C. McDonald, I. J. Kumar, and H. J. Green. 1973. Organic Nutrient Factors Effecting Algal Growthb EPA-600/3-73-003. U. S. Environmental Protection Agency.

Craigie, J. S., J. Miclachlan, H. Majak, R. C. Ackman, and C. S. Tocher. 1906. Photosynthesis in Algae II. Green Algae with Special. References to Dunaliella spp. and Tetraselmis spp. Can. J. Eot. 44: 1247-1254.

Davey, E. W., M. J. Worgan, and S. J. Erickson. 1973. A Biological Measurement of the Copper Compleration Capacity of Seavater. Limno 1. Oceanogr. 18: 993-997.

Erickson, S. J. 1972. Toxicity of Copper to Thalassiosira pseudionana in Unenriched Inshore Seavater. J. Phycol. 8: 318-323.

Fitzgerald, G. P. 1564. Factors in the Testing and Application of Algicides. Appl. Microbiol. 12: 247-253.

Fitzgerald, G. P., and S. L. Faust. 1963. Factors Affecting the Algiciclal and Algistatic Properities of Copper. Appl. Microbiol. 11: 345-351.

Fogg, G. E. 1978. Excretion of Organic Matter by Phytoplankton. Limnol. Oceanogr. 22: 576-577.

Fogg, G. E. 1971. Extracellular Products of Algae in Fresh Viater Arch. Hydrobiol. 5: 1-25.

Fogg, G. E. 1966. The Extracellular Products of Algae. Oceanogr. Mar. Eiol. Ann. Rev. 4: 195-212.

Fogg, G. E. 1902. Extracellular Products. p. 475-489. In R. A. Lewin (ed.), Physiology and Biochemistry of Algae. Academic Press.

Fogg, G. E., and D. F. Westlake. 1955. The Importance of Extracellular Products of Algae in Freshwater. Ver. Int. Ver. Limnol. 12: $219-232$.

Foster, P. L. 1977. Copper Exclusion as a Mechanism of Heavy Metal Tolerance in a Green Alga. Nature(Lond.) 2.69: 322-323. 
Gachter, R., K. Lum-Shue-Chan, and Y. K. Chau. 1973. Complexing Capacity of the Nutrient liedium and its Relation to Inhibition of Algal Photosynthesis by Copper. Schweiz. Z. Hydrol. 35: $252-261$.

Gamble, D. S., H. Schnitzer, and I. Hoffmann. 1970. Cu $\mathrm{Cu}^{2+}$-Fulvic Acid Chelation Equilibrium in $0.1 \mathrm{~m} \mathrm{KCL}$ at $25.0 \mathrm{C}$. Can. J. Chem. 48: 3197-3204.

Gardiner, J. 1975. Complexation of Trace Hetals by Ethyleneciaminetetraacetic Acid (EDTA) in Natural Waters. Water Res. 10: $507-514$.

Gibson, C. E. 1972. The Algicidal Effect of Copper on a Green and a Elue-Green Alga and some Ecological Implications. J. Appl. Ecol. 9: 513-518.

Gillespie, P. A., and R. F. Vaccaro. 1978. A Bacterial Bioassay for Weasuring the Copper-Chelation Capacity of Seavater. Limno 1. Occanogr. 23: 543-548.

Gocke, K. 1970. Untersuchungen über Abgabe und Aurnahme von Aninosäuren und Polypeptiden durch Planktonorganismen. Arch. Hycirobio1. 67: 235-367.

Goldman, J. C., H. J. Osivald, and D. Jendins. 1974. The Kinetics of Inorganic Carbon Limited Algal. Grolith. J. Hater Pollut. Control. Fed. 46: 554-573.

Guillard, R. R. L., and J. A. Hellebust. 1971. Growth and the Production of Extracellular Substances by Two Strains of Phaeocystis poucheti. J. Fhycol. 7: 330-338.

Hassall, K. A. 1903. Uptake of Copper and its Physiological Effects on Chlorella vulgaris. Physiol. Plant. 16: 323-332.

Hellebust, J. A. 1974. Extracellular Products. p. 838-863. In W. D. P. Stewart (ed.), Algal Physiology and Biochemistry, Botanical Monograms v. 10. U. Cal. Press.

Irving, H. M., M. G. Miles, and L. D. Pettit. 1967. A Siudy of Some Problems in Deternining the Stoicheiometric Proton Dissociation Constants of Complexes by Potenitionetric Titrations using a Glass Electrode. Anal. Chem. Acta. 38: $475-4.33$.

James, D. E. 1971. Isolation and Putification of Algae, Dept. Carolina Biological Supply Co. Durlington North Carolina 9: $33-35$. 
Jasinski, R., I. Trachtenberg, and D. Andrychuk. 1974. Potentiometric Hoosurement of Copper in Seavater with Ion Belective Electrodes. Anal. Chem. 46: 364-369.

Johansson, G. and K. Edstrom. 1972. Studies of Copper(II) Sulphicie Ion-Selective Electrodes. Talanta 19: 1523-1632.

Jones, R. F. 1952. Extracellular Mucilage of the Red Alga Porphyridium cruentum. J. Celz. Comp. Physiol. 60: 61-64.

Kennish, J. M. 1978. Trace Metal Jon Activities from LiquidLiquidd Partitioning heasurements. Doctorial Dissertation. Portland State University, $100 \mathrm{p}$.

Kielland, J. 1937. Individual Activity Coefficients of Ions in Aqueous Solutions. J. Am. Chem. Soc. 59: 1675-1678.

Kimball, K. D. 1973. Seasonal Fulctations of Ionjc Copper in Knights Pond, Massachusetts. Limnol. Oceanogr. 18: 169.172.

King, D. L. and J. T. Kovak. 1974. The Kinetics of Inorganic Carbon-Limited Algal Growth. J. Water Pollut. Control. Fed. 46 : $1812-1810$.

Lewin, R. A. 1956. ExtraceIIular Polysaccharides of Green AIgae. Can. J. lilj.crobiol. 2: $665-672$.

MacCarthy, P., and G. C. Smith. 1979. Stability Surface Concept A Quantitative Model for Complexation in Multiligand Mixtlires. ACS Symp. Ser. Chem. Model. Aqueous Syst.: Speciation, Sorption, Solubility, Kinet. 93: 201-222.

MacCarthy, P. 1977. An Interpretation of Stability Constants for Soil Organic Matter-lletal Ion Complexes under Shubert Conditions. J. Environ. Sci. Health Part A 12: 43-59.

Haloney, T. E., and E. M. Palmer. 1956. Toxicity of Six Chemical Compounds to Thirty Cultures of Algae. Hater Sewage llorks 102: $509-513$.

HandeIli, E. F. 1969. The Inhibitory Effects of Copper on Warine Phytoplankton. Contr. Mar. Sci. 14: 47-57.

Majak, W., J.S. Craigie, and J. Mclochlan. 1966. Photosynthesis in AlgaeI: Accumulation Products in the Rhodophyceae. Can. J. Bot. 44: 541-549.

Mantoura, R. F. C., and j. P. Riley. 1975a The Use of Gel Filtration in the Study of Metal Einding by Humic Acids and Related Compounds. Anal. Chim. Acta. 78: 193-200 
Mantoura, R. F. C., and J. P. RiJey. 1975b. The Analytical Concentration of Humic Substances from latural laters. Ana.J. Chim. Acta. 70: $97-100$.

McBryde, W. A. E., and J. L. McCourt, and V. Cheam. 1973. Copper (II)-Nitrilotriacetate Complexes in Aqueous Solutions. J. Inorg. Nucl. Chem. 35: 4193-4197.

McDuff, R. E., and F. M. Norel. 1973. Description and Use of the Chemical Equilibrium Program REDEQL2. Tech. Rep. EQ-73-02, Keck Lab., Cal. Inst. Technol. $75 p$.

Miller, H.E., J. C. Greene and T. Shiroyama. 1976. Use of Alga.l Assays to Define Trace-Element Limitation and Heavy iletal Toxicity. Proceeding: Terrestrial and Aquatic Ecological Studies of the Northwest Symposium. Eastern Washington State College, Cheney, lashington.

Miller, W. E., J.C. Greene, and T. Shiroyarna. '1975. Application of Algal Assay to Define the Effects of llastewater Effluents upon Algal Growth in Multiple Use River Systems. Proc. Biostinulation and Nutrient Assessment Workshop. Nov. 1975, Utah State Universjty, Logan, Utah p. 77-92.

Miller, W. E., T. E. Maloney, and J. C. Greene. 1974. Algal. Productivity in 4.9 Lake Vlaters as Determined by Algal Assays. Hater Res. 8: 667-679.

Hoore, B. G., and F. G. Tischer. 1965. Biosynthesis of Extracellular Polysaccharides by the Blue-Green Alga Anabaena flos-aquae. Can. J. Microbiol. 11: 877-885.

Morel, N.M. L., J. G. Rueter, and F. H. M. Morel. 1978. Copper Toxicity to Skeletonema costaturn (Bacillariophyceae). J. Phycol. 14: 4.3-48.

Norel, F., and J. Morgan. 1972. A Numerical Method for Computing Equilibria in Aqueous Chemical Eystems. Environ. Sci. Technol. 6: 58-67.

Prager, J. C., J. iA. Burke, J. Marchisotto, J. J. A. McLaughlin. 1959. Mass CuIture of a Tropica. Dinoflagellate and the Chromatographic Analysis of Extracellular Polysaccharides. J. Protozool. 6(suppl.): 19-20.

Ramamoorthy, S., and D. J. Kushner. 1975. Heavy Metal Binding Components of River Water. J. Fish. Res. Board Can. 32: $1755-1766$. 
Riley, J. P., anci P. Taylor. 1971. The Analytical Concentration of Traces of Dissolved Organic llaterials from Seawater with Amberlite XAD-1 Resin. Anal. Chim Acta 46̈: 307-309.

Rounsefell, G. A., and J. E. Evans. 1958. Large-Scale Experimental Test of Copper Sulfate as a Control for Florida Red Tide. U. S. Fish Wildl. Spec. Sci. Rep. Fish. No. 270.

Schindler, D. W. and S. K. Holmgren. 1971. Primary Production and Phytoplankton in the Experimental Lo.kes Area, Northwestern Ontario, and other Lov-Carbonate liaters, and a Liquid Scintillation Method for Determining ${ }^{4} \mathrm{C}$ Activity in Photosynthesis. J. Fisherjes Res. Eoard of Can. 28: 189-291.

Schwarzenbach, G., H. Ackermann, and P. RuckstuhI. 1949. Neue Derivate der Imino-diessigsäure und ihre Erdalkalikomplexe Beziehungen zwischen Acidität und Kimplexbildung. Helv. Chimi Acta. 32: 1175-1186.

Shakerin-Sweet, M. 1979. Personal Cormunication, Portland State University.

Sharp, J. H. 1978. Reply to Comment by S. Aaronson. Limnol. Oceanogr. 23: 839-840.

Sharp, J. H. 1977. Excretion of Organic Matter by Marine Phytoplankton: Do Healthy Cells do it? Limnol. Oceanogr. 22: 381-399.

Shuman, M. S., and G. P. Vioodward Jr. 1973. Chemical Constants of Hetal Complexes from a Compleometric Titration Followed with Anodic Stripping Voltammetry. Anal. Chem. 45: 2032-2035.

Sillén, L. G., and A. E. Martell. 1971. Stability Constants of Metal-Ion Complexes. Suppl. No. 1. Special Publ. No. 25. Chemical Society. London.

Sillén, L. G., and A. E. Martell. 1964. Sitability Constants of Metal-Ion Complexes, Special Publ. No. 17. Chemical Society. Loncion.

Snycler, L. R. TS68. Principles of Adsorption Chromatography; The Separation of Nonionic Organic Compounds. 3. Dekker.

Steemann-Nielsen, E., and S. Vium-Aindersen. 1970. Copper Ions as Poison in the Sea and in Freshwater. War. Biol. (W.Y.) 6: $93-97$. 
Steemann-Nielsen E., L. Kamp-Nielsen, and S. Wium-Andersen. 1909. The Effect of Deleterious Concentrations of Coprer on the Photosynthesis of Chlorella pyrenoiciosa. Physiol. Plant. 22: 1121-1133.

Stiff, M. J. 1971. Copper/Bicarbonate Equilibria in Solutions of Bicarbonate Ion at Concentrations Similar to those found in Natura? laters. Water Res. 5: 171-176.

Stokes, P., and T. C. Hutchinson. 1976. Copper Toxicity of Phytoplankton as Affected by Organic Ligands, Other Cations and Inherent Tolerance of Algae to Copper, p. 159-185. In R. 1. Andrew, P. V. Hocison and D. E. Konasewich (eds.), Toxicity of Biota of Metol Forms in Nature: l laters. Proceeding of liorkshop, Great Lakes Advisory Eoard International Jojnt Commission, Duiuth Minnesota.

Surda, W. G. 1975. The Relationship bettveen Cupric Ion Activity and the Toxicity of Copper to Phytoplankton, Doctorial Dissertation, Mass. Instit. Technol., $167 \mathrm{p}$.

Suncia, H. G., and P.J. Hanson. 1978. Chemical Speciation of Copper in River later: Effect of Total Copper, pli, Carbonate and Dissolved Organic Watter. P. 100-103. Amer. Chen. Soo. Div. of Environ. Chem., Miami Eeach Fl.

Sunda, W. G., and JoAnn H. Lewis. 1970. Effect of Complexation by Natural Organic Ligands on the Toxicity of Copper to a. Uniceliular Alya, Monochrysis Jutheri. Linnol. Oceanogr. 23: $870-876$.

Sunck, H. G., and F. R. L. Guillard. 1970. The Relationship between Cupric Ion Activity and the Toxicity of Copper to Phyioplankton. J. Mar. Res. 34: 511-529.

Gwallow, K. C., J.C. Hestall, D. M. Mcknight, N. M. L. Morel, and F. M. M. Horel. 1978. Potentionetric Determination of Copper Complexation by Phytoplankton Exuclates. Limnol. Occanogr. 23: $538-542$.

Sylva, R. N. 1975. The Environmental Chemistry of Copper(II) in Aquatic Systems. !later Res. 10: 789-792.

Taras, M. J., 1971. Standard Methods for the Examination of liater and liastevater (13th ed.). Aner. Publ. Health Assoc.

Thomas, W. H., O. Holm-Hansen, D. L. R. Siebert, F. Azam, R. Hodson, and ii. Takahashi. 1977. Effects of Copper on Phytoplankton Stanciing Crop and Productivity: Controlled Ecosystem Pollution Experiment. Eull. Har. Sci. 27: 34-43. 
Thomas, W. H., and D. L. R. Seibert. 1977. Effects of Copper on the Dominance and the Diversity of Algae: Controlled Ecosystom Pollution Experiment. Bull. ilar. Sci. 27: 23-33.

Toerien, D. F., and C. H. Huang. 1973. Algal Growth Prediction using Kinetic Constants. Uater Res. 7: 1673-1681.

vatt, W. D., and G. E. Fogg. 1965. The Kinetics of Extraceliular Glycollate Production by Chlorella pyrenoidosa. J. Exp. Bot. 17: 117-134.

Wleinmann, G., 1970. Gelöste Kohlenhydrate und andere Organische Stoffe in Naturlichen Gewässern und in kulturen von Scenedesmus quadricauda. Arch. Hydrobiol. Supplementcb. 37: 104-24.2.

lieiss, C. M., and R. W. Helns. 1971. The Interlaboratory Precision Test: An Eight Laboratory Evaluation of the Provisional Algal Assay Procedure Bottle Test. EPA-Water Quality Office Project-10010D?T.

Hestall, J.C., J. L. Zachary, and F. H. M. MoreI. 1976. MINEQL: A Computer Progran for the Calculation of Chemical Equilibrium Composition of Aquatic Systems. Dept. of Civil Eng. Tech. note No. 18. Nass. Instit. Technol. 


\section{APPENDIX A}

GENERATION TIME AND DOUBLINGS PER UNIT TIRE AS A FUNCTION OF THE SPECIFIC GROLTHH RATE CONSTANT

The specific growth rate constant is defined as follows:

$$
\mu=\frac{1}{t^{-t}-1}\left\{\ln \left\{\frac{N_{2}}{N_{1}}\right\}\right\}
$$

where $N_{4}$ and $N_{2}$ are the population sizes, in cells per mil, at time $t_{1}$ and $t_{2}$ respectively, where $t_{2}>t_{1}$. The generation time, $g$, in terms of the specific growth rate constant is defincd as:

$$
g=\frac{\ln 2}{\mu}=\frac{0.693}{\mu}
$$

Doublings per unit time, $k$, in terms of the specific growth rate constant is defined as follows:

$$
l=\frac{\mu}{\ln 2}=\frac{\mu}{0.693}
$$




\section{APPENDIX B}

THE DETERMINATION OF STOICHIOMETRIES FOR MONONUCLEAR METAL-LIGAND COMPI_EXES

a: $1: n$ complexes only; parenthesises indicate nolar concentrations.

The formation of a $1: n$ metal-ligand complex occurs as follows:

$$
\mathrm{M}^{++}+\mathrm{nH}_{\mathrm{X}} \mathrm{L} \& \mathrm{ML}_{n}+\mathrm{nxH^{+ }}
$$

with the conditional stability constant defined as follows:

$$
K_{e}:=\frac{*_{K}(i-\alpha)}{\left(H^{+}\right)^{n x}}=\left(M_{n}\right),\left(\left(M^{+++}\right)\left(\left(H_{x} L^{L}\right)+\left(H_{x-1} L_{-}\right)+\ldots . .\left(I_{n}\right)\right)\right)
$$

where $n$ is the number of ligands associated during the formation of the metal-ligand complex, $x$ is the number of protons fully associated to the complex, $(1-\alpha)$ is the unionized fraction of the Iigand, $\left(i^{++}\right)$is the free metal, and $l: 1 L_{n}$ is the metal-ligand complex of stoichiometry $n$. The mass balance equation for metal is as follows:

$$
M_{t}=\left(M^{++}\right) z+\left(M L_{n}\right)
$$

where $\left(i^{++}\right) z$ is defined as the sum of all inorganic metal complexes and $z$ is defined in Appendix D. Dividing equation 3 by $\left(M^{++}\right)$, we have the following relationship:

$$
M_{t} /\left(M^{++}\right)=z+\left(\left(M L_{n}\right) /\left(M^{++}\right)\right)
$$

Substituting equation 2 for metal-ligand complex, (Mil ${ }_{n}$ ), we have the following relationship: 


$$
H_{t} /\left(M^{++}\right)=z+K_{e}\left(\left(H_{x} L\right)+\left(H_{x-1} L\right)+\ldots+(L)\right)
$$

Rearranging equation 5, complexed metal divided by free metal is defined as follows:

$$
\left(m_{t}-\left(M^{++}\right) z\right) /\left(M^{++}\right)=K_{e}\left(\left(H_{x} L\right)+\left(H_{x-1} L\right)+\ldots+(L)\right)
$$

Under Shubert's conditions, where there is very little metal present in relation to Iigand, unbound ligand is about equal to the total ligand concentration in the system:

$$
L_{t}^{n}=\left(\left(H_{x} L\right)+\left(H_{x-1} L\right)+\ldots+(L)\right)
$$

Thus under Shubert's condition the conditional stability constant is equal to the following relationship:

$$
K_{e}=\left(M_{t}-\left(M^{++}\right) z\right) /\left(M^{++}\right) L_{t}^{n}
$$

$K_{e}$ is equal to $S_{n}$ as defined in Appendix $E$, for multiligand systems. Thus, equation 8 transforms into the following relationship:

$$
\left(M_{t}-\left(M^{++}\right) z\right) /\left(M^{++}\right)=S_{n} L_{t}^{n}
$$

If a plot of $M_{t}-\left(M^{++}\right) z /\left(M^{++}\right)$versus $L_{t}^{n}$ yields a linear relationship, then $1: n$ complexes are established for the solution, where the slope is equal to $S_{n}$ and the $y$-intercept is 0 .

b. $1: n$ and $1: p$ metal-ligand complexes mononuclear system), assuming $P>n$.

The following metal-ligand equilibria with their formation constants are given as follows:

$$
M^{++}+\mathrm{nH}_{x} \mathrm{~L}_{\leftarrow} \rightarrow M L_{n}+n \times H^{+}
$$




$$
\begin{aligned}
& K_{n}=\frac{*_{n}(1-\alpha)}{\left(H^{+}\right)^{n x}}=\frac{\left(M L_{n}\right)}{\left(M^{++}\right)\left(\left(H_{x} L\right)+\left(H_{n-1} L\right)+\ldots+(L)\right)^{n}} \\
& \mathrm{M}^{++}+\mathrm{pH}_{\mathrm{x}} \mathrm{L} \rightarrow \mathrm{HL}_{\mathrm{p}}+\mathrm{pxH}^{+} \\
& K_{p}=\frac{*_{p}(1-\alpha)}{\left(H^{+}\right)^{p x}}=\frac{\left(M L_{L}\right)}{\left(M^{++}\right)\left(\left(H_{x} L\right)+\left(H_{n-1} L\right)+\ldots+(L)\right)^{p}}
\end{aligned}
$$

Where $n$ and $p$ are the number of ligands associated to the metal, $x$ is the number of protons fully associated to the ligand, $K_{n}$ and $K_{p}$ are the conditional stability products for the formation of $\left(M L_{n}\right)$ and $\left(M L_{p}\right)$ complexes. The mass balance for total metal is as follows:

$$
M_{t}=\left(M^{++}\right) z+\left(M L_{n}\right)+\left(M L_{p}\right)
$$

Dividing equation 14 by $\left(\mathrm{M}^{++}\right)$we have the following relationship:

$$
M_{t} /\left(M^{++}\right)=z+\left(\left(M L_{n}\right) /\left(M^{++}\right)\right)+\left(\left(M L_{p}\right) /\left(M^{++}\right)\right)
$$

Substituting equations 11 and 13 for $\left(M L_{n}\right)$ and $\left(M L_{p}\right)$ and assuming Shubert's condition so that unbound ligand equals the total Iigand concentration, as seen in equation 7 , the following relationship is established:

$$
M_{t} /\left(M^{++}\right)=z+K_{n}\left(L_{t}\right)^{n}+K_{p}\left(L_{t}\right)^{p}
$$

Rearranging equation 16 we have the following relationship:

$$
\left(M_{t}-\left(M^{++}\right) z\right) /\left(M^{++}\right)\left(L_{t}\right)^{n}=K_{n}+K_{p}\left(L_{t}\right)^{p-n}
$$

As defined in Appendix $E, K_{n}$ and $K_{p}$ are equal to $S_{n}$ and $S_{p}$, thus equation 17 transforms into the following equation:

$$
\left(M_{t}-\left(M^{++}\right)_{z}\right) /\left(\left(M^{++}\right)\left(L_{t}\right)^{n}\right)=s_{n}+s_{p}\left(L_{\dot{\tau}}\right)^{p-n}
$$


A plot of $\left.\left(M_{t}-\left(M 1^{++}\right) z\right) /(M)^{++}\right)\left(L_{t}\right)^{n}$ versus $\left(L_{t}\right)^{p-n}$ will establish $1: n$ and $1: p$ complexes in the syster. The true stoichiometries are established if a linear relationship exists. The slope equals $s_{p}$ and the $y$-intercept $s_{n}$. 
APPENDIX C

DERIVATION OF A SCATCHARD PLOT: A COMPLEX HITH ONE METAL AND ONE LIGAND

The data for these plots are obtained from copper titrations at a fixed $\mathrm{pH}$ and total ligand concentration. The association

of a copper-ligand complex is as follows:

$$
\mathrm{Cu}^{++}+\mathrm{H}_{x} \mathrm{~L} \rightarrow \mathrm{CuL}+\mathrm{XH}^{+}
$$

where the conditional stability constant is defined as follows:

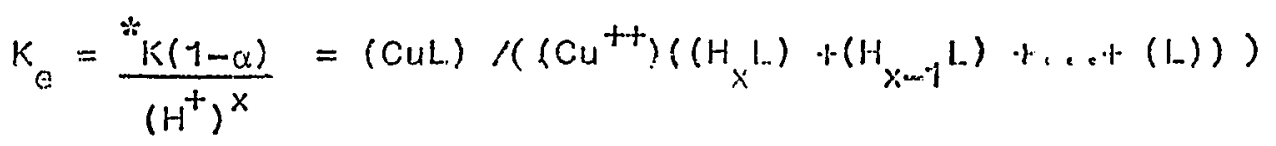

where $n$. is the number of ligands associated during the fornation of the copper-ligand complex, $x$ is the number of protons fully associated to the complex, $(1-\alpha)$ is the unionized fraction of the ligand, $\left(\mathrm{Cu}^{++}\right)$is the free copper concentration, and (CuL) is the copper-ligand complex. The mass balance equation for total ligand is as follows:

$$
\left\{L_{t}\right\} / M H=\left(H_{x} L\right)+\left(H_{x-1} L\right)+\ldots+(L)+(C u L)
$$

$\left\{L_{t}\right\}$ is the total ligand concentration in grams per liter and MW is the molecular weight of the ligand. Substituting equation 3 into 2 for (CUL) we have the following relationship:

$$
K_{e}=\frac{(C u L)}{\left(C u^{+f}\right)\left(\left\{L_{t}\right\} / M(d-(C u L))\right.}
$$

The mass balance for total copper in the system is: 


$$
c u_{t}=\left(C u^{++}\right) z+(C u L)
$$

where $\left(\mathrm{Cu}^{++}\right) \mathrm{z}$ is defined as the sum of all inorganic metal complexes and $z$ is defined in Appendix D. $\mathrm{Cu}_{t}$ is the total copper concentration. Substituting equation 6 into equation 4 we have the following relationship.

$$
k_{e}=\left(C u_{t}-\left(C u^{++}\right) z\right) /\left(\left(C u^{++}\right) \frac{\left\{L_{t}\right\}}{\text { PNy }}-\left(C u^{++}\right) z\right)
$$

Rearranging equation 6 the following relationship is derived:

$$
\frac{\left(C u_{t}-\left(C u^{++}\right) z\right)}{\left(C u^{++}\right)}=K_{e}\left\{\frac{\left\{L_{t}\right\}}{M !}-\left(C u_{t}-\left(C u^{++}\right) z\right)\right\}
$$

Dividing both sides of the equation by $\left(L_{i}\right)$, the total ligand concentration, the Scatchard form of the equation is derived:

$$
\frac{\left(C u_{t}-\left(C u^{++}\right) z\right)}{\left(C u^{++}\right)\left\{L_{t}\right\}}=k_{e} \frac{1}{M ! t}-\frac{\left(C u_{t}-\left(C u^{++t}\right) z\right)}{\left\{L_{t}\right\}}
$$

$$
\left(\mathrm{Cu} u_{t}-\left(\mathrm{Cu} u^{++}\right) z\right) /\left(C u^{++}\right)\left\{L_{t}\right\} \text { is plotted against }\left(C u_{t}-\left(C u^{++}\right) z\right) /\left\{L_{t}\right\}
$$

If a linear relationship can be obtained from this plot then, the absolute value of the slope is the conditional stability constant for (CuL) and the $y$-intercept is the value of the conditional stability constant divicied by the average molecular weight of the ligand. 
APPENDIX D

THE CALCULATION OF COPPER HYDROXIDE AND COPPER CAREONATE CONCENTRATIONS AS A FUNCTXON OF PH AND PCU

a. COPPER HYDROXIDE COMPLEXES

Copper hydrolysis equilibria at $25 \mathrm{C}(I=0)$ with the appropiate constants are listed as follows:

$$
\begin{aligned}
& \mathrm{Cu}^{++}+\mathrm{H}_{2} \mathrm{O} \gtrless \mathrm{CuOH}^{+}+\mathrm{H}^{+} \\
& *_{K_{1}}=\left(\mathrm{CuOH}^{+}\right)\left(\mathrm{H}^{+}\right) /\left(\mathrm{Cu}^{++t}\right)=10^{-7.3} \\
& 2 \mathrm{Cu}^{++}+2 \mathrm{H}_{2} \mathrm{O} \div \mathrm{Cu}_{2}(\mathrm{OH})_{2}^{2+}+\mathrm{ZH}^{+} \\
& { }^{*} \beta_{22}=\left(\mathrm{Cu}_{2}(\mathrm{OH})_{2}^{2+}\right)\left(\mathrm{H}^{+}\right) /\left(\mathrm{Cu}^{++}\right)^{2}=10^{-10.95} \\
& \mathrm{Cu}^{++}+2 \mathrm{H}_{2} \mathrm{O} \gtrless \mathrm{Cu}(\mathrm{OH})_{2}(\mathrm{aq})+2 \mathrm{H}^{+} \\
& { }^{*} \mathrm{~F}_{2}=\mathrm{Cu}(\mathrm{OH})_{2}(\mathrm{aq})\left(\mathrm{H}^{+}\right)^{2} /\left(\mathrm{Cu}^{++}\right)=10^{-15.2} \\
& \mathrm{Cu}^{++}+3 \mathrm{H}_{2} \mathrm{O}+\mathrm{Cu}(\mathrm{OH})_{3}^{-}+3 \mathrm{H}^{+} \\
& { }^{*} \beta_{3}=\left(\mathrm{Cu}(\mathrm{OH})_{3}^{-}\right)\left(\mathrm{H}^{+}\right)^{3},\left(\mathrm{Cu}^{++}\right)=10^{-26.3} \\
& \mathrm{Cu}^{++}+\Delta_{2} \mathrm{H}_{2} \mathrm{O} \rightarrow \mathrm{Cu}(\mathrm{OH})_{4}^{2-}+4 \mathrm{H}^{+} \\
& *_{\beta_{4}}=\left(\mathrm{Cu}(\mathrm{OH})_{4}^{2-} \mathrm{KH}^{+}\right)^{4},\left(\mathrm{Cu}^{++}\right)=10^{-39.4}
\end{aligned}
$$

VaIues for copper hydrolysis constants are in Sillen and Martell (1964). AlI hydroxide concentrations are a function of $\mathrm{pH}$ and $\left(\mathrm{Cu}^{++}\right)$. Rearranging equations $2,4,6,8,10$ we have the following relationships:

$$
\begin{aligned}
& (\mathrm{CuOH})^{++}=\left(10^{-7.3}\right)\left(\mathrm{Cu}^{++}\right) /\left(\mathrm{H}^{+}\right) \\
& \left(\mathrm{Cu}_{2}(\mathrm{OH})_{2}^{2+}(\mathrm{aq})\right)=\left(10^{-10.95}\right)\left(\mathrm{Cu}^{++}\right)^{2} /\left(\mathrm{H}^{+}\right)^{2} \\
& \left(\mathrm{Cu}(\mathrm{OH})_{2}(\mathrm{aq})\right)=\left(10^{-15.2}\right)\left(\mathrm{Cu}^{++}\right) /\left(\mathrm{H}^{+}\right)^{2}
\end{aligned}
$$




$$
\begin{aligned}
& \left(\mathrm{Cu}(\mathrm{OH})_{3}^{-}\right)=\left(10^{-26.3}\right)\left(\mathrm{Cu}^{++}\right) /\left(\mathrm{H}^{+}\right)^{3} \\
& \left(\mathrm{Cu}(\mathrm{OH})_{4}^{2-}\right)=\left(10^{-39.4}\right)\left(\mathrm{Cu}^{++}\right) /\left(\mathrm{H}^{+}\right)^{4}
\end{aligned}
$$

\section{b. COPPER CARBONATE COMPLEXES}

In a system open to the atmosphere, the concentration of coppercarbonate complexes are based on the unbound copper concentration, $\left(\mathrm{Cu}^{+t}\right)$, and the avaiable free carbonate concentration. The concentration of carbonate and bicarbonate ions are defined as follows:

$$
\begin{aligned}
& \left(\mathrm{CO}^{2-}\right)=\mathrm{K}_{1} \mathrm{~K}_{2} \mathrm{~K}_{\mathrm{h}} \mathrm{pCO}_{2} /\left(\mathrm{H}^{+}\right)^{2}=10^{-21.55+2 \mathrm{pH}} \\
& \left(\mathrm{HCO}_{3}^{-}\right)=K_{1} \mathrm{~K}_{h} \mathrm{pCO}_{2} /\left(\mathrm{H}^{+}\right)=10^{-11.3}+\mathrm{pH}
\end{aligned}
$$

where the following constants are defined as:

$$
\begin{aligned}
& K_{1}=\left(\mathrm{H}^{+}\right)\left(\mathrm{HCO}_{3}^{-}\right) /\left(\mathrm{H}_{2} \mathrm{CO}_{3}\right)=10^{-0.3} \\
& K_{2}=\left(\mathrm{H}^{+}\right)\left(\mathrm{CO}_{3}^{2-}\right) /\left(\mathrm{HCO}_{3}^{-}\right)=10^{-10.25} \\
& K_{h}=\mathrm{CO}_{2}(\mathrm{ag}) / \mathrm{CO}_{2}(\mathrm{~g}) / \mathrm{RT}=10^{-1.5} \\
& \mathrm{pCO}_{2}=10^{-3.5}
\end{aligned}
$$

where $R$ is the gas constant, $T$ is the absolute temperature, and $\mathrm{PCO}_{2}$ is the partial pressure of $\mathrm{CO}_{2}$ in the atmosphere. The formation of $\mathrm{Cu}\left(\mathrm{CO}_{3}\right)$ occurs as follows:

$$
\mathrm{Cu}^{++}+\mathrm{CO}_{3}^{2-} \underset{\gtrless}{2} \mathrm{CuCO}_{3}(\mathrm{aq})
$$

The copper carbonate formation constant is defined as follows:

$$
\mathrm{K}_{\mathrm{CuCO}_{3}}=\left(\mathrm{CuCO}_{3}\right)(\mathrm{aq}) /\left(\mathrm{Cu}^{++}\right)\left(\mathrm{CO}_{3}^{2-}\right)=10^{6.77}
$$

Thus, the concentration of $\left(\mathrm{CuCO}_{3}\right)(\mathrm{aq})$ is defined as follows:

$$
\left(\mathrm{CuCO}_{3}\right)(\mathrm{aq})=\mathrm{K}_{\mathrm{CuCO}_{3}}\left(\mathrm{Cu}^{++}\right)\left(\mathrm{CO}_{3}^{2-}\right)
$$


Substituting equation 16 for the carbonate concentration into equation 24 , we have the following relationship:

$$
\left(\mathrm{CuCO}_{3}{ }^{2-}\right)=\mathrm{K}_{\mathrm{CuCO}_{3}}\left(\mathrm{Cu}^{++}\right) \mathrm{K}_{1} \mathrm{~K}_{2} \mathrm{~K}_{\mathrm{h}} \mathrm{pCO}_{2} /\left(\mathrm{H}^{++}\right)^{2}
$$

Thus the copper carbonate concentration is equal to the following:

$$
\left(\mathrm{CuCO}_{3}\right)(\mathrm{aq})=10^{-14.78+2 \mathrm{pH}}
$$

The formation of $\mathrm{Cu}\left(\mathrm{CO}_{3}\right)_{2}$ occurs as follows:

$$
\left.\mathrm{Cu}^{+++}+2 \mathrm{CO}_{3}^{2-} \rightarrow \mathrm{Cu}_{3} \mathrm{CO}_{3}\right)_{2}^{(\mathrm{aq})}
$$

with the copper carbonate formation constant defined as follows:

$$
K_{\mathrm{Cu}\left(\mathrm{CO}_{3}\right)_{2}}=\left(\mathrm{Cu}\left(\mathrm{CO}_{3}\right)_{2}(\mathrm{aq})\right) /\left(\mathrm{Cu}^{++}\right)\left(\mathrm{CO}_{3}^{2-}\right)^{2}=10^{10.01}
$$

Thus, the concentration of this complex is equal to:

$$
\left(\mathrm{Cu}\left(\mathrm{CO}_{3}\right)_{2}(\mathrm{aq})=\left(\mathrm{Cu}{ }^{++}\right) \mathrm{K}_{\mathrm{Cu}}\left(\mathrm{CO}_{3}\right)_{2}\left(\mathrm{CO}_{3}{ }^{2-}\right)^{2}\right.
$$

Substituting equation 16 for the carbonate ion concentration into equation 29, we have the following relationship:

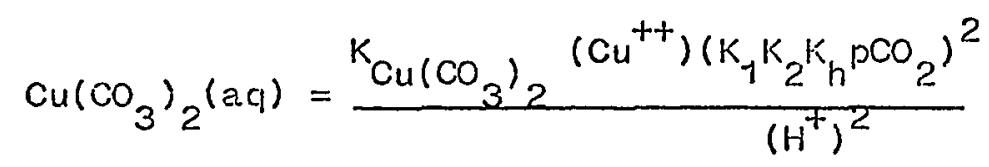

Thus this complex is equal to:

$$
\mathrm{Cu}\left(\mathrm{CO}_{3}\right)_{2}(\mathrm{aq})=10^{-33.09+4 \mathrm{pH}}
$$

The constants for copper carbonate complexes are in Sillén and MarteIl (1964).

\section{c. DEFINITION OF $z$}

Throughout all calculations involving conditional stability constants, copper hydroxide and copper carbonate complexation has been accounted-for in calculations so that organic complexation 
represents the only complexed copper in the systern. This complexed copper is defined as follows:

$$
\mathrm{Cu}(L 1)+\mathrm{Cu}(L 2)+\ldots+\mathrm{Cu}(L N)=\mathrm{Cu}_{t}-\left(\mathrm{Cu}^{++}\right) \mathrm{z}
$$

where $z$ is defined throughout the text as follows:

$$
\begin{aligned}
& \mathrm{z}=\frac{1+\left(\mathrm{CuOH}_{.}^{+}\right)+\left(\mathrm{Cu}_{2}\left(\mathrm{OH}_{2}^{2+}\right)+\left(\mathrm{Cu}(\mathrm{OH})_{2}(\mathrm{aq})\right)+\left(\mathrm{Cu}(\mathrm{OH})_{3}^{-}\right)+\right.}{\left(\mathrm{Cu}^{++}\right)} \\
& \frac{\left(\mathrm{Cu}(\mathrm{OH})_{4}^{2-}\right)+\left(\mathrm{CuCO}_{3}^{+}\right)+\left({\left.\mathrm{Cu}\left(\mathrm{CO}_{3}\right)_{2}\right)}_{\left(\mathrm{Cu}^{++}\right)}\right.}{}
\end{aligned}
$$

As a function of $\mathrm{pH}$ and $\left(\mathrm{Cu}^{++}\right), \mathrm{z}$ is defined in the following relationship employing equations $11,12,13,14,15,26,31$ :

$$
\begin{aligned}
& z=1+\left(10^{-7.3}\right) /\left(H^{+}\right)+\left(10^{-10.95}\right)\left(\mathrm{Cu}^{++}\right) /\left(\mathrm{H}^{+}\right)^{2}+\left(10^{-15.2}\right) /\left(\mathrm{H}^{+}\right)^{2} \\
& +\left(10^{-26.3}\right) /\left(\mathrm{H}^{+}\right)^{3}+\left(10^{-39.4}\right) /\left(\mathrm{H}^{+}\right)^{4}+\left(10^{-14.87+2 \mathrm{pH}}\right) \\
& +\left(10^{-33.1+4 \mathrm{pH})}\right.
\end{aligned}
$$


THE CALCULATION OF A CONDITIONAL STAEILITY CONSTANT AS A FUNCTION OF $\mathrm{pH}$ for $1: \mathrm{n}$ NiETAL-LIGAND COMPLEXES

Derived in Maccarthy and Smith ( 1979$)$, the conditional stability function, $s_{n}$, is defined as follows for a mixture of ligands:

$$
S_{n}=\frac{T N\left(B(L 1)_{b 1}(L 2)_{b 2} \ldots(L N)_{b N}\right)}{\left.(B)^{++}\right)\left(_{\sum_{i}}\left(L_{i}\right)^{n}\right.}
$$

where $T N$ is the total number of complexes of stoichiometry $1: N$, $\left(M^{++}\right)$is the unbound metal species, $N$ is the number of ligand species in the system, $n$ is the stoichiometry of the complexes, bj. is the number of times $L_{i}$ appears in the complex. $S_{n}$ equals $K_{e}$, the conditional stability constant, when there is ninimum competition for ligands or metal (C.L.A.S.P. values). See the discussion section on conditional stability constants for a more detailed discussion of this topic. C.L.A.S.P. values are reached under two conditions, Shubert conditions where there is very little metal in the system, and excess metal conditions. Under Shubert conditions, the total ligand concentration is about equal to the total concentration of unbound ligand in the system:

$$
L_{t}=\pi_{i=1}^{N}\left(L_{i}\right)
$$


All metal-ligand complexes are of very low molarity compared to the unbound ligand species. Under Shubert conditions, $s_{n}$, is modified in the form below for a mixture of ligands of $1: n$ metal-ligand stojchiometries:

$$
s_{n}=\sum^{T N}\left(M^{++}(L 1)_{b 1}(L 2)_{b 2} \cdots(L N)_{b n}\right) /\left(\left(M^{++}\right)\left(L_{t}\right)^{n}\right.
$$

The total metal complexed in the system is as follows:

$$
\sum_{\sum}^{T N}\left(B^{++}(L 1)_{b 1}(L 2)_{b 2} \cdots(L N)_{b n}\right)=\left(M_{t}-\left(M^{+++}\right)\right)
$$

If the metal hydroxide and metal carbonate complexes are excluded from $S_{n}$ then equation 4 is modified to the form:

$$
\sum_{\Sigma}^{T N}\left(M^{++}(L-1)_{b 1}(L 2)_{b 2} \ldots(L N)_{b n}\right)=\left(M_{t}-\left(M^{++}\right) \cdot z\right)
$$

where $z$ is clefined in Appendix D. Substituting equation 5 in this Appendix into equation $3, S_{n}$ j.s defined under Shubert conditions for a mixture of Iignads:

$$
s_{n}=\left(M_{t}-\left(M^{++}\right) z\right) /\left(\left(M^{++}\right)\left(L_{t}\right)^{n}\right)
$$

Thus this C.L.A.S.P. value, $S_{n}$, is obtained from: $(1)$ the total metal in the system, $M_{t},(2)$ the free metal obtained from a metal selective electrode, (3) the $\mathrm{pH}$, and (4) the total concentration of Iigand, $L_{t}$, obtained from the copper complexing capacity experiment. See the discussion section for this calculation. For a mixture of ligands containing $1: 1$ metal-ligand complexes only, $S_{n}$ in equation 6 reduces to the following equation under Shubert conditions:

$$
\left.S_{n}=\left(M_{t}-\left(M^{++}\right) z\right) /\left((M)^{++}\right)\left(L_{t}\right)\right)
$$


Under all total metal and total ligand conditions, the total

unbound ligand species is defined as follows:

$$
\sum_{i=1}^{N}\left(L_{i}\right)^{n}=L_{t}-n_{\sum}^{T N}\left(\left(M^{++}\right)(L 1)_{b 1}(L 2)_{b 2} \ldots(L N)_{b n}\right)
$$

Substituting equation 8 into equation $1, s_{n}$ is defined as follows:

$$
S_{n}=\frac{\left.\sum^{T N}\left((B)^{++}\right)(L Y)_{b 1}(L 2)_{b 2} \ldots(L N)_{b n}\right)}{\left(M^{++}\right)\left(L_{t}-n^{T N}\left(\left(M^{++}\right)(L 1)_{b 1}(L 2)_{b 2} \ldots(L N)_{b n}\right)^{n}\right.}
$$

From the substitution of equation 4 into equation 9 we have the following relationship:

$$
s_{n}=\left(M_{t}-\left(M^{++1}\right) /\left(\left(L_{t}-n\left(M_{t}-\left(M^{++}\right)\right)^{n}\left(M^{++}\right)\right)\right.\right.
$$

Excluding metal-hydroxide and metal-carbonate complexes, $S_{n}$, is ciefined as follows over a wide range of total metal and ligand concentrations:

$$
s_{n}=\left(M_{t}-\left(M^{++}\right) z /\left(\left(L_{t}-n\left(M_{t}-\left(M^{+++}\right)\right)^{n}\left(M^{++}\right)\right)\right.\right.
$$


DETERMINATION OF CONDITIONAL STAEILITY CONSTANTS FOR NTA AS A FUNCTION OF PH

$$
\begin{aligned}
& \text { Copper-NTA complex is formed by the following association: } \\
& \mathrm{Cu}^{++}+\mathrm{NTA}^{3-} \rightarrow \text { CUNTA }
\end{aligned}
$$

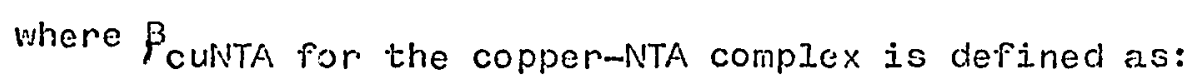

$$
\beta_{\text {CUNTA }}=\left(\text { CUNTA }{ }^{-}\right) /\left(\left(\mathrm{Cu}^{++}\right)\left(\text {NTA }^{3-}\right)\right)
$$

NTA is also found in different protonated fomis, HNTA ${ }^{2-}, \mathrm{H}_{2} \mathrm{NTA}^{-}$, - ${ }_{3}$ MTA with the proportion of each based on PH. The fraction of NTA j.s the non-protomated state is defined as follows:

$$
\alpha=\frac{\left(N T A^{3-}\right)}{\left(\left(H_{3} N T A\right)\left(H_{2} N T A^{-}\right)\left(H N T A^{2-}\right)\left(N T A^{3-}\right)\right.}
$$

The fraction can be calculated from the acid dissocaition consiants of NTA and pH in the following relationship:

$$
\alpha=\left(1+K_{3}^{-1}\left(H^{+}\right)+K_{3}^{-1} K_{2}^{-1}\left(H^{+}\right)^{2}+K_{3}^{-1} K_{2}^{-1} K_{1}^{-1}\left(H^{+}\right)^{3}\right)^{-1}
$$

Where the acid dissociation constants for NTA are as follows:

$$
\begin{aligned}
& K_{1}=\left(H^{+}\right)\left(H_{2} N^{-}\right) /\left(H_{3} N T A\right) \\
& K_{2}=\left(H^{+}\right)\left(H_{N T A^{2-}}\right) /\left(H_{2} N_{T A}^{-}\right) \\
& K_{3}=\left(H^{+}\right)\left(N_{T A}^{3-}\right) /\left(H_{N T A^{2-}}\right)
\end{aligned}
$$

The conditional stability constant for NTA is defined as follows:

$$
K_{e}=\left(\text { CUNTA }^{-}\right) /\left(\mathrm{Cu}^{++}\right)\left(\left(\mathrm{H}_{3} \mathrm{NTA}^{+}\right)+\left(\mathrm{H}_{2} \mathrm{NTA}^{-}\right)+\left(\mathrm{HNTA}^{2-}\right)+\left(\mathrm{NTA}^{3-}\right)\right)
$$

The conditional stability constant, $K_{e}$, relates to $\beta_{\text {cunta }}$ in the 
following relationship:

$$
K_{e}=\beta_{\text {cuNTA }}
$$

If an adiditional protonated form of the copper-ligand complex,

(CuriNTA) is included in the calculation of the conditional stability

constant, then the constant is defined as follows:

$$
K_{e}=\beta_{\text {CUNTA }} \alpha+\beta_{\text {cuHNTA }}\left(H^{+}\right) \alpha
$$

where $\beta_{\text {cuHNTA }}$ for the formation of copper protonated NTA complex

is ciefined as follows:

$$
\beta_{\text {CUHNTA }}=(\text { CUHNTA }) /\left(\left(\mathrm{Cu}^{++}\right)\left(H^{+}\right)\left(N T A^{3-}\right)\right)
$$

